INTERNATIONAL MONETARY FUND
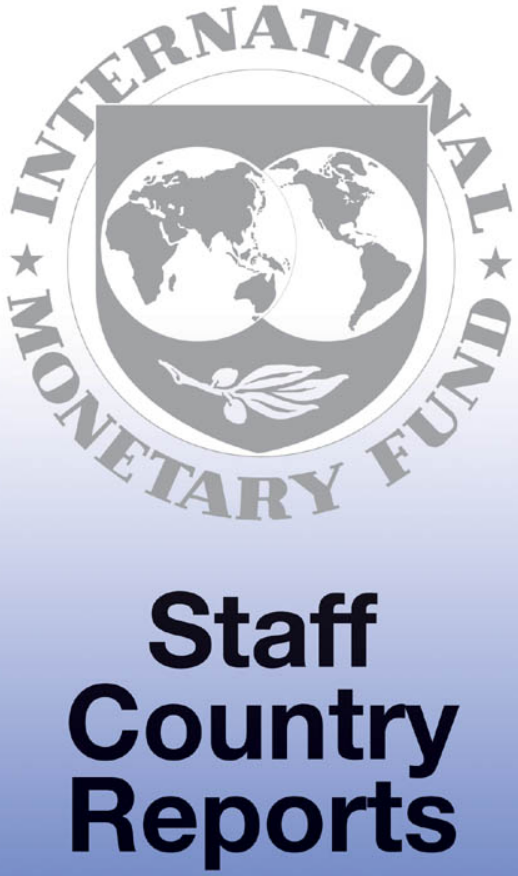


\section{Jordan: 2004 Article IV Consultation and Second Review under the Stand-By Arrangement-Staff Report; Staff Statement; Public Information Notice and Press Release on the Executive Board Discussion; and Statement by the Executive Director for Jordan}

Under Article IV of the IMF's Articles of Agreement, the IMF holds bilateral discussions with members, usually every year. In the context of a combined discussion of the 2004 Article IV consultation with Jordan and second review under the Stand-By Arrangement, the following documents have been released and are included in this package:

- $\quad$ the staff report for the 2004 Article IV consultation and the second review under the Stand-By Arrangement, prepared by a staff team of the IMF, following discussions that ended on February 19, 2004 with the officials of Jordan on economic developments and policies. Based on information available at the time of these discussions, the staff report was completed on March 17, 2004. The views expressed in the staff report are those of the staff team and do not necessarily reflect the views of the Executive Board of the IMF.

a staff statement of April 2, 2004 updating information on recent developments.

a Public Information Notice (PIN) and Press Release summarizing the views of the Executive Board as expressed during its April 2, 2004 discussion of the staff report on issues related to the Article IV consultation and the IMF arrangement, respectively.

- $\quad$ a statement by the Executive Director for Jordan.

The document listed below have been or will be separately released.

Selected Issues Paper and Statistical Appendix

The policy of publication of staff reports and other documents allows for the deletion of market-sensitive information.

To assist the IMF in evaluating the publication policy, reader comments are invited and may be sent by e-mail to publicationpolicy@imf.org.

Copies of this report are available to the public from

International Monetary Fund • Publication Services

$70019^{\text {th }}$ Street, N.W. • Washington, D.C. 20431

Telephone: (202) 623-7430 • Telefax: (202) 623-7201

E-mail: publications@imf.org • Internet: http://www.imf.org

Price: $\$ 15.00$ a copy

International Monetary Fund

Washington, D.C. 
This page intentionally left blank

CInternational Monetary Fund. Not for Redistribution 


\section{INTERNATIONAL MONETARY FUND}

\section{JORDAN \\ Staff Report for the 2004 Article IV Consultation, Second Review under
the Stand-By Arrangement, and Request for Waiver of Applicability}

Prepared by Middle East and Central Asia and

Policy Development and Review Departments

Approved by Mohsin S. Khan and Martin Fetherston

March 17, 2004

- Discussions on the Article IV consultation and the second review under the Stand-By Arrangement (SBA) were held in Amman during October 29-November 12, 2003, and February 8-19, 2004. The staff comprised Messrs. Mansur (head), Mongardini, Poddar, and Rayner (all MCD), Ms. Zakharova (FAD), Mr. Geadah (MFD), and Mr. Feler (PDR). Mr. Shaalan and Mr. Shbikat (all OED) participated in the policy discussions in November 2003 and February 2004, respectively.

- The mission conducted policy discussions with the prime minister, the deputy prime minister, the minister of finance, and the governor of the Central Bank of Jordan (CBJ). It met with the ministers of energy, planning, telecommunications and information technology, and tourism; officials of the Social Security Corporation (SSC) and the privatization commission; and representatives of the business community, academia, and the press. The authorities have recently participated in an FSAP assessment, headed by Mr. Musalem (WB) and Mr. Geadah (MFD). The FSSA is summarized in Section III.C and Box 1. Jordan accepted the obligations of Article VIII, Section 2, 3, and 4 in 1997, and the exchange system remains free of restrictions on payments and transfers for current international transactions.

- The SBA in the amount equivalent to SDR 85.28 million (50 percent of quota) was approved in July 2002. Jordan's outstanding use of Fund resources at end-January 2004 was equivalent to

SDR 279.3 million or 163.8 percent of quota (Appendix I). Following the approval of the SBA, the Paris Club granted an exit rescheduling to Jordan covering obligations on pre-cutoff date debt through 2007. In view of the stronger balance of payments position, the authorities have not used Fund resources after the completion of the first review and plan to treat the remainder of the arrangement as precautionary. The accompanying selected issues paper includes an analysis of the authorities fiscal strategy, a comprehensive debt sustainability analysis, and a chapter on the impact on Jordan of the elimination of quotas under the WTO Agreement on Textiles and Clothing.

- The World Bank is supporting structural reforms with a second Public Sector Reform Loan (PSRL2) in the amount of $\$ 120$ million (Appendix II). The timeliness and coverage of macroeconomic data are generally sufficient for program monitoring (Appendix III).

- The authorities have consented to the publication of the letter of intent and the PIN and will consider publication of the staff report after it is issued to the Executive Board. 


\section{Table of Contents}

List of Acronyms

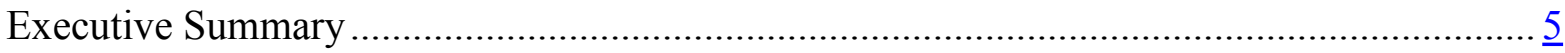

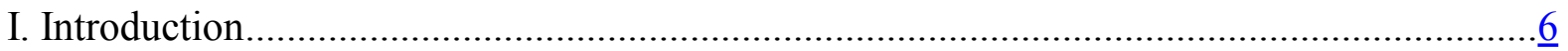

II. Recent Economic Developments....................................................................

III. Article IV Consultation Discussions ................................................................... 14

A. Progress in Fiscal Consolidation ................................................................. $\frac{16}{17}$

B. Tax Policy and Tax Administration Reforms................................................. 17

C. Financial System Vulnerabilities................................................................. $\frac{17}{18}$

D. Sustainability of Recent Gains in the Export Sector ...................................... 18

E. Exchange Rate Policy ........................................................................................ 20

IV. Policy Discussions Related to the Program for 2004 ................................................20

A. Structural Policies ................................................................................. $\frac{21}{2}$

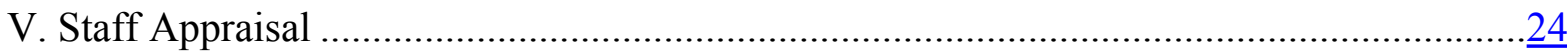

Text Boxes

1. Findings of Financial System Stability Assessment (FSSA) …................................... 19

2. Structural Conditionality.............................................................................. 23

Text Tables

1. Summary Operations of the Consolidated Public Sector, 1999-2003 ............................10

Figures

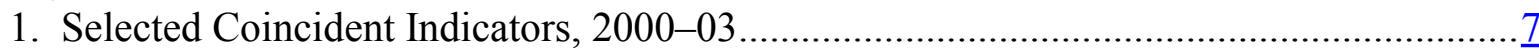

2. Growth in Leading Economic Indicators Index ....................................................... $\underline{8}$

3. Market Capitalizaton of the Amman Stock Exchange .................................................. $\underline{8}$

4. Overall Fiscal Balance .......................................................................................... $\frac{8}{9}$

5. GST and Customs Duties Collection .................................................................... 9

6. International Reserves, Interest Rates, and CD Sales, 1997-2004 .................................11

7. Merchandise Exports, Real and Nominal Effective Exchange Rate Indices .................... $\underline{12}$

8. Annual Growth of Broad Money and Private Sector Credit .........................................13

9. Medium-Term Macroeconomic Outlook, 2002-09 …................................................ $\frac{15}{18}$

10. Jordan and U.S. Yield Curves, End-September 2003 .............................................. 18

Tables

1. Summary of the Macroeconomic Framework, 2000-09 ............................................ 27

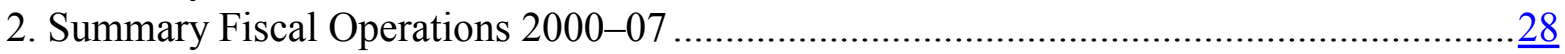




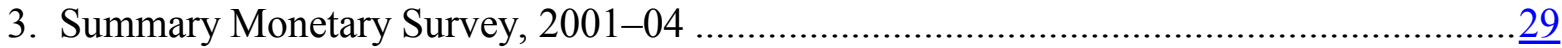

4. Summary Accounts of the Central Bank of Jordan, 2001-04 ........................................ $\underline{30}$

5. Summary Balance of Payments, 2000-09................................................................. $\frac{31}{32}$

6. Total Government and Government-Guaranteed Debt, 2000-09 .................................. $\frac{32}{33}$

7. Medium-term External Debt and Debt Service, 2000-09........................................... $\frac{33}{34}$

8. Indicators of Financial Vulnerability, 2000-04 ........................................................... $\frac{34}{35}$

9. Indicators of Bank Soundness, 1998-2003 ............................................................... $\underline{35}$

10. Indicators of Fund Credit, 2000-10 ................................................................. $\frac{36}{37}$

11. Original and Revised Schedule of Purchases under the Stand-by Arrangement .............. $\underline{37}$

12. Quantitative Performance Criteria and Indicative Targets under the Stand-by

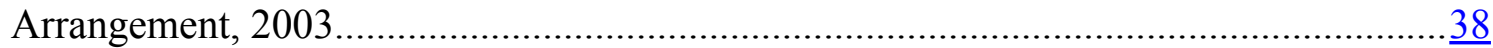

13. Structural Performance Criteria and Benchmarks Under the Stand-By Arrangement, 2000-04..

Appendices

1. Relations With the Fund ...................................................................................... 41

2. World Bank Group Strategy and Operations ..................................................... 44

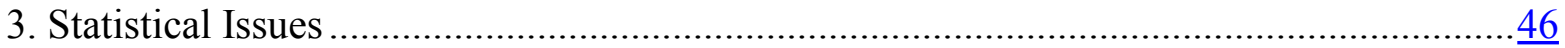

Attachments

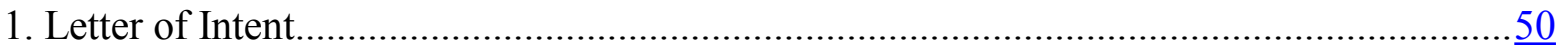




\section{List of Acronyms}

$\begin{array}{ll}\text { APC } & \text { Arab Potash Company } \\ \text { ATC } & \text { World Trade Organization Agreement on Textiles and Clothing } \\ \text { BOP } & \text { Balance of Payments } \\ \text { CAS } & \text { Country Assistance Strategy } \\ \text { CBJ } & \text { Central Bank of Jordan } \\ \text { CD } & \text { Certificate of Deposit } \\ \text { CIRR } & \text { Commercial Interest Rates } \\ \text { CPI } & \text { Consumer Price Index } \\ \text { DOS } & \text { Department of Statistics } \\ \text { FDI } & \text { Foreign Direct Investment } \\ \text { FSAP } & \text { Financial System Stability Assessment } \\ \text { FTA } & \text { Free Trade Agreement } \\ \text { GBL } & \text { General Budgetary Law } \\ \text { GST } & \text { General Sales Tax } \\ \text { HEIS } & \text { Household Expenditure and Income Survey } \\ \text { IAS } & \text { International Accounting Standards } \\ \text { IFC } & \text { International Finance Corporation } \\ \text { IPP } & \text { Independent Power Producer } \\ \text { ISA } & \text { International Standards in Auditing } \\ \text { ITD } & \text { Income Tax Department } \\ \text { JIC } & \text { Jordan Investment Corporation } \\ \text { MEFP } & \text { Memorandum on Economic and Financial Policies } \\ \text { NDA } & \text { Net Domestic Assets } \\ \text { NFA } & \text { Net Foreign Asset } \\ \text { NIR } & \text { Net International Reserves } \\ \text { PPI } & \text { Producer Price Index } \\ \text { PSET } & \text { Plan for Social and Economic Transformation } \\ \text { PSRL } & \text { Public Sector Reform Loan } \\ \text { QIZ } & \text { Qualified Industrial Zones } \\ \text { ROSC } & \text { Report on the Observance of Standards and Codes } \\ \text { SBA } & \text { Stand-by Arrangement } \\ \text { SDDS } & \text { Special Data Dissemination Standard } \\ \text { SME } & \text { Small- and Medium-Sized Enterprises } \\ \text { SSC } & \text { Social Security Corporation } \\ \text { STD } & \text { Sales Tax Department } \\ \text { WEO } & \text { World Economic Outlook } \\ \text { WTO } & \text { World Trade Organization } \\ & \end{array}$




\section{Executive Summary}

Background: Recent economic developments point to performance in line with or exceeding program targets. Real GDP grew by 3.2 percent in 2003, despite the disruption of exports to Iraq. The overall fiscal deficit for 2003 was $1 \frac{1}{2}$ percent of GDP less than programmed, reflecting strong efforts by the government to contain spending in the last two months of 2003. However, the postponement of spending of about 1 percent of GDP to 2004 makes the attainment of the 2004 fiscal deficit target more difficult. The external current account registered a large surplus. As a result, gross usable reserves of the Central Bank of Jordan (CBJ) reached $\$ 4.7$ billion at end-2003, and monetary aggregates expanded rapidly. The Financial System Stability Assessment (FSSA) report highlighted that, while Jordan has currently no substantial financial vulnerabilities, a significant portion of the banking system is undercapitalized. The FSSA points to the need to improve the framework for bank resolution and to deal with undercapitalized banks in a transparent manner.

\section{Article IV discussions: A sustained reduction in the heavy central government debt} burden remains the main challenge for the medium term. The mission helped update the authorities' fiscal strategy with a view to sustaining the reduction in government debt envisaged under the strategy and rebalancing its composition in favor of domestic debt over the medium term. The success of the fiscal strategy hinges mainly on increasing petroleum product prices with a view to fully compensating for the loss of the Iraqi oil grants and further reforms of the tax system and its administration. In particular, the authorities have agreed to further reforms of tax administration along the lines of FAD technical assistance. The mission reviewed the authorities' plans to deal with the undercapitalized banks and underscored the importance of resolving this problem expeditiously. The authorities maintained that the case for a shift to a more flexible regime was not clear cut, and they underscored the vulnerability of public debt to adverse exchange rate movements. They also felt that shifting to a more flexible exchange rate regime was premature at the present time, arguing that the ensuing uncertainty would likely undermine the ongoing, but still fragile, recovery and complicate the already challenging economic policy agenda.

Program discussions: Agreement was reached on the macroframework and the budget for 2004. The authorities have reaffirmed their commitment to raise the price of petroleum products and increase other taxes in April 2004 to achieve the fiscal deficit target of 3.9 percent of GDP, but the postponement of additional spending ( 1 percent of GDP) from 2003 can only be absorbed if additional external grants materialize. The discussions with the CBJ centered on the health of the banking system and the recent strengthening of banking supervision. 


\section{INTRODUCTION}

1. In the attached letter, the Jordanian authorities request completion of the second review under the Stand-By Arrangement (SBA) and a waiver of applicability for endMarch 2004 performance criteria. The attached Memorandum on Economic and Financial Policies (MEFP) describes developments in 2003 and the macroeconomic policies and structural reform agenda for 2004. All 2003 quantitative performance criteria were met by large margins and all structural benchmarks were implemented. Given the stronger-thanexpected balance of payments position, the authorities intend to treat the remainder of the SBA as precautionary. They have also agreed to a Post-Program Monitoring following the completion of the current SBA. The discussions on the second review lasted longer than anticipated, as the authorities needed time to make progress on pension reform.

\section{The election of a new lower house of parliament in June 2003 produced a large} majority supportive of the authorities' reform agenda. Following the election, a new government was formed in October 2003, headed by Prime Minister Al-Fayez, with a mandate to deepen the democratic process, reduce unemployment, and alleviate poverty. The emphasis on macroeconomic stability, the reduction of public debt, and the momentum on structural reforms, is not expected to change under the new government.

\section{The last Article IV consultation was concluded by the Executive Board on}

April 29, 2002. At that time, Directors welcomed the robust economic performance in 2001 and noted that this owed much to the authorities' prudent macroeconomic policies and the solid implementation of structural reforms. They stressed that the peg to the U.S. dollar and the supporting monetary policy had been effective in bringing inflation down to industrial country levels, fostering confidence in the Jordanian dinar. They encouraged further trade liberalization and privatization and called for a sustained increase in the tax effort. The authorities have since eliminated tariffs on industrial inputs, privatized a number of stateowned enterprises, and widened the income and sales tax base and increased certain tax rates.

\section{RECENT ECONOMIC DEVELOPMENTS}

4. Recent economic developments point to a recovery from the disruptions caused by the war in Iraq (MEFP, paragraph 2). Real GDP growth slowed down to 3 percent in the first nine months of 2003, due to the disruption of exports to Iraq and the negative effects of the conflict on tourism and transportation. Economic growth picked up to 3.5 percent in the fourth quarter of 2003, supported by a strong rebound in export growth (Figure 1), particularly from exports to the United States from the Qualified 
Figure 1. Jordan: Selected Coincident Indicators, 2000-03

Real GDP growth in 2003 has been fueled by a recovery of exports in the second half,...

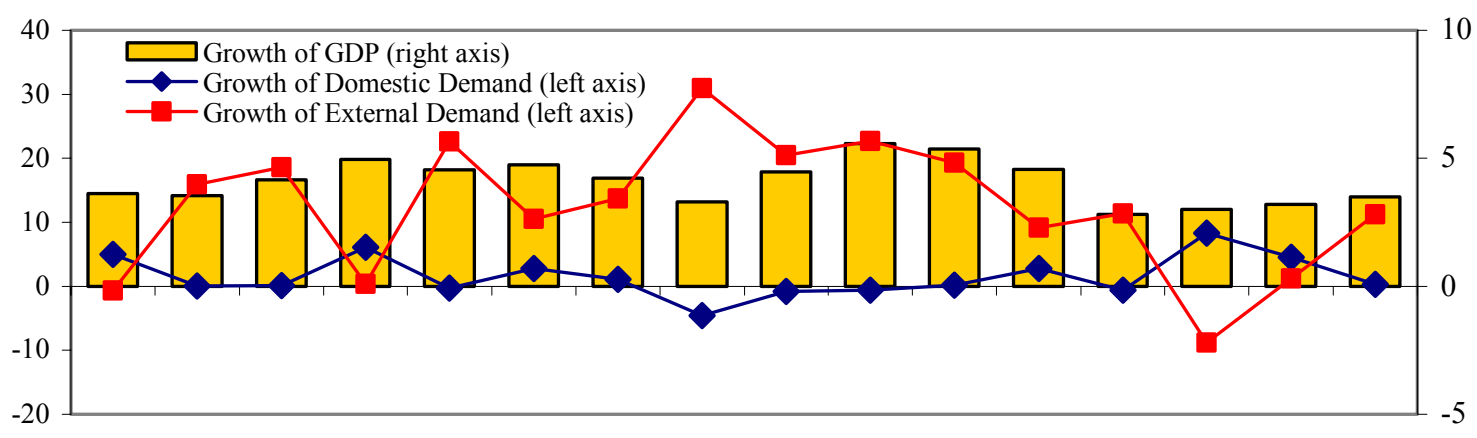

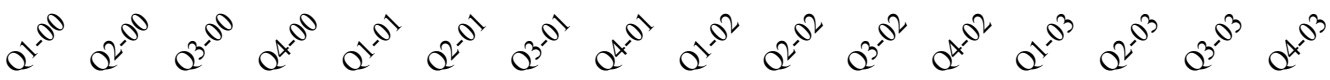

...industrial production has recovered after the war in Iraq, ...

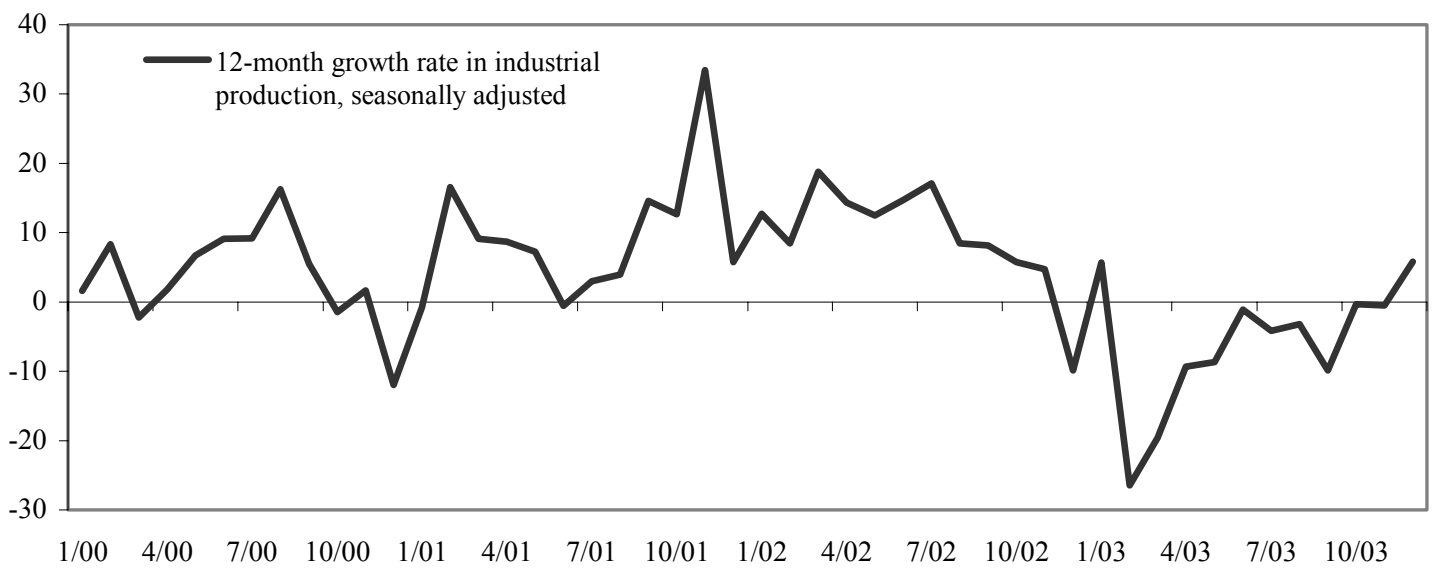

..and import growth has picked up, while credit to the private sector remains subdued.

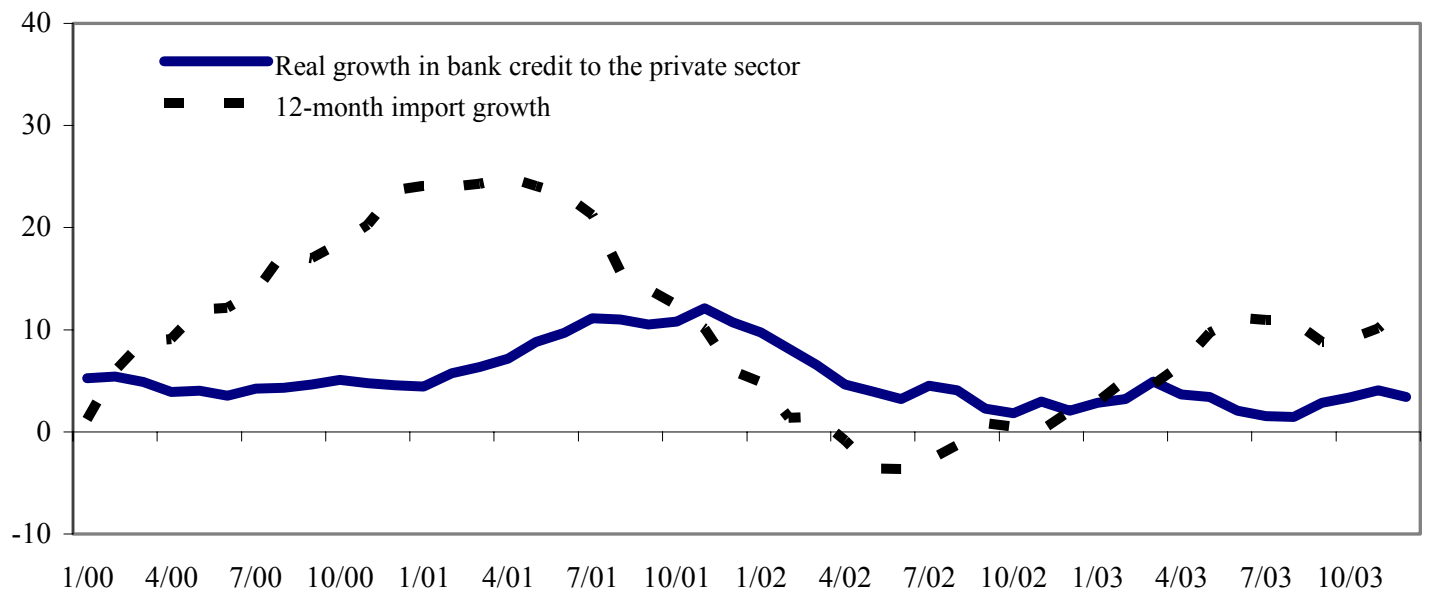

Sources: Jordanian authorities; and Fund staff estimates. 
Industrial Zones (QIZs). ${ }^{1}$ A fiscal stimulus through higher public spending funded through grants also contributed to the recovery in domestic demand. The index of leading indicators of economic activity points to a further recovery through June 2004 (Figure 2). Inflation remains subdued in 2003, despite the depreciation of the Jordanian dinar against the euro and the yen. The Amman Stock Exchange reached record highs in February 2004 and market capitalization increased to 117 percent of GDP in 2003 (Figure 3), but the average price/earnings ratio is in line with the ratio in equity markets in advanced economies. Unemployment, however, remains high at 13.9 percent because of the rapid growth of the labor force and an increased participation rate.

\section{The central government fiscal deficit in}

2003 was lower than programmed, as spending overruns in the areas of defense and security and accelerated capital spending were offset by higher foreign grants and a postponement of payments to 2004 (MEFP, paragraph 3). The overall deficit for 2003 was JD 73 million (1.1 percent of GDP), compared to a target of JD 175 million under the program (Figure 4), as the new government that came into power in October 2003 successfully limited current spending below programmed levels, despite significantly higher military spending reflecting the difficult security situation in the region and some payments to compensate economic sectors affected

Figure 2. Jordan: Growth in Leading Economic Indicator Index

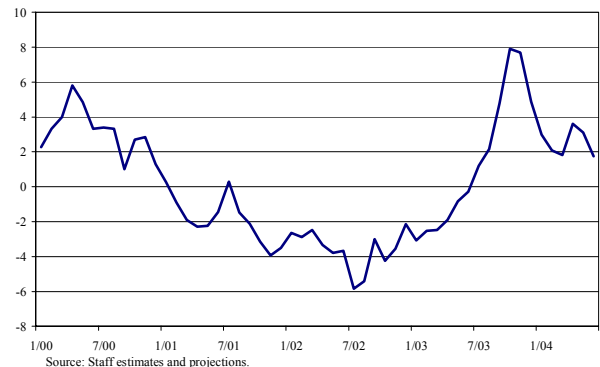

Figure 3. Market Capitalization of the Amman Stock

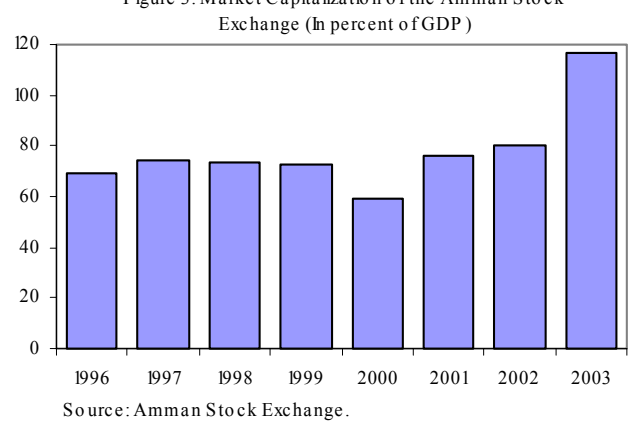

Figure 4. Overall Fiscal Balance (In millions of JD)

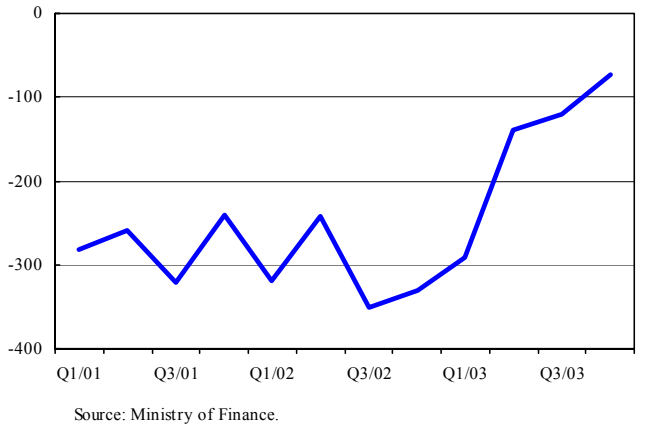

by the war in Iraq. In particular, the authorities implemented spending cuts of JD 70 million committed but not executed by the previous government, issued a special order stopping all expenditure authorizations effected December 15, 2003, and made a strong drive for collection of nontax revenue. The fiscal outturn was also helped by the delay in settling payments to Iraq (1 percent of GDP). ${ }^{2}$ Budgetary revenues were somewhat less than

\footnotetext{
${ }^{1}$ QIZs are industrial parks whose products enjoy duty- and quota-free access to the U.S. market, provided they meet minimum value-added criteria from Israeli and Jordanian inputs.

2 This delay arose from an inability to reconcile the net claims of the Jordanian authorities on Iraq, because of the unsettled situation in Iraq.
} 
programmed, with higher tax revenues only partly offsetting nontax revenue shortfalls. In particular, general sales tax (GST) collections increased strongly, boosted by high import growth and improved revenue administration (Figure 5). Capital spending was boosted by 39 percent in 2003 from the level of spending in the preceding year to offset the slack in the domestic demand in the aftermath of the Iraq war. The Treasury Single Account, a structural benchmark under the program, was implemented on December 1, 2003.
Figure 5. GST and Customs Duties Collections (Four quarter moving average of annual percentage change)

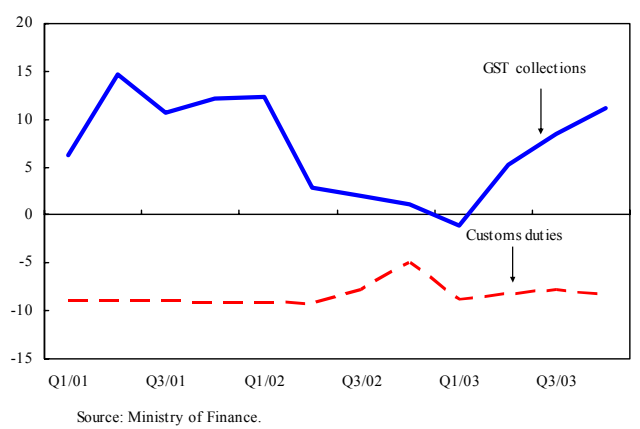

\section{Progress on the public debt front was influenced by heavy valuation losses and} slower GDP growth. Notwithstanding the lower-than-programmed fiscal deficit, government and government-guaranteed debt increased by 1 percentage point to 101.5 percent of GDP at end-2003. This reflected valuation losses equivalent to 6 percentage points of GDP in 2003, associated with the depreciation of the U.S. dollar, to which the Jordan dinar (JD) is pegged, against other major currencies. The deficit and net debt of the consolidated public sector recorded improvements due to the strengthened position of the Social Security Corporation (SSC) and the CBJ. The consolidated public sector fiscal balance registered a surplus of 1.4 percent of GDP in 2003, and the public debt ratio declined by 1 percentage point to 59.7 percent of GDP in 2003 (Text Table 1). In line with its new fiscal funding strategy, the government prepaid its outstanding stock of Par Brady Bonds (\$456 million, including \$185 million of collateral) in December 2003, which was financed through the issuance of domestic bonds and a drawdown of international reserves, thus reducing the external debt burden. The government also signed a debt-for-equity swap with a major bilateral donor in December 2003, resulting in a further reduction in external debt of JD 94 million (1.3 percent of GDP).

\section{The external current account registered a large surplus in 2003, reflecting a} surge in grant receipts and the underlying strength of the balance of payments (MEFP, paragraph 5). Total exports grew by an annual rate of 8.2 percent in 2003, despite the disruption of exports to Iraq during the war and cancellation of export orders in the period preceding the war. Nontraditional exports fared particularly well, including textiles and apparel, mainly to the U.S. market. Re-export activity to Iraq rebounded strongly in the fourth quarter. The strong export performance was offset by faster-than-anticipated import growth (10.8 percent). Tourism receipts started to recover in the third quarter due to an increase of regional visitors and official and business travels related to the situation in Iraq, while remittances grew by 4.3 percent. With grant receipts of almost $\$ 1.3$ billion (13 percent 
Text Table 1. Summary Operations of the Consolidated Public Sector, 1999-2003

(In percent of annual GDP)

\begin{tabular}{|c|c|c|c|c|c|}
\hline & 1999 & 2000 & 2001 & 2002 & 2003 \\
\hline \multicolumn{6}{|l|}{ Consolidated public sector $1 /$} \\
\hline Revenue and grants & 41.3 & 40.7 & 41.4 & 39.9 & 46.2 \\
\hline Expenditure & 42.4 & 43.0 & 42.7 & 43.6 & 44.8 \\
\hline Balance & -1.1 & -2.4 & -1.3 & -3.7 & 1.4 \\
\hline Net debt/assets (-) & 71.5 & 60.2 & 57.9 & 60.7 & 59.7 \\
\hline \multicolumn{6}{|l|}{ Central government } \\
\hline Total revenue and grants & 31.0 & 30.1 & 30.5 & 30.2 & 35.9 \\
\hline Expenditure & 34.5 & 34.8 & 34.2 & 35.2 & 37.0 \\
\hline Balance & -3.5 & -4.7 & -3.7 & -5.0 & -1.1 \\
\hline Net debt/assets (-) & 111.3 & 100.0 & 97.0 & 100.5 & 101.5 \\
\hline \multicolumn{6}{|l|}{ Own-budget agencies } \\
\hline Total revenue and grants & 6.4 & 5.5 & 5.4 & 5.3 & 5.6 \\
\hline Expenditure & 6.1 & 5.7 & 5.8 & 5.9 & 5.8 \\
\hline Balance & 0.3 & -0.2 & -0.5 & -0.6 & -0.2 \\
\hline Net debt/assets (-) 2/ & -0.3 & -1.6 & -0.8 & -0.3 & -0.1 \\
\hline \multicolumn{6}{|l|}{ CBJ } \\
\hline Revenue & 1.9 & 2.6 & 2.6 & 1.4 & 1.9 \\
\hline Expenditure & 2.4 & 2.1 & 2.3 & 1.6 & 1.2 \\
\hline Balance & -0.5 & 0.5 & 0.3 & -0.2 & 0.7 \\
\hline Net debt/assets (-) 2/ & -12.2 & -11.3 & -9.6 & -9.6 & -12.1 \\
\hline \multicolumn{6}{|l|}{ SSC } \\
\hline Revenue & 3.9 & 3.6 & 4.3 & 4.2 & 4.4 \\
\hline Expenditure & 1.3 & 1.4 & 1.8 & 2.2 & 2.4 \\
\hline Balance & 2.7 & 2.2 & 2.7 & 2.1 & 2.0 \\
\hline Net debt/assets (-) & -22.3 & -23.6 & -24.9 & -25.6 & -26.4 \\
\hline \multicolumn{6}{|l|}{ Memorandum item } \\
\hline Public sector net debt, excl. currency in circulation 3/ & 52.3 & 40.2 & 38.8 & 41.8 & 39.1 \\
\hline \multicolumn{6}{|c|}{$\begin{array}{l}\text { Sources: data provided by the Jordanian authorities; and IMF staff estimates. Latest data available. } \\
\text { 1/ Excludes municipalities and some minor public enterprises. Transfers and common debt obligations between sectors } \\
\text { are eliminated. CBJ accounts are on a commitment basis. } \\
\text { 2/ Own-budget agencies domestic banking system debt only. Domestic and external debt of these agencies are captured } \\
\text { under the central government debt. CBJ assets are net foreign assets plus net domestic assets less currency in } \\
\text { circulation. }\end{array}$} \\
\hline
\end{tabular}

of GDP), the external current account surplus was equivalent to 11.1 percent of GDP. Meanwhile, new external borrowing by the public sector was reduced significantly, in line with the new fiscal funding strategy and private capital (net) registered a strong inflow of $\$ 694$ million. As a result, gross official reserves increased by $\$ 1.2$ billion to reach $\$ 4.7$ billion at end-September 2003 (Figure 6), equivalent to about 10 months of prospective import. The real effective exchange rate depreciated by 8.3 percent in 2003 (Figure 7).

8. Monetary aggregates expanded at a strong pace, reflecting the strength of the balance of payments (MEFP, paragraph 6). Broad money grew at an annual rate of 11 percent in 2003, supported by a surge in the net foreign asset (NFA) that was mostly channeled into Jordanian dinar deposits. Private sector credit growth continued to be low, as banks remain cautious and demand for credit was met mainly through utilization of deposits 
Figure 6. Jordan: International Reserves, Interest Rates, and CD Sales, 1997-2004

International reserves continue to surge...

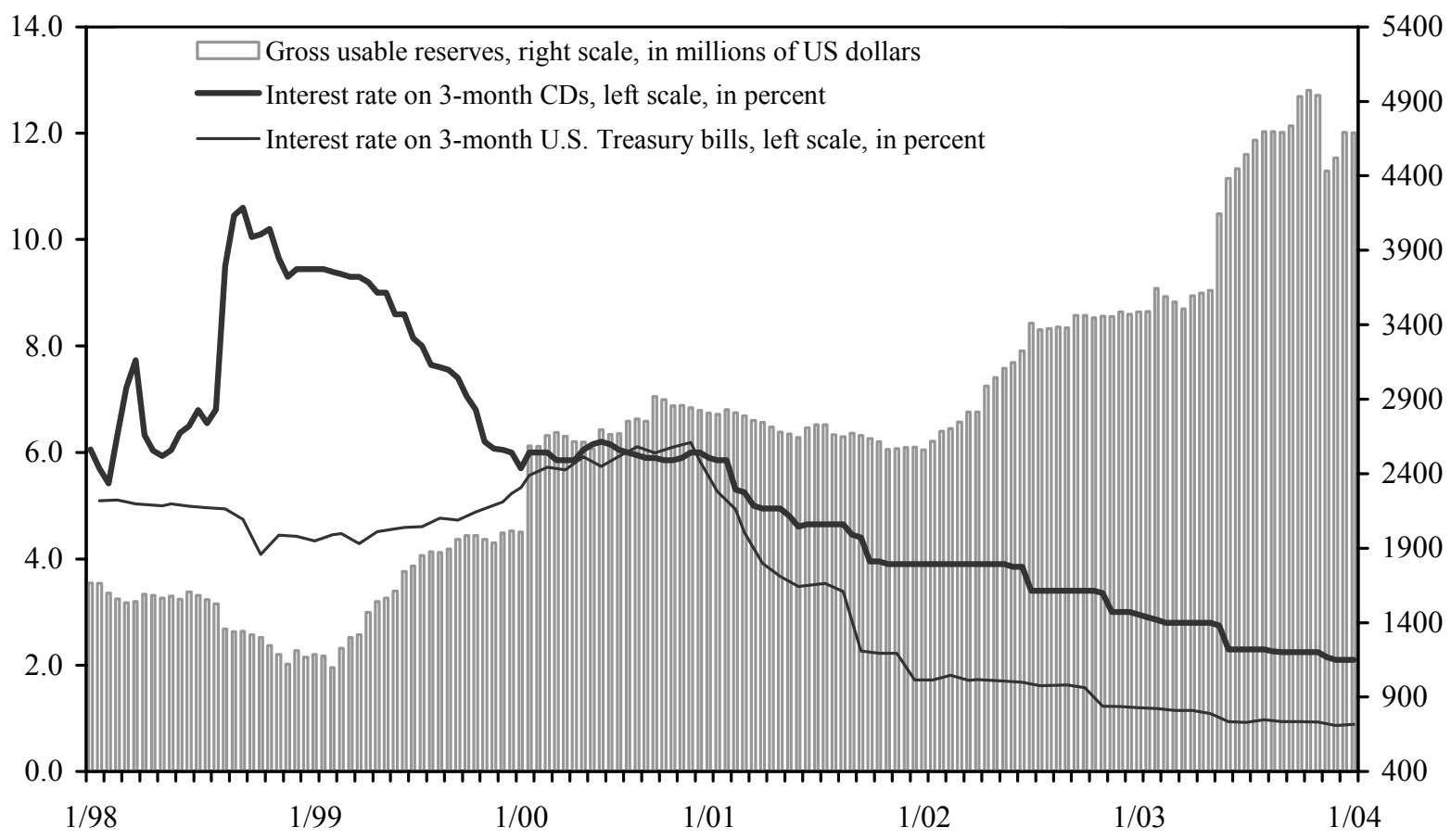

...while interest rates are at historic lows.

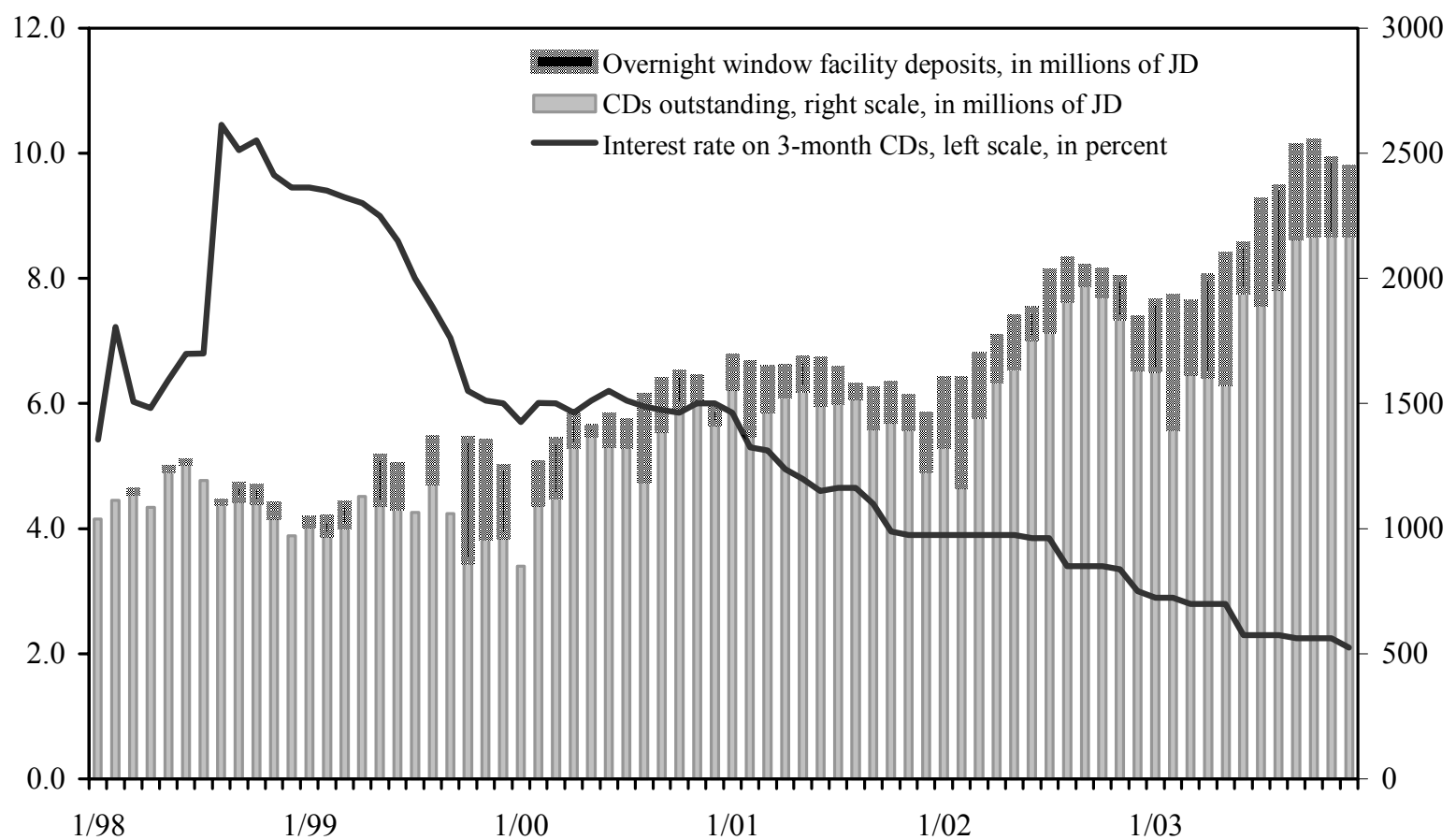

Source: Central Bank of Jordan. 
Figure 7. Jordan: Merchandise Exports, Real and Nominal Effective Exchange Rate Indices January 1999-November 2003, Jan. $1999=100$

Exports rebounded since the war in Iraq, boosted in part by improved competitiveness.

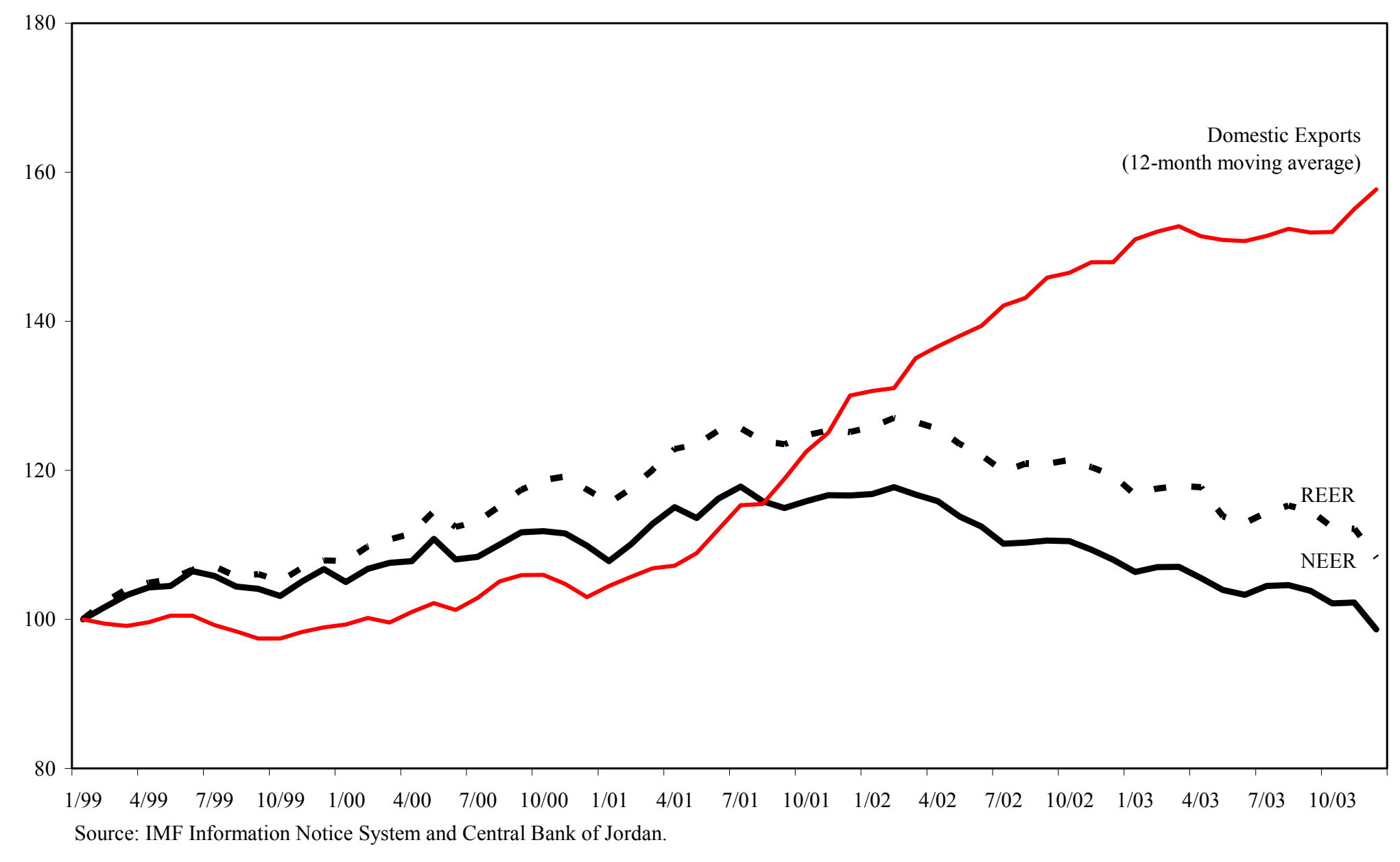


(Figure 8). The large increase in the NFA was only partly sterilized through an increase in bank deposits at the CBJ overnight window facility and bank holdings of CDs. As a result, reserve money grew by an annual rate of 20.7 percent, reflecting the buildup in commercial banks' reserves and a large increase in demand for currency related to cash-based trade with Iraq.

\section{The CBJ restructured one of the banks}

\section{under its temporary administration and strengthened corporate governance (MEFP,} paragraph 7). The restructuring involves the write-off of JD 30 million in the paid-in capital of the bank, the injection of new capital by the original shareholders and the SSC, and a change of the management and the board of the bank. On its part, the CBJ wrote off a JD 40 million interest free loan to the bank in exchange for the payment of the net present value of the loan (JD 9 million) and provided additional interest-free liquidity support. The remaining accumulated losses have been converted into restructuring costs that will be amortized over 10 years. In order to improve capitalization and corporate governance of commercial banks, the CBJ issued regulations in August 2003 to double the minimum capital requirement for banks to JD 40 million over the next four years and introduced a minimum leverage ratio of 6 percent. The CBJ also revamped its banking supervision in January 2004, including through a prompt corrective action framework that stipulates automatic penalties for violations of prudential regulations by banks. Jordan's regulatory and supervisory framework generally observes international standards and codes in banking, payments systems, securities, and insurance, reflecting the efforts to strengthen supervision in recent years.

\section{Structural reforms are progressing as planned (MEFP, paragraph 8). The} government sold half of its holdings (26 percent of total shares) in the Arab Potash Company (APC) along with transfer of management to a Canadian corporation for \$124 million (net of privatization-related spending) in mid-October 2003. A management contract for the handling of the container terminal in the port of Aqaba was signed with a Dutch company in March 2004. The government is also preparing the sale of majority stakes in the electricity generation and distribution companies in the first half of 2004. In the meantime, a new gas pipeline between Egypt and Jordan has been completed by the private sector on a build-ownoperate basis and is expected to be extended to Lebanon, Syria, and Turkey. The government has embarked on a substantial improvement of the education system, with support from an education sector reform loan from the World Bank.

\section{Progress was made in establishing a unified tax administration (MEFP,}

paragraph 10). In line with Fund technical assistance recommendations, a unified revenue department was established in December 2003, encompassing the Income Tax and the Sales Tax Departments. The government appointed a director general in charge of the new department in January 2004, and an integration project directorate was established in February 2004. 


\section{Article IV Consultation Discussions}

\section{Over the last few years, the performance of the Jordanian economy has been}

robust. Real GDP growth has strengthened to about 5 percent in 2002, driven by strong export growth, and the economy has shown strong resilience to the negative effects of the war in Iraq in 2003. The external current account has registered large surpluses, leading to a near doubling of gross usable reserves of the CBJ in the two years through 2003. Fiscal consolidation has continued, albeit at an uneven pace, the GST base has been significantly widened, and the external debt burden is expected to be reduced substantially over the medium term. More importantly, the authorities' steadfast approach to trade liberalization and privatization, as well as a notable decline in red tape, have resulted in a conducive environment for private activity that is increasingly recognized by foreign direct investors.

13. Jordan's medium-term outlook remains positive. Trade liberalization and increased market access have set the stage for strong export-led growth over the mediumterm. ${ }^{3}$ Export growth is expected to continue at about 6-8 percent per year, spurred by the FTA with the United States and the Association Agreement with the EU. Large private sector-led infrastructure projects, including in water, gas, and electricity generation, are likely to boost investment. Plan for Social and Economic Transformation (PSET)-related structural reforms, enhancement of health and educational standards, and poverty alleviation are likely to have a positive impact on growth over the long term. Overall, growth is expected to reach 6 percent over the medium term (Figure 9). At the same time, inflation is likely to remain stable at about 2 percent per year. The external current account is expected to remain in surplus, while gross usable reserves of the CBJ remain at a comfortable level of about 7-8 months of prospective import cover.

\section{The mission engaged the authorities in discussions on a set of broad economic} policy challenges for the medium term. The discussions focused on five main topics: (i) progress in fiscal consolidation and debt reduction, relative to the targets envisaged in the authorities' fiscal strategy and the 2001 public debt law; (ii) tax policy and tax administration reforms; (iii) potential vulnerabilities of the financial system identified by the recent FSAP assessment; (iv) the sustainability of the gains made in the export sector; and (v) exchange rate policy.

\footnotetext{
${ }^{3}$ Jordan's simple average tariff rate is 13 percent with a maximum tariff rate of 30 percent. Jordan's overall trade restrictiveness rating is 5 , due to the exclusive licensing of petroleum products due to be eliminated by 2008 under the WTO agreement.
} 
Figure 9. Jordan: Medium-Term Macroeconomic Outlook, 2002-09

The medium-term outlook remains positive, despite the disruption caused by the war in Iraq.
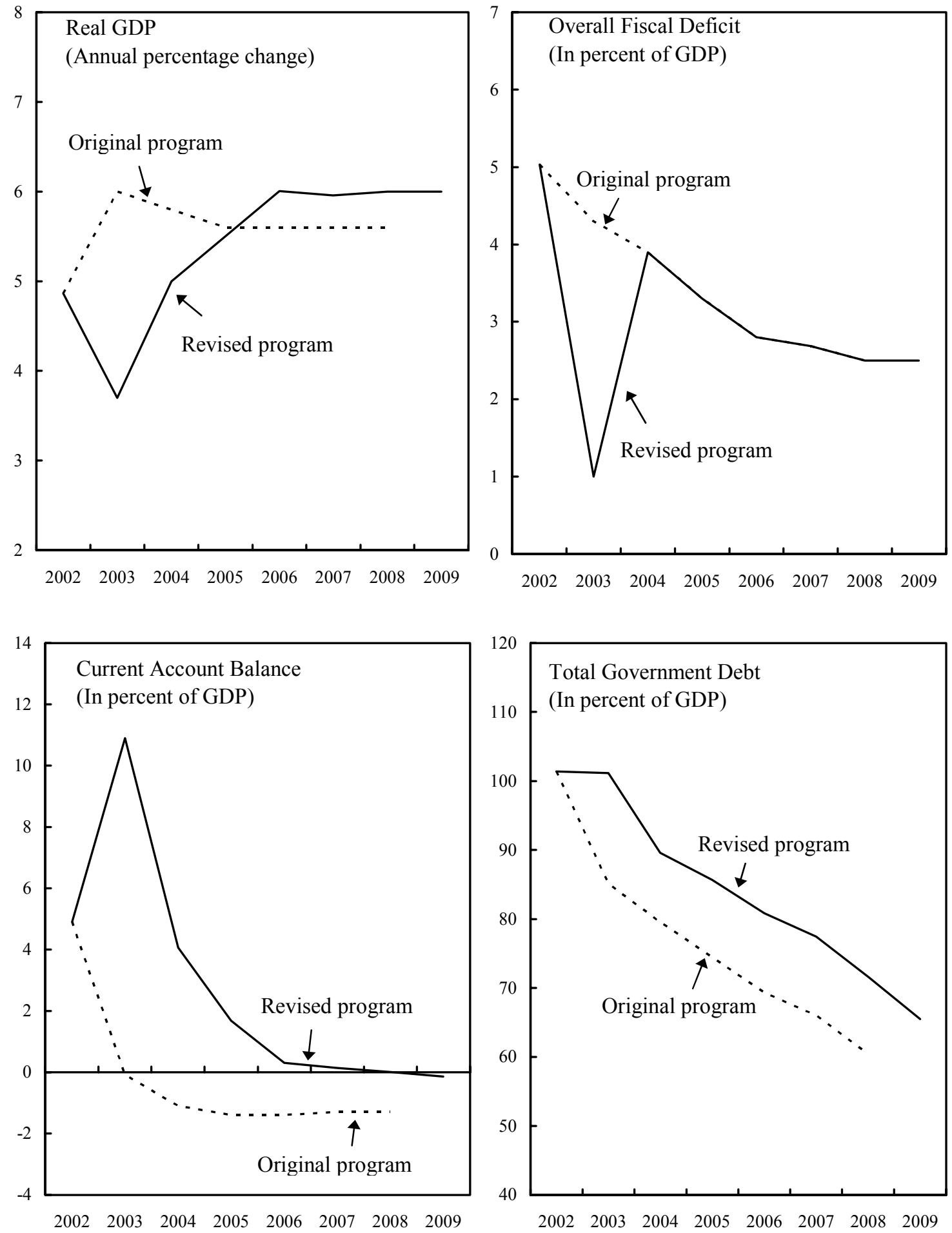

Source: Jordanian authorities and Fund staff estimates and projections. 


\section{A. Progress in Fiscal Consolidation}

\section{Progress in fiscal consolidation and debt reduction has been uneven in recent}

years. The mission helped the authorities update their medium-term fiscal strategy, which remains anchored to achieving the government debt ceilings mandated by the 2001 Public Debt Law - namely that total and external government debt be reduced to less than 80 and 60 percent of GDP, respectively, by $2006 .{ }^{4}$ Over the last two years, the reduction of the ratio of government debt to GDP fell substantially short of the authorities' original plan, mainly as a result of valuation adjustments associated with cross-country exchange rate movements, lower privatization receipts, and lower-than-expected nominal GDP growth. The authorities recognized the need to accelerate their debt-reduction efforts through a combination of further fiscal adjustment, accelerated privatization, and prepayment of high-interest external debt. A step in this direction was made through the prepayment of Par Brady Bonds, which is expected to lower borrowing requirements by more than JD 10 million a year. The authorities were encouraged to rebalance their debt profile, in favor of domestic debt, in line with their new fiscal funding strategy and in consultation with the Paris Club (MEFP, paragraph 21). The analysis of the medium term fiscal strategy in the accompanying selected issues paper concludes that, notwithstanding the setbacks recorded in 2002 and 2003 mainly on account of exchange related valuations losses, public debt remain sustainable as it is projected to converge gradually to about 60 percent of GDP by 2010. Such a sustainable debt dynamics is resilient to significant domestic and external shocks, except for large exchange rate movements, which could significantly prolong the debt-reduction period, as witnessed in the last two years.

\section{Fiscal adjustment is further complicated by rigidities in government spending.}

About 70 percent of central government spending is nondiscretionary, partly associated with priority sectors. Specifically, spending on education and health - at 5 percent and 4.2 percent of GDP, respectively in 2002 - are among the highest in the region and would benefit from an improvement in the quality of spending rather than from an increase in outlays. Military and security-related outlays account for another $8 \frac{1}{2}$ percent of GDP or 22 percent of total spending, one of the highest levels by international and regional standards. The new government is keen to rationalize and reduce government spending, but acknowledged that this would take time and entail a difficult political consensus building process.

\footnotetext{
${ }^{4}$ Chapter V of the selected issues paper provides full details of the authorities' medium-term fiscal strategy.
} 


\section{B. Tax Policy and Tax Administration Reforms}

\section{The achievement of the revised fiscal strategy depends crucially on further tax}

efforts. On the one hand, the authorities have successfully implemented a comprehensive general sales tax system since 1994, which now raises $81 / 2$ percent of GDP and has, over time, offset the loss in trade-related taxes resulting from trade liberalization. On the other hand, the income tax system remains mired in a complicated structure with widespread exemptions. This has resulted in only a marginal increase in income tax collection in the last five years. Despite strong political opposition, the authorities agreed to consider some reforms in this area in the near future along the lines of Fund technical assistance recommendations.

18. Improvements in tax administration could also yield significant results. In early 2004, the ministry of finance integrated the Income Tax and Sales Tax Departments into a unified, function-based revenue department with procedures based on the principles of selfassessment and taxpayer segmentation (MEFP, paragraph 17). The new revenue department will eventually have large- and medium-taxpayer offices to increase its effectiveness. In addition, the use of single taxpayer identification numbers and the sharing of taxpayer information across the different tax departments will reduce the scope for tax evasion. The mission welcomed the authorities plan to move swiftly in establishing the new revenue department so as to reap some of the benefits of integration, beginning with the 2005 budget.

\section{Financial System Vulnerabilities}

\section{The Financial Sector Stability Assessment (FSSA) reports that the banking} system generally shows high capital ratios, liquidity, and profitability. However, nonperforming loans are high, and there are four undercapitalized banks, after the restructuring of one bank in January 2004, which account for 14 percent of banking system assets (Box 1). One of these banks - accounting for 2 percent of banking assets - is under temporary CBJ administration and is expected to be restructured in 2004, after criminal proceedings have been completed. The restructuring of the bank may require use of public funds in the range of JD 20-60 million (0.3-0.8 percent of GDP), depending on the extent of the assets recovered during the criminal proceedings. The mission noted that the agreement in January 2004 to restructure the bank under temporary CBJ administration could create a moral hazard for future bank resolutions, because it returns the bank to its original shareholders with a significant injection of public funds. The authorities were of the view that there was no moral hazard because the restructuring involved a substantial loss of the paid-in capital and injection of new capital by the original shareholders, the establishment of a new management and board of the bank, and a modest use of public funds that is likely to be recouped once the bank is fully viable again. They also pointed to the new prompt corrective action framework adopted in January 2004 as a safeguard against any further use of public funds. The authorities are working to restructure the four undercapitalized banks on the basis of time-bound action plans. 
20. The FSSA also emphasizes that monetary policy implementation has resulted in excess liquidity in the banking system and in a convergence of the interbank with the CBJ overnight interest rate. The mission noted that the short-term yield curve has become flat and interest rates are kept artificially high by the CBJ overnight deposit window interest rate (Figure 10). In addition, commercial banks held about JD 2.8 billion
Figure 10: Jordan and US Yield Curves, End-2003 (In percent)

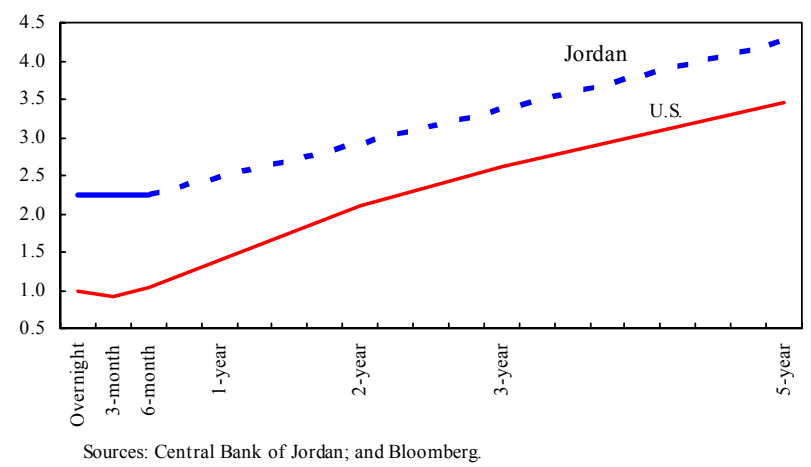

(40 percent of GDP) in CDs, excess

reserves, and overnight deposits at the $\mathrm{CBJ}$, which seems to have created incentives to fund projects through equity financing, as private sector credit expansion remains low. The authorities noted that the banks' remained cautious in their lending approach, in view of the difficult regional situation and the need to correct for bad credit decisions in the past. Jordan's regulatory and supervisory framework generally observes international standards and codes in banking, payments systems, securities, and insurance, reflecting the efforts to strengthen supervision during recent years.

\section{Sustainability of Recent Gains in the Export Sector}

\section{The export sector has been the main engine of growth for the Jordanian} economy over the last few years and is likely to remain so over the medium term. Both the authorities and the business community pointed to the growing interest of investors in Jordan as a gateway for duty- and quota-free exports to the EU and the United States, and, more recently, as a hub for reconstruction and investment activities in Iraq. Despite recent gains, the mission shared the authorities' views that Jordan is far from realizing its export potentials opened up by the QIZ initiative and FTA with the United States. So far, Jordanian exporters have not recorded gains from the more liberal access to the EU market under the Association Agreement, but with the recent depreciation of the dinar against the euro in real effective terms, Jordan should be in a better position in the coming years. The authorities underscored that tourism activity had reached a trough because of the war in Iraq and the ongoing conflict in West Bank and Gaza, and there was only upside potential over the medium-term, although the precise timing of the turnaround is still uncertain. They also pointed to the growing role of Jordan as a training center for the regional computer industry and for medical practices and tourism. They acknowledged, though, that domestic capacity constraints (including at the Aqaba port), higher domestic transportation costs, and a lack of skilled manpower could hinder the full growth potential in the external sector. In this regard, the mission welcomed the government's recent decision to privatize the Aqaba port management operations and to increase its handling capacity in 2004. 


\section{Box 1. Findings of Financial System Stability Assessment (FSSA)}

\section{Macroeconomic conditions have been conducive to financial stability, with external} developments potentially posing the greatest potential risk to financial stability. Jordan's financial system is dominated by the banking sector, which has provided a high level of intermediation. Most banks are well capitalized, liquid, profitable, and can withstand considerable shocks, but nonperforming loans are generally high, and there is high concentration in bank deposits and loans. There are four undercapitalized banks, after the recapitalization of one bank in January 2004, with about 14 percent of banking assets. Problems in these banks were the result of a major fraud case, weak corporate governance, and weaknesses in banking supervision, including the absence of a framework for prompt corrective measures. The CBJ is working toward the restructuring of these banks and has introduced a framework for prompt corrective measures. Banking supervision has been strengthened, and most prudential standards are in line with international best practice. The FSAP recommended that the CBJ monitor closely the problem banks, agree with them on time-bound restructuring plans, and be ready with measures in the event of deviations from the agreed restructuring plans. The FSAP also highlighted that the Jordanian banking system is vulnerable to geopolitical shocks.

\section{The FSAP also recommended the introduction of a margin between the interbank and CBJ} overnight deposit window rates. The interbank market has been repressed by excess liquidity and the administration of the overnight deposit window, which has led to a convergence of the CBJ overnight deposit window and certificate of deposit rates. Public debt and monetary management could benefit from closer monetary-fiscal coordination. The securities market is going through an impressive regulatory and technological improvement. Stock market capitalization is relatively high by international standards, but the turnover ratio is comparable to those of illiquid markets; the bond market is small. The securities market would benefit from privatization and from further financial deepening, including a longer yield curve. Insurance penetration is low despite a large number of companies. Its regulatory framework has been modernized recently. However, high initial capital requirements, and the grandfathering of existing companies may discourage entry and market innovation. Other priorities are to increase the independence of the Insurance Commission from government, and to ensure that companies maintain adequate reserves.

The public pension funds are being reformed to cope with growing pension liabilities. The government has taken measures to reduce expenditures in the military and civil service pension plans. Although the SSC has a large operating surplus at present and has built up assets worth 24 percent of GDP, its long-term financial position is being reassessed on the basis of an actuarial review. The recommendations of the review are expected to be implemented in 2004.

\section{Small- and medium-sized enterprises (SME) have benefited from government and donor} schemes that channel funds at subsidized terms, but this strategy tends to inhibit the development of sustainable intermediation in this market. SME credit facilities would benefit from wider access to reliable credit information, reducing transaction costs in realizing collateral, and phasing out subsidized lending. The payment system is modern and functioning relatively well. The expected approval of the draft anti-money laundering law will strengthen the currently fragmented framework and bring it in full compliance with international standards. 
22. The mission pointed to the downside risks that the elimination of textile and apparel quotas in 2005 under the WTO ATC may induce foreign investors to relocate to countries with cheaper labor costs. Based on scenarios prepared by the staff, the impact on the balance of payments of the ATC could be in the range of $\$ 85-\$ 340$ million per year (0.6-2.4 percent of 2008 GDP), depending on how much of the recent export growth in textiles and apparel will be affected by the ATC. The authorities considered these scenarios rather pessimistic and pointed to the establishment of 12 new foreign textile companies in the QIZs in 2003 and continued strong interest of foreign investors in relocating to Jordan, as indications that foreign investors still regard the duty exemption of QIZ exports as a sufficient advantage to relocate their business to Jordan.

\section{E. Exchange Rate Policy}

\section{The mission reviewed with the authorities the appropriateness of current} exchange rate policy. The authorities noted that the current peg to the dollar had helped Jordan bring down inflation to industrial country levels and that competitiveness was adequate, as evidenced by the robust export performance in recent years and the mediumterm outlook for exports. They noted that the fixed exchange rate regime has served Jordan well, including in view of recent Fund staff research documenting the prominence of nominal shocks faced by Jordan in recent years. They also observed that the current peg to the U.S. dollar was a natural nominal anchor, given that much of Jordan's external current account inflows were denominated in U.S. dollars or in currencies linked to the U.S. dollar.

\section{Policy Discussions Related to the Program for 2004}

\section{Understandings were reached on the macroeconomic framework for 2004}

(MEFP, paragraph 14). Real GDP growth is expected to reach 5 percent, supported by a strong export performance and a strengthening of domestic demand. Inflation would continue to be moderate. After allowing for a strong growth in non-oil imports, a modest rebound in tourism activity, and a significant reduction in external grants, the external current account surplus is expected to narrow to 5.3 percent of GDP. Gross usable reserves of the CBJ are expected to remain broadly unchanged at $\$ 4.7$ billion, equivalent to 9 months of prospective import cover and 42 percent of JD broad money.

25. The objective of the fiscal program for 2004 is to make sizable progress in the reduction in public debt, consistent with the medium term fiscal strategy (MEFP, paragraph 15). The authorities recognize that, although the targets under the Public Debt Law of 80 percent of GDP by 2006 could still be attainable, this will require stronger fiscal consolidation efforts. The 2004 budget, approved by parliament in February 2004, therefore limits the overall budget deficit to 3.9 percent of GDP, which fully preserves the overperformance recorded in 2003. The government expects to finance the additional payments postponed from 2003 through higher grants beyond the budgeted level that are under active consideration, but not yet fully secured. To ensure that the average deficit for 2003-04 would be less than the authorities' original fiscal strategy, the program provides that 
the 2004 deficit target may be increased to no more than 4.9 percent of GDP, in the event that these additional grants do not materialize.

26. The authorities will need to implement a sizable package of fiscal measures to achieve the fiscal deficit target of 2004 (MEFP, paragraph 15). The attainment of the fiscal deficit target (3.9 percent of GDP) is made more difficult by the loss of the Iraqi oil grant; the expected decline in external grants, following the generous financial support of the international community in 2003; and a significant upward revision in the World Economic Outlook (WEO) petroleum price projection. Tax revenue is budgeted to increase by about 0.3 percent of GDP in 2004, compared to 2003 outturn. The expected revenue increase is supported by a package of revenue measures (yielding 1.6 percent of GDP on an annualized basis) and administrative reform. Grants are projected to decline by $3 \frac{1}{2}$ percent of GDP, after the exceptional level of international support received in 2003, but would remain still high at 8.7 percent of GDP.

\section{The government revenue efforts will also be supplemented by spending cuts} (MEFP, paragraph 16) equivalent to 3 percent of GDP, thus reversing the fiscal stimulus of 2003. Current expenditure is programmed to decline by 3 percent of GDP compared to 2003, including about 1.1 percent of GDP in cuts envisaged in the budget, that will reduce military spending, purchases of goods and services, and transfers. Capital spending related to PSET execution is budgeted to be about 2.1 percent of GDP, in line with the projected availability of PSET grants. The implementation of the budget and the full utilization of privatization proceeds for debt reduction purposes should enable the authorities to reduce net government and government-guaranteed debt by $81 / 2$ percentage points of GDP to 93 percent of GDP by end-2004, based on current exchange rate assumptions.

\section{Monetary policy will continue to support the fixed exchange rate peg (MEFP,} paragraph 18). Broad money is expected to grow at $8 \frac{1}{2}$ percent, in line with nominal GDP growth. With a moderate increase in net foreign assets of the banking system, the projected growth in broad money would allow for a significant rebound in credit to the private sector. The authorities agreed with the staff's assessment in November 2003 that the still fragile recovery from the war in Iraq, weak credit demand, and the strength of the balance of payments called for further monetary easing. As a result, the CBJ reduced its overnight deposit rate by 25 basis points to 2 percent in December 2003. The mission shared the authorities' views that the large increase in reserve money in 2003 reflected a permanent shift in the real demand for money and that the authorities' partial sterilization was therefore appropriate.

\section{A. Structural Policies}

\section{The privatization program will be broadened and accelerated to promote} economic growth and help reduce the debt burden (MEFP, paragraph 22). The government plans to privatize a majority of the electricity generation and distribution companies in 2004. A portion of the government's shares in the Jordan Phosphate and the 
Jordan Telecommunications companies will be sold, as well as the remaining noncore activities of Royal Jordanian Airlines. The government also intends to privatize, or put under private management, the postal service and the Aqaba port. Overall, the privatization program is expected to raise JD 300 million in 2004.

\section{The pension reform has been completed (MEFP, paragraphs 9 and 23, and}

Box 2). As planned, new military recruits have been shifted to the Social Security Corporation (SSC) starting in June 2003, so as to reduce the burden on the budget over the long run. In January 2004, parliament approved the tightening of military disability pensions. The elimination of the so-called "four-year rule," which provides military officers with a pension of the next higher rank if they have served four or more years in their rank, was approved by parliament in March 2004. The government is reviewing the draft actuarial review of the SSC and, once the report is finalized in mid-2004, it plans to implement the recommendations. The government is also committed to the gradual elimination of the remaining price subsidies on petroleum products and the eventual liberalization of the sector, once the exclusive concession for the oil refinery expires in 2008 (MEFP, paragraph 25).

31. Further progress has been achieved in the area of trade liberalization. In February 2004, Jordan, Egypt, Morocco and Tunisia formally reached an agreement towards the creation of a Euro-Mediterranean free trade area by 2010 . The authorities also concluded negotiations with Singapore towards the creation of a free trade area and greater cooperation for investment in high value added industries. While welcoming these developments, the mission underscored the importance of further reductions in import tariff and non-tariff barriers, including beyond Jordan's current commitments under the WTO to lower the maximum tariff from 30 to 20 percent by 2010 .

\section{The safeguards assessment of the CBJ, which was completed on June 27, 2003,} concluded that there are currently no significant systemic vulnerabilities and that the CBJ has made commendable progress in strengthening its safeguards, along the lines recommended in the previous safeguards assessment of May 2001. However, the assessment noted that there are still some unresolved issues at various levels of the bank's operations, including the need for greater transparency in the CBJ's financial statements, and some minor anomalies with data reporting. Consequently, the assessment proposed a series of measures to address the identified weaknesses and, in response, the authorities have established internal procedures for the CBJ's internal audit to conduct monthly reviews of the monetary data used for program purposes and have amended the contract for the external audit of the CBJ's financial accounts in compliance with the safeguards assessment recommendations (a structural benchmark at end-2003 under the program). 


\section{Box 2. Jordan-Structural Conditionality}

The current SBA continues to support the authorities' structural reform agenda in order to improve Jordan's long-term growth prospects.

Coverage of structural conditionality in the 2004 program - The program envisages two structural benchmarks: (i) the publication of balance of payments statistics by May 2004, in line with the recommendations of the data ROSC, and (ii) the integration, by March 2004, of the Income and Sales Tax Departments in a function-based revenue department and the establishment of a temporary directorate to oversee the large- and medium-taxpayers offices.

Status of earlier (2002-03) structural conditionality - Two structural performance criteria on the enrolment of new military recruits in the SSC and the tightening of eligibility criteria for military pensions have now been completed, albeit with a delay. The five structural benchmarks on: (i) the development of a risk-based audit plan to audit GST taxpayers; (ii) the reduction of the ratio of GST nonfilers to 10 percent of the total taxpayers; (iii) the implementation of a single treasury account at the CBJ; (iv) the engagement of an externally recognized audit firm for the auditing of the $2003 \mathrm{CBJ}$ financial statements, with the provision of a review by an international partner; and (v) the implementation of prompt corrective actions stipulating automatic penalties for violations of prudential regulations by banks, have been completed.

Structural areas covered by World Bank lending and conditionality—The World Bank has supported Jordan's economic reform and development efforts through a Public Sector Reform Loan of $\$ 120$ million approved in July 2002. The reforms address the quality and accessibility of public services to households and businesses, and include ongoing reforms of the judicial system and the civil service.

Other relevant structural measures not included in the current program-The government is undertaking significant reforms in the power sector with assistance from the World Bank, but these reforms are no longer subject to Fund conditionality. The government is also actively working with bilateral donors in the reform of the water sector, improvements in health provision, alleviation of poverty, and employment creation through training programs.

\section{The authorities have made substantial progress toward subscribing to the Fund} Special Data Dissemination Standard (SDDS) in the last two years, according to the Update to the 2002 Report on the Observance of Standards and Codes (ROSC) - Data Module (Appendix III). The CBJ will shortly be in a position to publish revised balance of payments statistics and the international reserves template according to the latest Fund standards, supported by technical assistance from the Fund. A short-term fiscal expert will also visit Amman in March 2004 to help the ministry of finance publish general government statistics. 


\section{Staff Appraisal}

\section{Jordan has successfully weathered the disruptions caused by the war in Iraq} through domestic efforts and international financial support. Continued export growth in markets outside the region, some easing of the monetary policy, and the fiscal stimulus financed through external grants helped offset depressed domestic demand, leading to a shorter and less accentuated slowdown in real GDP growth and a much stronger external position. The authorities' commitment to fiscal consolidation efforts, sound macroeconomic management, and the support from the international community were reflected in a remarkable degree of financial stability and a strengthening of private sector confidence, well beyond earlier expectations. Nevertheless, the loss of tourism receipts and the export market in Iraq, and a sharp drop in private investment, led to a virtual stagnation in per capita real GDP and slowed down the pace of employment generation.

\section{Progress in fiscal consolidation and the timely implementation of strong fiscal} measures, despite the difficult political environment, helped achieve the program's overall fiscal deficit targets comfortably. The structural contents of the revenue package and the reforms to strengthen tax administration have laid the foundation for sustaining the pace of fiscal consolidation over the medium term. The authorities' decision to accelerate capital spending and compensate the economic sectors adversely affected by the war, financed solely through increased external grants, was appropriate in the period immediately after the war. However, the recovery in external demand called for a withdrawal of the stimulus. In this context, the staff was particularly impressed by the new government's determination to achieve the fiscal deficit target by substantially tightening the stance of fiscal policy in the last two months of 2003 and offset the expenditure overruns experienced through October with cuts in other areas.

\section{The authorities' program for $\mathbf{2 0 0 4}$ is appropriate, reflecting the expected} recovery from the effect of the war in Iraq and the need to sustain fiscal consolidation and structural reforms. The 2004 budget approved by parliament is consistent with the medium-term fiscal strategy and contains another strong package of fiscal measures in support of the deficit target. The staff, in particular, welcomes the decisions/commitments to: (i) increase petroleum product prices, with a view to phase out remaining subsidies and recoup the loss of Iraqi oil grants over the next 2-3 years; (ii) implement other revenue measures entailing a broadening of the tax base and higher tax rates to achieve the fiscal deficit target; and (iii) finance all programs under the 2004 PSET through external grants and to use privatization proceeds entirely for debt-reduction purposes. To ensure the achievement of the fiscal deficit target, the staff urges the authorities to implement expeditiously the revenue measures and expenditure cuts underpinning the budget. The shortfalls in debt reduction in recent years, although for reasons beyond the control of the authorities, have eroded the cushion and exacerbated the risks for missing the targeted debt reduction, envisaged under the Public Debt Law. A stronger fiscal adjustment effort is therefore needed to offset the lost ground in debt reduction in recent years. Given the improved environment, the pace of the privatization program should also be accelerated, and the composition of 
public debt should be changed in favor of domestic debt through debt operations along the lines of the authorities' fiscal funding and debt-management strategy. Continued heavy reliance on external grants, and the consequent increase in the fiscal deficit, excluding grants, also poses a risk to the medium-term fiscal adjustment and debt-reduction paths.

\section{Based on the recent FSSA, Jordan's macroeconomic conditions have been} conducive for financial stability and the banking system is generally sound in terms of capital adequacy ratios, liquidity, and profitability. The problems with one small bank under temporary $\mathrm{CBJ}$ administration and three other undercapitalized banks under restructuring plans with the $\mathrm{CBJ}$ are, however, sources of discomfort. The staff urges the authorities to deal with these problem banks promptly under time-bound restructuring plans and to act decisively in the event of deviations from these plans. The authorities should also avoid the perception of moral hazard associated with the recent bank restructuring by forcefully implementing the recently adopted prompt corrective action framework and fully reflecting the associated loan write off in the balance sheet of the CBJ in accordance with international accounting standards. The convergence of the CBJ overnight deposit window rate and other short-term (three- and six-month) interest rates, the very high level of shortterm deposits with the CBJ, and the low rate of credit expansion to the private sector point to scope for further deepening of financial intermediation. In this regard, the staff welcomes the recent cut in the overnight window rate. In the event the recent increase in the real demand for money were to be reversed, the authorities should stand ready to use their liquidity management tools to protect the net international reserve target.

\section{The current peg to the U.S. dollar has brought notable benefits to Jordan,} including price stability, a high level of confidence in the dinar, a transparent anchor for monetary policy, and an added element of stability for investors and exporters. The empirical evidence on the valuation of the dinar, indicators of competitiveness, and international experience do not suggest an obvious need for changing Jordan's exchange rate system.

\section{The program has certain downside risks. Continued regional instability could} reduce the prospects for economic growth and accentuate poverty and unemployment in 2004 and over the medium term. Enforcing the substantial expenditure cuts envisaged under the 2004 budget — following an expenditure-induced fiscal stimulus in 2003 — will be a challenging task. Slower growth, a delay in the privatization program, and a further depreciation of the U.S. dollar, to which the Jordanian dinar is pegged, against other major currencies could also delay the achievement of debt sustainability by several years.

\section{Notwithstanding these risks, the staff recommends approval by the Executive} Board of the authorities' request for completion of the second review under the SBA, in view of the solid track record on performance and policy implementation under the program and the authorities' continued commitment to prudent financial policies. The staff also recommends approval of the request for a waiver of applicability of the March 31, 2004 performance criteria as the information needed to assess non-observance is unavailable and, notwithstanding such unavailability, staff believes the program will be successfully 
implemented and there is no clear evidence that the performance criteria will not be met. Jordan is on track to exit from Fund financial support after the completion of the current SBA, and the authorities' intention to treat the remainder of the program as precautionary is consistent with such an exit strategy. Jordan would continue with enhanced surveillance under the Post-Program Monitoring, which is presumed to remain in effect through end-2005 when Jordan's level of outstanding Fund resources would fall below 100 percent of its quota. The timeliness, coverage, and quality of data are adequate and the authorities' intention to subscribe to the SDDS is commendable. The next Article IV consultation will be held in accordance with the decision on consultation cycles for program countries. 
Table 1. Jordan: Summary of the Macroeconomic Framework, 2000-09

\begin{tabular}{|c|c|c|c|c|c|c|c|c|c|c|c|c|}
\hline & 2000 & 2001 & 2002 & $\begin{array}{l}\text { Prog. } \\
2003\end{array}$ & $\begin{array}{r}\text { Prel. Est. } \\
2003\end{array}$ & $\begin{array}{l}\text { Prog. } \\
2004\end{array}$ & $\begin{array}{l}\text { Proj. } \\
2004\end{array}$ & $\begin{array}{l}\text { Proj. } \\
2005\end{array}$ & $\begin{array}{l}\text { Proj. } \\
2006\end{array}$ & $\begin{array}{l}\text { Proj. } \\
2007\end{array}$ & $\begin{array}{l}\text { Proj. } \\
2008\end{array}$ & $\begin{array}{l}\text { Proj. } \\
2009\end{array}$ \\
\hline & \multicolumn{12}{|c|}{ (Annual percentage changes) } \\
\hline \multicolumn{13}{|l|}{ Output and prices } \\
\hline Real GDP at market prices & 4.1 & 4.2 & 5.0 & 3.0 & 3.2 & 5.5 & 5.0 & 5.5 & 6.0 & 6.0 & 6.0 & 6.0 \\
\hline GDP deflator at market prices & -0.2 & 0.0 & 0.4 & 1.5 & 1.9 & 1.8 & 2.5 & 1.8 & 1.8 & 1.8 & 1.8 & 1.8 \\
\hline Nominal GDP at market prices & 3.8 & 5.4 & 5.4 & 4.6 & 5.1 & 7.4 & 7.6 & 7.4 & 7.9 & 7.9 & 7.9 & 7.9 \\
\hline Consumer price index (annual average) & 0.7 & 1.8 & 1.8 & 2.5 & 2.3 & 1.8 & 3.0 & 1.8 & 1.8 & 1.8 & 1.8 & 1.8 \\
\hline Consumer price index (end of period) & -1.9 & 3.8 & 0.5 & 1.8 & 3.6 & 1.8 & 1.8 & 1.8 & 1.8 & 1.8 & 1.8 & 1.8 \\
\hline \multirow[t]{2}{*}{ Nominal GDP at market prices (in millions of JD) } & 5,989 & 6,310 & 6,653 & 6,896 & 6,991 & 7,407 & 7,524 & 8,080 & 8,719 & 9,409 & 10,153 & 10,956 \\
\hline & \multicolumn{12}{|c|}{ (In percent of GDP) } \\
\hline \multicolumn{13}{|l|}{ Inverstment and savings } \\
\hline Gross domestic investment & 22.2 & 22.2 & 22.5 & 22.8 & 22.3 & 25.1 & 23.5 & 25.1 & 26.9 & 27.3 & 27.3 & 26.2 \\
\hline Government & 5.2 & 5.8 & 6.7 & 6.9 & 8.8 & 7.2 & 7.7 & 7.0 & 6.9 & 6.8 & 6.7 & 5.5 \\
\hline Other & 16.9 & 16.4 & 15.8 & 15.9 & 13.5 & 17.9 & 15.8 & 18.1 & 20.0 & 20.5 & 20.6 & 20.7 \\
\hline Gross national savings & 22.9 & 22.2 & 27.0 & 27.4 & 33.3 & 25.8 & 28.8 & 26.7 & 27.0 & 27.3 & 27.2 & 26.0 \\
\hline Government & 0.5 & 2.2 & 1.7 & 4.4 & 7.7 & 3.3 & 3.8 & 3.7 & 4.1 & 4.3 & 4.2 & 3.0 \\
\hline Other & 22.4 & 20.0 & 25.3 & 23.0 & 25.6 & 22.5 & 25.0 & 23.0 & 22.9 & 23.0 & 23.0 & 23.0 \\
\hline Savings-investment balance & 0.7 & 0.0 & 4.5 & 4.6 & 11.1 & 0.7 & 5.3 & 1.6 & 0.2 & 0.0 & -0.1 & -0.2 \\
\hline Government & -4.7 & -3.7 & -5.0 & -2.5 & -1.1 & -3.9 & -3.9 & -3.3 & -2.8 & -2.5 & -2.5 & -2.5 \\
\hline Other & 5.4 & 3.6 & 9.4 & 7.1 & 12.1 & 4.6 & 9.2 & 4.9 & 3.0 & 2.5 & 2.4 & 2.3 \\
\hline \multicolumn{13}{|l|}{ Fiscal operations } \\
\hline Revenue and grants & 30.1 & 30.5 & 30.2 & 35.2 & 35.9 & 31.0 & 32.3 & 28.7 & 27.2 & 26.5 & 26.6 & 26.2 \\
\hline Of which: grants & 4.2 & 4.3 & 5.2 & 10.8 & 12.1 & 5.7 & 8.7 & 4.6 & 3.0 & 2.2 & 2.1 & 1.7 \\
\hline Expenditure and net lending (incl. off-budget accounts) & 34.8 & 34.2 & 35.2 & 37.7 & 37.0 & 34.9 & 36.2 & 32.0 & 30.0 & 29.0 & 29.1 & 28.7 \\
\hline Overall fiscal balance (after grants) & -4.7 & -3.7 & -5.0 & -2.5 & -1.1 & -3.9 & -3.9 & -3.3 & -2.8 & -2.5 & -2.5 & -2.5 \\
\hline \multicolumn{13}{|l|}{ Government and } \\
\hline government guaranteed debt $1 /$ & 100.0 & 97.0 & 100.5 & 96.5 & 101.5 & 88.6 & 93.0 & 86.7 & 80.0 & 75.1 & 69.2 & 63.3 \\
\hline Of which: external & 84.2 & 78.7 & 80.4 & 76.6 & 77.1 & 70.9 & 68.2 & 62.4 & 56.4 & 51.3 & 46.9 & 42.1 \\
\hline \multicolumn{13}{|l|}{ External sector } \\
\hline \multirow[t]{2}{*}{ Current account balance (after grants) } & 0.7 & 0.0 & 4.5 & 4.6 & 11.1 & 0.7 & 5.3 & 1.6 & 0.2 & 0.0 & -0.1 & -0.2 \\
\hline & \multicolumn{12}{|c|}{ (Annual percentage changes in U.S. dollar terms) } \\
\hline Merchandise exports & 3.7 & 20.8 & 20.8 & 1.0 & 8.2 & 6.2 & 8.3 & 5.8 & 6.7 & 6.0 & 7.0 & 7.0 \\
\hline \multirow[t]{2}{*}{ Merchandise imports } & 23.7 & 5.6 & 3.5 & 7.8 & 10.8 & 6.0 & 9.7 & 6.7 & 6.9 & 5.1 & 7.1 & 7.4 \\
\hline & \multicolumn{12}{|c|}{ (Changes in percent of beginning of period broad money) } \\
\hline \multicolumn{13}{|l|}{ Monetary sector } \\
\hline Net foreign assets & 12.6 & 1.8 & 5.4 & 5.3 & 11.4 & 2.6 & 2.1 & 1.5 & 1.4 & 1.2 & 1.8 & 1.4 \\
\hline Broad money & 10.2 & 5.8 & 7.0 & 7.1 & 11.0 & 8.4 & 8.5 & 8.4 & 8.9 & 8.9 & 8.9 & 8.9 \\
\hline \multicolumn{13}{|l|}{ Memorandum items: } \\
\hline Nominal per capita GDP (in U.S. dollars) & 1,675 & 1,717 & 1,761 & 1,776 & 1,800 & 1,855 & 1,885 & 1,969 & 2,067 & 2,169 & 2,277 & 2,390 \\
\hline $\begin{array}{l}\text { Gross usable international reserves } \\
\text { (in U.S. dollar millions) } 2 / 3 /\end{array}$ & 2,742 & 2,565 & 3,474 & 3,913 & 4,745 & 3,950 & 4,700 & 4,664 & 4,563 & 4,443 & 4,435 & 4,408 \\
\hline In months of prospective imports of GNFS 4/ & 6.4 & 6.0 & 7.8 & 8.0 & 9.7 & 7.6 & 9.0 & 8.3 & 7.7 & 6.9 & 6.4 & 6.2 \\
\hline As percent of JD broad money & 33.2 & 30.1 & 38.1 & 40.1 & 46.5 & 37.2 & 42.2 & 38.5 & 34.5 & 30.7 & 28.0 & 25.5 \\
\hline Net International Reserves (in millions of U.S. dollars) 2/ & 2,275 & 2,111 & 3,032 & 3,464 & 4,436 & 3,590 & 4,479 & 4,479 & 4,438 & 4,379 & 4,421 & 4,394 \\
\hline U.S. dollar per Jordanian dinar (period average) & 1.41 & 1.41 & 1.41 & $\ldots$ & 1.41 & $\ldots$ & $\ldots$ & $\ldots$ & $\ldots$ & $\ldots$ & $\ldots$ & $\ldots$ \\
\hline Real effective exchange rate (end of period) & 123.0 & 131.1 & 121.5 & $\ldots$ & 111.5 & $\ldots$ & $\ldots$ & $\ldots$ & $\ldots$ & $\ldots$ & $\ldots$ & $\ldots$ \\
\hline Percent change (+: appreciation) & 2.9 & 6.6 & -7.3 & $\ldots$ & -8.3 & $\ldots$ & $\ldots$ & $\ldots$ & $\ldots$ & $\ldots$ & $\ldots$ & $\ldots$ \\
\hline
\end{tabular}

Sources: Jordanian authorities; and Fund staff estimates and projections.

1/ Domestic debt is net of government deposits with the banking system, and external debt includes collateralized Brady bonds.

2/ Net of short-term foreign liabilities and excluding commercial banks' foreign currency deposits with the Central Bank of Jordan.

3/ Excludes pledged assets under the 1993 commercial debt rescheduling agreement and the yearly change in foreign currency swaps.

4/ Imports of goods and nonfactor services, excluding imports for re-export, in subsequent 12 months. 
Table 2. Jordan: Summary Fiscal Operations, 2000-07

\begin{tabular}{|c|c|c|c|c|c|c|c|c|c|}
\hline & 2001 & 2002 & $\begin{array}{r}\text { Prog. } \\
2003 \\
\end{array}$ & $\begin{array}{c}\text { Prel. } \\
\text { Est. } \\
2003\end{array}$ & $\begin{array}{r}\text { Prog. } \\
2004 \\
\end{array}$ & $\begin{array}{l}\text { Rev. } \\
\text { Proj. } \\
2004 \\
\end{array}$ & $\begin{array}{l}\text { Proj. } \\
2005\end{array}$ & $\begin{array}{l}\text { Proj. } \\
2006\end{array}$ & $\begin{array}{l}\text { Proj. } \\
2007 \\
\end{array}$ \\
\hline & \multicolumn{9}{|c|}{ (In millions of Jordanian dinars) } \\
\hline Total budgetary revenue and grants & 1,926 & 2,010 & 2,426 & 2,511 & 2,294 & 2,431 & 2,322 & 2,368 & 2,494 \\
\hline Budgetary revenue & 1,653 & 1,667 & 1,684 & 1,665 & 1,869 & 1,779 & 1,953 & 2,109 & 2,285 \\
\hline Tax revenue & 1,020 & 1,000 & 1,053 & 1,083 & 1,129 & 1,186 & 1,268 & 1,364 & 1,460 \\
\hline Of which: Taxes on income and profits & 195 & 196 & 196 & 195 & 221 & 212 & 228 & 245 & 265 \\
\hline General sales tax & 515 & 511 & 577 & 596 & 625 & 700 & 760 & 822 & 880 \\
\hline Taxes on foreign trade & 240 & 220 & 196 & 209 & 200 & 190 & 190 & 199 & 211 \\
\hline Nontax revenue & 633 & 667 & 631 & 582 & 740 & 593 & 685 & 745 & 824 \\
\hline Of which: Fees & 215 & 225 & 241 & 249 & 259 & 242 & 259 & 280 & 302 \\
\hline Oil surplus & 98 & 110 & 67 & 23 & 117 & 33 & 95 & 122 & 152 \\
\hline Grants 1/ & 273 & 343 & 742 & 846 & 425 & 651 & 369 & 259 & 210 \\
\hline Total budgetary expenditure & 2,116 & 2,310 & 2,600 & 2,678 & 2,660 & 2,648 & 2,757 & 2,916 & 3,107 \\
\hline Current expenditure of which: & 1,791 & 1,852 & 2,111 & 2,057 & 2,117 & 2,046 & 2,179 & 2,302 & 2,454 \\
\hline Wages and salaries & 380 & 407 & 433 & 419 & 449 & 453 & 471 & 491 & 530 \\
\hline Interest payments & 279 & 252 & 280 & 270 & 283 & 253 & 290 & 298 & 306 \\
\hline Military expenditure & 537 & 551 & 597 & 629 & 641 & 623 & 679 & 732 & 790 \\
\hline Transfers & 453 & 505 & 647 & 582 & 583 & 547 & 575 & 607 & 641 \\
\hline $\begin{array}{l}\text { Purchases of goods and services } \\
\text { Puses }\end{array}$ & 82 & 81 & 101 & $\begin{array}{r}502 \\
94\end{array}$ & 104 & 95 & 94 & 97 & 105 \\
\hline Capital expenditure & 326 & 433 & 468 & 601 & 520 & 558 & 556 & 591 & 628 \\
\hline Of which: PSET spending & 0 & 58 & 107 & 179 & 120 & 159 & 120 & 120 & 120 \\
\hline Net lending & 0 & 25 & 21 & 20 & 22 & 44 & 21 & 23 & 25 \\
\hline Privatization account spending & 42 & 0 & 0 & 4 & 0 & 0 & 0 & 0 & 0 \\
\hline Non-budget accounts, net 2/ & -2 & 31 & 0 & -98 & 0 & 75 & 0 & 0 & 0 \\
\hline Measures to be identified 3/ & $\ldots$ & $\ldots$ & 0 & 0 & 77 & 0 & 169 & 135 & 74 \\
\hline Overall balance, including grants 1 / & -231 & -331 & -175 & -73 & -289 & -293 & -267 & -244 & -235 \\
\hline Financing & 231 & 331 & 175 & 73 & 289 & 293 & 267 & 244 & 235 \\
\hline Foreign financing (net) & 95 & 78 & 35 & -323 & 48 & -174 & -31 & -50 & -41 \\
\hline Privatization receipts (net) & -6 & 79 & 100 & 88 & 300 & 300 & 200 & 200 & 100 \\
\hline \multirow[t]{2}{*}{ Domestic financing (net) } & 143 & 175 & 39 & 309 & -59 & 167 & 98 & 95 & 177 \\
\hline & \multicolumn{9}{|c|}{ (In percent of period GDP) } \\
\hline Total budgetary revenue and grants & 30.5 & 30.2 & 35.2 & 35.9 & 31.0 & 32.3 & 28.7 & 27.2 & 26.5 \\
\hline $\begin{array}{l}\text { Budgetary revenue } \\
\text { Butus }\end{array}$ & 26.2 & 25.1 & 24.4 & 23.8 & 25.2 & 23.6 & 24.2 & 24.2 & 24.3 \\
\hline Tax revenue & 16.2 & 15.0 & 15.3 & 15.5 & 15.2 & 15.8 & 15.7 & 15.6 & 15.5 \\
\hline Of which: Taxes on income and profits & 3.1 & 2.9 & 2.8 & 2.8 & 3.0 & 2.8 & 2.8 & 2.8 & 2.8 \\
\hline $\begin{array}{l}\text { General sales tax } \\
\text { Gello }\end{array}$ & 8.2 & 7.7 & 8.4 & 8.5 & 8.4 & $\begin{array}{l}2.0 \\
9.3\end{array}$ & 9.4 & 9.4 & 9.4 \\
\hline Taxes on foreign trade & 3.8 & 3.3 & 2.8 & 3.0 & 2.7 & 2.5 & 2.4 & 2.3 & 2.2 \\
\hline Nontax revenue & 10.0 & 10.0 & 9.2 & 8.3 & 10.0 & 7.9 & 8.5 & 8.5 & 8.8 \\
\hline Of which: Fees & $\begin{array}{r}10.0 \\
3.4\end{array}$ & $\begin{aligned} 10.0 \\
3.4\end{aligned}$ & $\begin{array}{l}9.2 \\
3.5\end{array}$ & $\begin{array}{l}8.3 \\
3.6\end{array}$ & $\begin{array}{r}10.0 \\
3.5\end{array}$ & 3.2 & $\begin{array}{l}8.5 \\
3.2\end{array}$ & $\begin{array}{l}8.5 \\
3.2\end{array}$ & $\begin{array}{l}8.8 \\
3.2\end{array}$ \\
\hline Oil surplus & 1.6 & 1.7 & 1.0 & 0.3 & 1.6 & 0.4 & 1.2 & 1.4 & 1.6 \\
\hline Grants 1/ & 4.3 & 5.2 & 10.8 & 12.1 & 5.7 & 8.7 & 4.6 & 3.0 & 2.2 \\
\hline Total budgetary expenditure & 33.5 & 34.7 & 37.7 & 38.3 & 35.9 & 35.2 & 34.1 & 33.4 & 33.0 \\
\hline Current expenditure of which: & 28.4 & 27.8 & 30.6 & 29.4 & 28.6 & 27.2 & 27.0 & $\begin{array}{l}25.4 \\
26.4\end{array}$ & 26.1 \\
\hline $\begin{array}{l}\text { Wages and salaries } \\
\text {. }\end{array}$ & $\begin{array}{r}28.4 \\
6.0\end{array}$ & 6.1 & $\begin{array}{r}50.0 \\
6.3\end{array}$ & $\begin{array}{r}29.4 \\
6.0\end{array}$ & $\begin{array}{r}28.0 \\
6.1\end{array}$ & $\begin{array}{r}6.2 \\
6.0\end{array}$ & 5.8 & $\begin{array}{r}20.4 \\
5.6\end{array}$ & $\begin{array}{r}20.1 \\
5.6\end{array}$ \\
\hline Interest payments & 4.4 & 3.8 & 4.1 & 3.9 & 3.8 & 3.4 & 3.6 & 3.4 & 3.3 \\
\hline Military expenditure & 8.5 & $\begin{array}{l}3.0 \\
8.3\end{array}$ & $\begin{array}{l}4.1 \\
8.7\end{array}$ & 9.0 & $\begin{array}{l}5.0 \\
8.7\end{array}$ & $\begin{array}{l}3.4 \\
8.3\end{array}$ & $\begin{array}{l}3.0 \\
8.4\end{array}$ & $\begin{array}{l}5.4 \\
8.4\end{array}$ & 8.4 \\
\hline Transfers & 7.2 & 7.6 & 9.4 & 8.3 & 7.9 & 7.3 & 7.1 & 7.0 & 6.8 \\
\hline Purchases of goods and services & 1.3 & 1.2 & 1.5 & 1.3 & 1.4 & 1.3 & 1.2 & 1.1 & 1.1 \\
\hline Capital expenditure & $\begin{array}{l}1.3 \\
5.2\end{array}$ & $\begin{array}{l}1.2 \\
6.5\end{array}$ & 6.8 & $\begin{array}{l}1.3 \\
8.6\end{array}$ & $\begin{array}{l}1.4 \\
7.0\end{array}$ & $\begin{array}{l}1.3 \\
7.4\end{array}$ & $\begin{array}{l}1.2 \\
6.9\end{array}$ & $\begin{array}{l}1.1 \\
6.8\end{array}$ & $\begin{array}{l}1.1 \\
6.7\end{array}$ \\
\hline Of which: PSET spending & 0.0 & 0.9 & 1.5 & 2.6 & 1.6 & 2.1 & 1.5 & 1.4 & 1.3 \\
\hline Net lending & 0.0 & 0.4 & 0.3 & 0.3 & 0.3 & 0.6 & 0.3 & 0.3 & 0.3 \\
\hline Privatization account spending & 0.7 & 0.0 & 0.0 & 0.1 & 0.0 & 0.0 & 0.0 & 0.0 & 0.0 \\
\hline Nonbudget accounts, net 2/ & 0.0 & 0.5 & 0.0 & -1.4 & 0.0 & 1.0 & 0.0 & 0.0 & 0.0 \\
\hline Measures to be identified 3/ & $\ldots$ & $\ldots$ & 0.0 & 0.0 & 1.0 & 0.0 & 2.1 & 1.6 & 0.8 \\
\hline Overall balance, including grants 1 / & -3.7 & -5.0 & -2.5 & -1.1 & -3.9 & -3.9 & -3.3 & -2.8 & -2.5 \\
\hline Financing & 3.7 & 5.0 & 2.5 & 1.1 & 3.9 & 3.9 & 3.3 & 2.8 & 2.5 \\
\hline Foreign financing (net) & 1.5 & 1.2 & 0.5 & -4.6 & 0.6 & -2.3 & -0.4 & -0.6 & -0.4 \\
\hline Privatization receipts (net) & -0.1 & 1.2 & 1.5 & 1.3 & 4.1 & 4.0 & 2.5 & 2.3 & 1.1 \\
\hline Domestic financing (net) & 2.3 & 2.6 & 0.6 & 4.4 & -0.8 & 2.2 & 1.2 & 1.1 & 1.9 \\
\hline \multicolumn{10}{|l|}{ Memorandum items } \\
\hline Overall balance, excluding grants & -8.0 & -10.1 & -13.3 & -13.1 & -9.6 & -12.5 & -7.9 & -5.8 & -4.7 \\
\hline $\begin{array}{l}\text { Primary balance including grants } \\
\text { Pry }\end{array}$ & 0.8 & $\begin{array}{l}-10.1 \\
-1.2\end{array}$ & $\begin{array}{r}-1.5 \\
1.5\end{array}$ & $\begin{array}{r}-15.1 \\
2.8\end{array}$ & $\begin{array}{l}-9.0 \\
-0.1\end{array}$ & -0.5 & 0.3 & 0.6 & 0.8 \\
\hline Debt creating balance $4 /$ & -3.8 & -3.8 & -1.6 & -0.2 & -0.2 & -0.3 & -0.8 & -0.5 & -1.4 \\
\hline PSET spending & 0.0 & 0.9 & 1.5 & 2.6 & 1.6 & 2.1 & 1.5 & 1.4 & 1.3 \\
\hline Off-budget on-lending & 0.9 & 0.8 & 0.5 & 0.7 & 0.4 & 0.4 & 0.0 & 0.0 & 0.0 \\
\hline Government and government guaranteed debt 5 / & 97.0 & 100.5 & & 101.5 & $\ldots$ & 93.0 & 86.7 & 80.0 & 75.1 \\
\hline GDP at market prices (in JD million) & 6,310 & 6,653 & 6,896 & 6,991 & 7,407 & 7,524 & 8,080 & 8,719 & 9,409 \\
\hline
\end{tabular}

Sources: Jordanian authorities; and Fund staff estimates.

1/ The 2004 grant projections include JD 75 million in grants that have not yet been secured. In the event that the grants do not materialize, the fiscal deficit will be adjusted by up to JD 75 million.

2/ Includes discrepancy. In 2003 includes spending on building up the strategic oil reserve and payment commitments delayed due to the war in Iraq. In 2004, includes settlement of the payment commitments delayed in 2003.

3/ Additional measures needed to reach the fiscal deficit target. In the year $t$ it is assumed that the additional measures in the year $t-1$ were implemented. The 2004 proposed budget includes a commitment to cut expenditures by JD 80 million.

4/ Deficit net of privatization receipts and debt swaps. Includes off-budget on-lending.

5/ Domestic debt is net of government deposits with the banking system, and external debt includes collateralized Brady bonds. 
Table 3. Jordan: Summary Monetary Survey, 2001-04

\begin{tabular}{|c|c|c|c|c|c|c|c|c|c|c|c|}
\hline & & & & & & Prog. & Prel. Est. & Proj. & Proj. & Proj. & Proj. \\
\hline & 2001 & 2002 & 2003 & 2003 & 2003 & 2003 & 2003 & 2004 & 2004 & 2004 & 2004 \\
\hline & Dec. & Dec. & Mar. & June & Sept. & Dec. & Dec. & Mar. & Jun. & Sept. & Dec. \\
\hline & \multicolumn{11}{|c|}{ (Stocks in millions of Jordanian dinars) } \\
\hline Net foreign assets & 3,985 & 4,411 & 4,499 & 4,998 & 5,352 & 4,857 & 5,371 & 5,356 & 5,422 & 5,532 & 5,564 \\
\hline Net domestic assets & 3,881 & 4,008 & 4,129 & 3,916 & 3,935 & 4,095 & 3,974 & 4,191 & 4,315 & 4,545 & 4,578 \\
\hline Net claims on government & 1,310 & 1,412 & 1,465 & 1,265 & 1,331 & 1,259 & 1,346 & 1,477 & 1,261 & 1,336 & 1,479 \\
\hline of which: on central government 1/ & 1,330 & 1,403 & 1,412 & 1,212 & 1,286 & 1,255 & 1,398 & 1,529 & 1,313 & 1,387 & 1,531 \\
\hline Claims on nonfinancial public enterprises & 284 & 261 & 265 & 264 & 280 & 265 & 278 & 278 & 278 & 278 & 278 \\
\hline Claims on financial institutions & 79 & 75 & 75 & 75 & 74 & 75 & 73 & 73 & 73 & 73 & 73 \\
\hline Claims on the private sector & 4,696 & 4,848 & 4,930 & 4,940 & 4,966 & 5,268 & 5,016 & 5,202 & 5,542 & 5,698 & 5,587 \\
\hline Other items (net) & $-2,488$ & $-2,588$ & $-2,605$ & $-2,629$ & $-2,716$ & $-2,772$ & $-2,739$ & $-2,839$ & $-2,839$ & $-2,839$ & $-2,839$ \\
\hline Broad money & 7,866 & 8,419 & 8,628 & 8,914 & 9,287 & 8,952 & 9,345 & 9,547 & 9,736 & 10,078 & 10,142 \\
\hline Currency in circulation & 1,202 & 1,253 & 1,367 & 1,396 & 1,406 & 1,308 & 1,444 & 1,472 & 1,497 & 1,546 & 1,552 \\
\hline Jordanian dinar deposits & 4,842 & 5,218 & 5,221 & 5,474 & 5,770 & 5,564 & 5,797 & 5,936 & 6,064 & 6,288 & 6,336 \\
\hline \multirow[t]{2}{*}{ Foreign currency deposits } & 1,821 & 1,949 & 2,041 & 2,044 & 2,111 & 2,079 & 2,105 & 2,140 & 2,175 & 2,244 & 2,253 \\
\hline & \multicolumn{11}{|c|}{ (Cumulative flows in millions of Jordanian dinars) } \\
\hline Net foreign assets & 133 & 426 & 88 & 587 & 940 & 446 & 960 & -15 & 51 & 161 & 193 \\
\hline Net domestic assets & 298 & 127 & 121 & -92 & -73 & 87 & -34 & 217 & 341 & 571 & 604 \\
\hline Net claims on government & 207 & 102 & 53 & -147 & -81 & -153 & -66 & 131 & -85 & -11 & 132 \\
\hline of which: on central government 1 / & 178 & 73 & 9 & -191 & -117 & -148 & -5 & 131 & -85 & -11 & 132 \\
\hline Claims on nonfinancial public enterprises & -33 & -23 & 3 & 3 & 19 & 3 & 17 & 0 & 0 & 0 & 0 \\
\hline Claims on financial institutions & -1 & -4 & 0 & 1 & -1 & 0 & -1 & 0 & 0 & 0 & 0 \\
\hline Claims on the private sector & 484 & 152 & 82 & 92 & 119 & 421 & 168 & 186 & 526 & 682 & 571 \\
\hline Other items (net) & -359 & -100 & -18 & -41 & -128 & -184 & -151 & -100 & -100 & -100 & -100 \\
\hline Broad money & 431 & 553 & 209 & 495 & 868 & 533 & 926 & 202 & 391 & 733 & 797 \\
\hline Currency in circulation & -37 & 50 & 114 & 143 & 153 & 56 & 191 & 28 & 54 & 102 & 109 \\
\hline Jordanian dinar deposits & 231 & 376 & 3 & 256 & 552 & 347 & 579 & 139 & 267 & 491 & 539 \\
\hline \multirow[t]{2}{*}{ Foreign currency deposits } & 238 & 127 & 92 & 95 & 163 & 131 & 156 & 36 & 71 & 139 & 149 \\
\hline & \multicolumn{11}{|c|}{ (Cumulative flows in percent of beginning-of-period broad money) } \\
\hline Net foreign assets & 1.8 & 5.4 & 1.0 & 7.0 & 11.2 & 5.3 & 11.4 & -0.2 & 0.5 & 1.7 & 2.1 \\
\hline Net domestic assets & 4.0 & 1.6 & 1.4 & -1.1 & -0.9 & 1.0 & -0.4 & 2.3 & 3.6 & 6.1 & 6.5 \\
\hline Net claims on government & 2.8 & 1.3 & 0.6 & -1.7 & -1.0 & -1.8 & -0.8 & 1.4 & -0.9 & -0.1 & 1.4 \\
\hline of which: on general government 1 / & 2.4 & 0.9 & 0.1 & -2.3 & -1.4 & -1.8 & -0.1 & 1.4 & -0.9 & -0.1 & 1.4 \\
\hline Claims on nonfinancial public enterprises & -0.4 & -0.3 & 0.0 & 0.0 & 0.2 & 0.0 & 0.2 & 0.0 & 0.0 & 0.0 & 0.0 \\
\hline Claims on financial institutions & 0.0 & -0.1 & 0.0 & 0.0 & 0.0 & 0.0 & 0.0 & 0.0 & 0.0 & 0.0 & 0.0 \\
\hline Claims on the private sector & 6.5 & 1.9 & 1.0 & 1.1 & 1.4 & 5.0 & 2.0 & 2.0 & 5.6 & 7.3 & 6.1 \\
\hline Other items (net) & -4.8 & -1.3 & -0.2 & -0.5 & -1.5 & -2.2 & -1.8 & -1.1 & -1.1 & -1.1 & -1.1 \\
\hline Broad money & 5.8 & 7.0 & 2.5 & 5.9 & 10.3 & 6.3 & 11.0 & 2.2 & 4.2 & 7.8 & 8.5 \\
\hline Currency in circulation & -0.5 & 0.6 & 1.4 & 1.7 & 1.8 & 0.7 & 2.3 & 0.3 & 0.6 & 1.1 & 1.2 \\
\hline Jordanian dinar deposits & 3.1 & 4.8 & 0.0 & 3.0 & 6.6 & 4.1 & 6.9 & 1.5 & 2.9 & 5.3 & 5.8 \\
\hline Foreign currency deposits & 3.2 & 1.6 & 1.1 & 1.1 & 1.9 & 1.6 & 1.9 & 0.4 & 0.8 & 1.5 & 1.6 \\
\hline \multicolumn{12}{|l|}{ Memorandum items: } \\
\hline Annual growth in JD broad money (percent) & 3.3 & 7.0 & 6.7 & 7.7 & 9.6 & 6.2 & 11.9 & 12.4 & 10.1 & 9.2 & 8.9 \\
\hline Annual growth in broad money (percent) & 5.8 & 7.0 & 7.9 & 7.4 & 9.7 & 6.3 & 11.0 & 10.6 & 9.2 & 8.5 & 8.5 \\
\hline Annual growth in claims on the private sector (percent) & 11.5 & 3.2 & 4.6 & 3.6 & 3.3 & 8.7 & 3.5 & 5.5 & 12.2 & 14.7 & 11.4 \\
\hline Ratio of foreign currency to total deposits (percent) & 27.3 & 27.2 & 28.1 & 27.2 & 26.8 & 27.2 & 26.6 & 26.5 & 26.4 & 26.3 & 26.2 \\
\hline Currency/JD deposits (percent) & 24.8 & 24.0 & 26.2 & 25.5 & 24.4 & 23.5 & 24.9 & 24.8 & 24.7 & 24.6 & 24.5 \\
\hline
\end{tabular}

Sources: Central Bank of Jordan; and Fund staff projections and estimates.

1/ Excludes U.N. compensation funds and change in Brady bonds held by Jordanian banks. 
Table 4. Jordan: Summary Accounts of the Central Bank of Jordan, 2001-04

\begin{tabular}{|c|c|c|c|c|c|c|c|c|c|c|c|}
\hline & & & & & & Prog. & Prel. Est. & Proj. & Proj. & Proj. & Proj. \\
\hline & 2001 & 2002 & 2003 & 2003 & 2003 & 2003 & 2003 & 2004 & 2004 & 2004 & 2004 \\
\hline & Dec. & Dec. & Mar. & June & Sept. & Dec. & Dec. & Mar. & Jun. & Sept. & Dec. \\
\hline & \multicolumn{11}{|c|}{ (Stocks in millions of Jordanian dinars) } \\
\hline Net foreign assets & 2,321 & 2,940 & 3,036 & 3,593 & 3,880 & 3,255 & 3,909 & 3,858 & 3,889 & 3,931 & 3,953 \\
\hline Net domestic assets & -513 & $-1,046$ & $-1,036$ & $-1,465$ & $-1,710$ & $-1,222$ & $-1,622$ & $-1,519$ & $-1,501$ & $-1,457$ & $-1,462$ \\
\hline Net claims on government 1 / & 664 & 580 & 608 & 497 & 624 & 242 & 729 & 860 & 643 & 718 & 861 \\
\hline Net claims on NFPEs, local government, and the SSC & -19 & -56 & -40 & -57 & -60 & -40 & -128 & -128 & -128 & -128 & -128 \\
\hline Net claims on financial institutions & 14 & 24 & 23 & 26 & 26 & 23 & 24 & 24 & 24 & 24 & 24 \\
\hline Net claims on private sector & 14 & 15 & 15 & 15 & 15 & 15 & 15 & 15 & 15 & 15 & 15 \\
\hline Net claims on commercial banks & 114 & 121 & 44 & 152 & -16 & 44 & 87 & 87 & 87 & 87 & 87 \\
\hline $\mathrm{CDs}$ & $-1,234$ & $-1,644$ & $-1,624$ & $-1,950$ & $-2,166$ & $-1,444$ & $-2,176$ & $-2,204$ & $-1,969$ & $-2,000$ & $-2,148$ \\
\hline Other items, net (asset: + ) & -66 & -86 & -62 & -146 & -133 & -62 & -172 & -172 & -172 & -172 & -172 \\
\hline Jordanian dinar reserve money & 1,808 & 1,894 & 2,000 & 2,129 & 2,170 & 2,033 & 2,287 & 2,339 & 2,388 & 2,474 & 2,491 \\
\hline Currency & 1,279 & 1,333 & 1,469 & 1,481 & 1,493 & 1,411 & 1,535 & 1,563 & 1,589 & 1,638 & 1,644 \\
\hline Commercial banks' reserves & 529 & 561 & 531 & 647 & 677 & 623 & 751 & 776 & 799 & 836 & 847 \\
\hline \multirow[t]{2}{*}{ Of which: required reserves } & 283 & 322 & 341 & 390 & 424 & 342 & 428 & 439 & 448 & 465 & 469 \\
\hline & \multicolumn{11}{|c|}{ (Cumulative flows in millions of Jordanian dinars from beginning of period) } \\
\hline Net foreign assets & -142 & 619 & 96 & 653 & 940 & 315 & 969 & -51 & -20 & 22 & 44 \\
\hline Net domestic assets & 74 & -533 & 10 & -419 & -664 & -176 & -576 & 103 & 121 & 165 & 160 \\
\hline Net claims on government 1 / & 9 & -85 & 28 & -83 & 45 & -337 & 149 & 131 & -85 & -11 & 132 \\
\hline Net claims on NFPEs, local government, and the SSC & 0 & -37 & 15 & -2 & -4 & 15 & -73 & 0 & 0 & 0 & 0 \\
\hline Net claims on financial institutions & -14 & 10 & -1 & 2 & 2 & -1 & 0 & 0 & 0 & 0 & 0 \\
\hline Net claims on private sector & 1 & 1 & 0 & 0 & 0 & 0 & 1 & 0 & 0 & 0 & 0 \\
\hline Net claims on commercial banks & -141 & 8 & -77 & 31 & -137 & -77 & -35 & 0 & 0 & 0 & 0 \\
\hline CDs & 189 & -410 & 20 & -307 & -523 & 199 & -533 & -28 & 207 & 176 & 28 \\
\hline Other items, net (asset: + ) & 30 & -20 & 25 & -60 & -47 & 25 & -86 & 0 & 0 & 0 & 0 \\
\hline Jordanian dinar reserve money & -68 & 86 & 106 & 235 & 276 & 139 & 393 & 53 & 101 & 187 & 205 \\
\hline Currency & -44 & 54 & 136 & 148 & 160 & 78 & 202 & 28 & 54 & 102 & 109 \\
\hline \multirow[t]{2}{*}{ Commercial banks' reserves } & -24 & 32 & -30 & 86 & 116 & 62 & 190 & 25 & 48 & 85 & 96 \\
\hline & \multicolumn{11}{|c|}{ (Cumulative flows in percent of beginning-of-period reserve money) } \\
\hline Net foreign assets & -7.6 & 34.3 & 5.1 & 34.5 & 49.6 & 16.6 & 51.1 & -2.2 & -0.9 & 1.0 & 1.9 \\
\hline Net domestic assets & 3.9 & -29.5 & 0.5 & -22.1 & -35.1 & -9.3 & -30.4 & 4.5 & 5.3 & 7.2 & 7.0 \\
\hline Net claims on government 1 / & 0.5 & -4.7 & 1.5 & -4.4 & 2.4 & -17.8 & 7.9 & 5.7 & -3.7 & -0.5 & 5.8 \\
\hline Net claims on NFPEs, local government, and the SSC & 0.0 & -2.0 & 0.8 & -0.1 & -0.2 & 0.8 & -3.8 & 0.0 & 0.0 & 0.0 & 0.0 \\
\hline Net claims on financial institutions & -0.7 & 0.6 & -0.1 & 0.1 & 0.1 & -0.1 & 0.0 & 0.0 & 0.0 & 0.0 & 0.0 \\
\hline Net claims on private sector & 0.0 & 0.0 & 0.0 & 0.0 & 0.0 & 0.0 & 0.0 & 0.0 & 0.0 & 0.0 & 0.0 \\
\hline Net claims on commercial banks & -7.5 & 0.4 & -4.1 & 1.6 & -7.2 & -4.1 & -1.8 & 0.0 & 0.0 & 0.0 & 0.0 \\
\hline CDs & 10.0 & -22.7 & 1.1 & -16.2 & -27.6 & 10.5 & -28.1 & -1.2 & 9.0 & 7.7 & 1.2 \\
\hline Other items, net (asset: + ) & 1.6 & -1.1 & 1.3 & -3.2 & -2.5 & 1.3 & -4.5 & 0.0 & 0.0 & 0.0 & 0.0 \\
\hline Jordanian dinar reserve money & -3.6 & 4.8 & 5.6 & 12.4 & 14.6 & 7.4 & 20.7 & 2.3 & 4.4 & 8.2 & 8.9 \\
\hline Currency & -2.4 & 3.0 & 7.2 & 7.8 & 8.4 & 4.1 & 10.7 & 1.2 & 2.3 & 4.5 & 4.7 \\
\hline Commercial banks' reserves & -1.3 & 1.8 & -1.6 & 4.6 & 6.1 & 3.3 & 10.0 & 1.1 & 2.1 & 3.7 & 4.2 \\
\hline \multicolumn{12}{|l|}{ Memorandum items: } \\
\hline Gross usable international reserves (in millions of US\$) & 2,565 & 3,474 & 3,597 & 4,365 & 4,725 & 3,933 & 4,745 & 4,636 & 4,661 & 4,694 & 4,700 \\
\hline As a ratio to JD broad money (in percent) & 30.1 & 38.1 & 38.7 & 45.0 & 46.7 & 40.6 & 46.5 & 44.4 & 43.7 & 42.5 & 42.2 \\
\hline As a ratio of JD reserve money (in percent) & 100.6 & 130.0 & 127.5 & 145.4 & 154.4 & 137.1 & 147.1 & 140.5 & 138.4 & 134.5 & 133.8 \\
\hline NIR in IMF definition 2/ & 1,497 & 2,150 & 2,258 & 2,819 & 3,106 & 2,470 & 3,145 & 3,078 & 3,109 & 3,151 & 3,176 \\
\hline Money multiplier (for Jordanian dinar liquidity) & 3.34 & 3.42 & 3.29 & 3.23 & 3.31 & 3.38 & 3.17 & 3.17 & 3.17 & 3.17 & 3.17 \\
\hline
\end{tabular}

Sources: $\mathrm{CBJ}$; and Fund staff estimates and projections.

1/ Including U.N. compensation funds and WAJ debt assumed by government.

2/ In millions of Jordanian dinars. Excludes foreign assets pledged as collateral for the 1993 commercial debt restructuring and the yearly change in foreign currency swaps. 
Table 5. Summary Balance of Payments, 2000-09 (In millions of U.S. dollars)

\begin{tabular}{|c|c|c|c|c|c|c|c|c|c|c|c|c|}
\hline & 2000 & 2001 & $\begin{array}{l}\text { Prel. } \\
2002\end{array}$ & $\begin{array}{l}\text { Prog. } \\
2003\end{array}$ & $\begin{array}{c}\text { Prel. Est. } \\
2003\end{array}$ & $\begin{array}{l}\text { Prog. } \\
2004\end{array}$ & $\begin{array}{l}\text { Rev. } \\
2004\end{array}$ & $\begin{array}{l}\text { Proj. } \\
2005\end{array}$ & $\begin{array}{l}\text { Proj. } \\
2006\end{array}$ & $\begin{array}{l}\text { Proj. } \\
2007\end{array}$ & $\begin{array}{l}\text { Proj. } \\
2008\end{array}$ & $\begin{array}{l}\text { Proj. } \\
2009\end{array}$ \\
\hline Current account & 59 & -4 & 418 & 446 & 1,090 & 72 & 561 & 177 & 21 & 0 & -18 & -33 \\
\hline Trade balance & $-2,175$ & $-2,007$ & $-1,679$ & $-1,988$ & $-1,931$ & $-2,101$ & $-2,158$ & $-2,331$ & $-2,502$ & $-2,599$ & $-2,788$ & $-3,011$ \\
\hline Exports f.o.b. & 1,899 & 2,294 & 2,772 & 2,772 & 3,000 & 2,945 & 3,249 & 3,437 & 3,667 & 3,887 & 4,160 & 4,450 \\
\hline Imports f.o.b. & 4,074 & 4,301 & 4,450 & 4,760 & 4,931 & 5,046 & 5,407 & 5,768 & 6,169 & 6,486 & 6,948 & 7,460 \\
\hline Services (net) & -86 & -243 & -272 & -437 & -258 & -468 & -290 & -299 & -301 & -279 & -249 & -190 \\
\hline of which: travel (net) & 336 & 280 & 368 & 279 & 437 & 287 & 473 & 517 & 572 & 642 & 731 & 848 \\
\hline Income (net) & 135 & 187 & 111 & 92 & 123 & 219 & 208 & 364 & 430 & 441 & 451 & 459 \\
\hline of which: investment income (net) & -27 & 9 & -79 & -99 & -76 & 14 & 2 & 151 & 205 & 203 & 198 & 190 \\
\hline of which: compensation of employees (net) & 161 & 178 & 190 & 190 & 199 & 204 & 206 & 213 & 225 & 238 & 253 & 269 \\
\hline Current transfers (net) & 2,184 & 2,059 & 2,259 & 2,779 & 3,156 & 2,422 & 2,801 & 2,443 & 2,394 & 2,438 & 2,568 & 2,709 \\
\hline Public (net) & 405 & 461 & 507 & 1,086 & 1,266 & 614 & 961 & 562 & 407 & 338 & 338 & 341 \\
\hline Private (net) & 1,780 & 1,598 & 1,752 & 1,693 & 1,890 & 1,808 & 1,840 & 1,881 & 1,987 & 2,100 & 2,230 & 2,368 \\
\hline of which: U.N. compensation 1/ & 529 & 68 & 76 & 18 & 111 & 0 & 0 & 0 & 0 & 0 & 0 & 0 \\
\hline of which: remittances & 1,485 & 1,643 & 1,751 & 1,753 & 1,837 & 1,883 & 1,916 & 1,962 & 2,075 & 2,193 & 2,331 & 2,477 \\
\hline Capital account & 870 & -89 & -89 & -127 & -29 & -44 & -621 & -225 & -63 & 13 & 320 & 280 \\
\hline Public sector (net) & -360 & -152 & -147 & -256 & -723 & -228 & -512 & -282 & -318 & -240 & -79 & -260 \\
\hline Disbursements & 171 & 342 & 334 & 231 & 178 & 315 & 235 & 245 & 200 & 257 & 386 & 261 \\
\hline Amortization 2/ & 531 & 494 & 481 & 487 & 900 & 543 & 747 & 527 & 518 & 496 & 464 & 521 \\
\hline Private sector (net) & 1,231 & 63 & 58 & 130 & 694 & 184 & -109 & 57 & 255 & 253 & 399 & 540 \\
\hline Direct foreign investment 3/ & 751 & 78 & 35 & 168 & 330 & 177 & 96 & 102 & 100 & 170 & 250 & 250 \\
\hline Portfolio and other capital flows & 104 & -113 & 18 & 7 & 347 & 7 & -205 & -45 & 155 & 83 & 149 & 290 \\
\hline Errors and omissions & 376 & 97 & 4 & -45 & 17 & 0 & 0 & 0 & 0 & 0 & 0 & 0 \\
\hline Overall balance & 929 & -94 & 329 & 319 & 1,061 & 28 & -60 & -48 & -42 & 13 & 302 & 247 \\
\hline Financing & -929 & 94 & -329 & -319 & $-1,061$ & -27 & 60 & 47 & 42 & -13 & -302 & -247 \\
\hline Increase in NFA (-) 4/ & $-1,198$ & -185 & -613 & -535 & $-1,254$ & -243 & -174 & -141 & -124 & -132 & -273 & -258 \\
\hline Central bank 3/ & -665 & 290 & -886 & -330 & $-1,267$ & -36 & 37 & 79 & 127 & 138 & 15 & 50 \\
\hline Commercial banks & -533 & -475 & 272 & -204 & 13 & -207 & -210 & -220 & -252 & -269 & -288 & -308 \\
\hline Fund credit (net) & -11 & -13 & 12 & -94 & -100 & -90 & -99 & -78 & -87 & -79 & -56 & -23 \\
\hline Arab Monetary Fund (net) & -17 & 1 & -15 & -9 & -9 & -10 & -11 & -9 & 0 & 0 & 0 & 0 \\
\hline Relief from debt operations $5 /$ & 97 & 86 & 69 & 46 & 28 & 45 & 45 & 41 & 37 & 0 & 0 & 0 \\
\hline Debt rescheduling & 200 & 204 & 218 & 273 & 273 & 271 & 298 & 235 & 216 & 198 & 28 & 34 \\
\hline Financing gap & 0 & 0 & 0 & 0 & 0 & 0 & 0 & 0 & 0 & 0 & 0 & 0 \\
\hline \multicolumn{13}{|l|}{ Memorandum items: } \\
\hline Gross international reserves & 2,742 & 2,565 & 3,474 & 3,913 & 4,745 & 3,950 & 4,700 & 4,664 & 4,563 & 4,443 & 4,435 & 4,408 \\
\hline In months of prospective imports GNFS 6/ & 6.4 & 6.0 & 7.8 & 8.0 & 9.7 & 7.6 & 9.0 & 8.3 & 7.7 & 6.9 & 6.6 & 6.1 \\
\hline In months of current merchandise imports & 8.9 & 7.9 & 10.8 & 11.0 & 13.4 & 10.4 & 12.0 & 11.1 & 10.1 & 9.3 & 8.6 & 7.9 \\
\hline Annual merchandise export growth, percent & 3.7 & 20.8 & 20.8 & 1.0 & 8.2 & 6.2 & 8.3 & 5.8 & 6.7 & 6.0 & 7.0 & 7.0 \\
\hline Domestic exports & 2.8 & 25.1 & 15.1 & 5.9 & 5.3 & 7.7 & 10.1 & 6.7 & 7.8 & 6.9 & 8.1 & 8.0 \\
\hline Export of GNFS growth, percent & 0.1 & 6.8 & 13.4 & -3.1 & 3.4 & 6.2 & 8.1 & 6.3 & 7.2 & 6.9 & 7.9 & 8.3 \\
\hline Import growth, percent & 23.7 & 5.6 & 3.5 & 7.8 & 10.8 & 6.0 & 9.7 & 6.7 & 6.9 & 5.1 & 7.1 & 7.4 \\
\hline Excluding oil & 18.8 & 7.1 & 1.4 & 6.7 & 8.5 & 9.3 & 11.3 & 8.9 & 7.7 & 7.7 & 7.7 & 7.5 \\
\hline Import of GNFS growth, percent & 15.5 & 3.8 & 4.2 & 6.4 & 5.0 & 6.1 & 9.3 & 6.7 & 7.0 & 5.5 & 7.2 & 7.4 \\
\hline \multicolumn{13}{|l|}{ Current account balance } \\
\hline in percent of GDP & 0.7 & 0.0 & 4.5 & 4.6 & 11.1 & 0.7 & 5.3 & 1.6 & 0.2 & 0.0 & -0.1 & -0.2 \\
\hline GDP (in millions of U.S.dollars) & 8,447 & 8,901 & 9,383 & 9,726 & 9,860 & 10,448 & 10,612 & 11,397 & 12,298 & 13,271 & 14,320 & 15,452 \\
\hline
\end{tabular}

Sources: Jordanian authorities; and Fund staff estimates.

1/ U.N. compensation to Jordanian residents for personal and business losses related to the Gulf war.

2/ Includes the face value of debt reduction from debt restructuring operations, as well as a buyback of all of Jordan's Par Brady bonds in December 2003 .

In 2004, allows for the early repayment of US $\$ 250$ million of higher interest external debt.

3/ Includes the proceeds for US\$170 million from the privatization of 26 percent of the Arab Potash Company for October 2003

4/ The change in Fund credit outstanding is deducted from the change in NFA from monetary survey.

5/ The difference between the face value of debt reduction the cost of debt operations.

6/ In months of prospective import of goods and non-factor services for the following 12 months, excluding imports for re-exports.

7/ In terms of expected full year GDP. 
Table 6. Jordan: Total Government and Government-Guaranteed Debt, 2000-09

\begin{tabular}{|c|c|c|c|c|c|c|c|c|c|c|}
\hline & $\begin{array}{c}2000 \\
\text { Dec }\end{array}$ & $\begin{array}{l}2001 \\
\text { Dec. }\end{array}$ & $\begin{array}{c}2002 \\
\text { Dec }\end{array}$ & $\begin{array}{c}\text { Prel. Est. } \\
2003 \\
\text { Dec }\end{array}$ & $\begin{array}{l}\text { Proj. } \\
2004 \\
\text { Dec. }\end{array}$ & $\begin{array}{l}\text { Proj. } \\
2005 \\
\text { Dec. }\end{array}$ & $\begin{array}{l}\text { Proj. } \\
2006 \\
\text { Dec. }\end{array}$ & $\begin{array}{l}\text { Proj. } \\
2007 \\
\text { Dec. }\end{array}$ & $\begin{array}{l}\text { Proj. } \\
2008 \\
\text { Dec. }\end{array}$ & $\begin{array}{l}\text { Proj. } \\
2009 \\
\text { Dec. }\end{array}$ \\
\hline & \multicolumn{10}{|c|}{ (In millions of Jordanian dinars) } \\
\hline \multicolumn{11}{|l|}{ Domestic debt } \\
\hline Gross debt & 1,235 & 1,397 & 1,656 & 1,815 & 1,982 & 2,080 & 2,174 & 2,351 & 2,381 & 2,430 \\
\hline Net debt & 944 & 1,152 & 1,335 & 1,703 & 1,870 & 1,968 & 2,062 & 2,239 & 2,269 & 2,318 \\
\hline External debt (government and government-guaranteed) & 4,795 & 4,743 & 5,125 & 5,392 & 5,128 & 5,040 & 4,914 & 4,830 & 4,760 & 4,613 \\
\hline \multicolumn{11}{|l|}{ Total } \\
\hline Gross domestic and external debt & 6,030 & 6,140 & 6,781 & 7,207 & 7,110 & 7,120 & 7,088 & 7,181 & 7,140 & 7,044 \\
\hline \multirow[t]{2}{*}{ Net domestic and external debt } & 5,739 & 5,895 & 6,460 & 7,095 & 6,998 & 7,008 & 6,976 & 7,069 & 7,028 & 6,932 \\
\hline & \multicolumn{10}{|c|}{ (In percent of GDP) } \\
\hline \multicolumn{11}{|l|}{ Domestic debt } \\
\hline Gross debt & 20.6 & 22.1 & 24.9 & 26.0 & 26.3 & 25.7 & 24.9 & 25.0 & 23.4 & 22.2 \\
\hline Net debt & 15.8 & 18.3 & 20.1 & 24.4 & 24.9 & 24.4 & 23.7 & 23.8 & 22.3 & 21.2 \\
\hline External debt (government and government-guaranteed) & 80.1 & 75.2 & 77.0 & 77.1 & 68.2 & 62.4 & 56.4 & 51.3 & 46.9 & 42.1 \\
\hline \multicolumn{11}{|l|}{ Total } \\
\hline Gross domestic and external debt & 100.7 & 97.3 & 101.9 & 103.1 & 94.5 & 88.1 & 81.3 & 76.3 & 70.3 & 64.3 \\
\hline Net domestic and external debt & 95.8 & 93.4 & 97.1 & 101.5 & 93.0 & 86.7 & 80.0 & 75.1 & 69.2 & 63.3 \\
\hline
\end{tabular}


Table 7. Medium-Term External Debt and Debt Service, 2000-2009

\begin{tabular}{|c|c|c|c|c|c|c|c|c|c|c|}
\hline & 2000 & 2001 & 2002 & $\begin{array}{l}\text { Prel. } \\
2003\end{array}$ & $\begin{array}{l}\text { Proj. } \\
2004\end{array}$ & $\begin{array}{l}\text { Proj. } \\
2005\end{array}$ & $\begin{array}{l}\text { Proj. } \\
2006\end{array}$ & $\begin{array}{l}\text { Proj. } \\
2007\end{array}$ & $\begin{array}{l}\text { Proj. } \\
2008\end{array}$ & $\begin{array}{l}\text { Proj. } \\
2009\end{array}$ \\
\hline & \multicolumn{10}{|c|}{ (In millions of Jordanian dinars) } \\
\hline Total government external debt 1 / & 5,150 & 5,067 & 5,447 & 5,391 & 5,127 & 5,040 & 4,913 & 4,830 & 4,760 & 4,613 \\
\hline excl. market value of Brady collateral & 5,043 & 4,969 & 5,350 & 5,391 & 5,127 & 5,040 & 4,913 & 4,830 & 4,760 & 4,613 \\
\hline \multirow[t]{2}{*}{ excl. collateralized Brady bonds } & 4,795 & 4,743 & 5,123 & 5,391 & 5,127 & 5,040 & 4,913 & 4,830 & 4,760 & 4,613 \\
\hline & \multicolumn{10}{|c|}{ (In millions of U.S. dollars) } \\
\hline Total government external debt 1 / & 7,263 & 7,146 & 7,683 & 7,604 & 7,232 & 7,109 & 6,930 & 6,812 & 6,713 & 6,507 \\
\hline excl. market value of Brady collateral & 7,113 & 7,009 & 7,546 & 7,604 & 7,232 & 7,109 & 6,930 & 6,812 & 6,713 & 6,507 \\
\hline excl. collateralized Brady bonds & 6,763 & 6,689 & 7,226 & 7,604 & 7,232 & 7,109 & 6,930 & 6,812 & 6,713 & 6,507 \\
\hline Of which: obligations existing as of end-1999 & 7,263 & 7,146 & 7,683 & 7,412 & 6,506 & 5,912 & 5,329 & 4,783 & 4,317 & 3,885 \\
\hline Medium- and long-term debt & 6,802 & 6,713 & 7,203 & 7,183 & 6,907 & 6,861 & 6,768 & 6,729 & 6,687 & 6,504 \\
\hline To bilateral and multilateral creditors $1 /$ & 6,126 & 6,116 & 6,633 & 7,092 & 6,869 & 6,837 & 6,748 & 6,713 & 6,672 & 6,490 \\
\hline To London Club creditors & 551 & 497 & 492 & 25 & 15 & 4 & 3 & 2 & 2 & 2 \\
\hline Of which: collateralized Brady bonds & 501 & 457 & 457 & 0 & 0 & 0 & 0 & 0 & 0 & 0 \\
\hline To other creditors & 124 & 101 & 78 & 66 & 23 & 20 & 17 & 14 & 13 & 12 \\
\hline Use of Fund resources & 462 & 433 & 483 & 421 & 325 & 248 & 162 & 83 & 26 & 3 \\
\hline Service on government external debt 1 / & 730 & 769 & 799 & 866 & 847 & 840 & 843 & 855 & 807 & 848 \\
\hline Of which: to the Fund & 55 & 72 & 94 & 112 & 107 & 85 & 92 & 82 & 58 & 24 \\
\hline Amortization & 353 & 437 & 506 & 545 & 562 & 573 & 568 & 576 & 521 & 544 \\
\hline Of which: to the Fund & 31 & 51 & 79 & 100 & 99 & 78 & 87 & 79 & 56 & 23 \\
\hline Interest & 377 & 332 & 293 & 321 & 285 & 266 & 275 & 280 & 286 & 304 \\
\hline \multirow[t]{2}{*}{ Of which: to the Fund } & 24 & 20 & 14 & 12 & 9 & 7 & 5 & 3 & 2 & 1 \\
\hline & \multicolumn{10}{|c|}{ (In percent of GDP) } \\
\hline Total government external debt 1 / & 86.0 & 80.3 & 81.9 & 77.1 & 68.2 & 62.4 & 56.4 & 51.3 & 46.9 & 42.1 \\
\hline excl. market value of Brady collateral & 84.2 & 78.7 & 80.4 & 77.1 & 68.2 & 62.4 & 56.4 & 51.3 & 46.9 & 42.1 \\
\hline excl. collateralized Brady bonds & 80.1 & 75.2 & 77.0 & 77.1 & 68.2 & 62.4 & 56.4 & 51.3 & 46.9 & 42.1 \\
\hline Medium- and long-term debt & 80.5 & 75.4 & 76.8 & 72.9 & 65.1 & 60.2 & 55.0 & 50.7 & 46.7 & 42.1 \\
\hline Use of Fund resources & 5.5 & 4.9 & 5.1 & 4.3 & 3.1 & 2.2 & 1.3 & 0.6 & 0.2 & 0.0 \\
\hline Service on government external debt $1 /$ & 8.6 & 8.6 & 8.5 & 8.8 & 8.0 & 7.4 & 6.9 & 6.4 & 5.6 & 5.5 \\
\hline Amortization & 4.2 & 4.9 & 5.4 & 5.5 & 5.3 & 5.0 & 4.6 & 4.3 & 3.6 & 3.5 \\
\hline \multirow[t]{2}{*}{ Interest } & 4.5 & 3.7 & 3.1 & 3.3 & 2.7 & 2.3 & 2.2 & 2.1 & 2.0 & 2.0 \\
\hline & \multicolumn{10}{|c|}{ (In percent of exports of goods and nonfactor services) } \\
\hline Total government external debt 1 / & 205.4 & 189.2 & 179.3 & 171.6 & 150.9 & 139.6 & 126.9 & 116.7 & 106.5 & 95.3 \\
\hline excl. market value of Brady collateral & 201.2 & 185.6 & 176.1 & 171.6 & 150.9 & 139.6 & 126.9 & 116.7 & 106.5 & 95.3 \\
\hline excl. collateralized Brady bonds & 191.2 & 177.1 & 168.7 & 171.6 & 150.9 & 139.6 & 126.9 & 116.7 & 106.5 & 95.3 \\
\hline Of which: to the Fund & 13.1 & 11.5 & 11.3 & 9.5 & 6.8 & 4.9 & 3.0 & 1.4 & 0.4 & 0.0 \\
\hline Service on government external debt 1 / & 20.6 & 20.4 & 18.7 & 19.5 & 17.7 & 16.5 & 15.4 & 14.7 & 12.8 & 12.4 \\
\hline Of which: to the Fund & 1.6 & 1.9 & 2.2 & 2.5 & 2.2 & 1.7 & 1.7 & 1.4 & 0.9 & 0.3 \\
\hline Amortization & 10.0 & 11.6 & 11.8 & 12.3 & 11.7 & 11.3 & 10.4 & 9.9 & 8.3 & 8.0 \\
\hline Of which: to the Fund & 0.9 & 1.4 & 1.9 & 2.3 & 2.1 & 1.5 & 1.6 & 1.4 & 0.9 & 0.3 \\
\hline Interest & 10.7 & 8.8 & 6.8 & 7.2 & 6.0 & 5.2 & 5.0 & 4.8 & 4.5 & 4.5 \\
\hline Of which: to the Fund & 0.7 & 0.5 & 0.3 & 0.3 & 0.2 & 0.1 & 0.1 & 0.1 & 0.0 & 0.0 \\
\hline
\end{tabular}

Sources: Jordanian authorities; and Fund staff estimates and projections.

$1 /$ Includes government guaranteed external debt. 
Table 8. Jordan: Indicators of Financial Vulnerability, 2000-04

(End of period, unless otherwise noted)

\begin{tabular}{|c|c|c|c|c|c|}
\hline & 2000 & 2001 & 2002 & $\begin{array}{l}\text { Prel. } \\
2003\end{array}$ & $\begin{array}{l}\text { Proj. } \\
2004 \\
\end{array}$ \\
\hline \multicolumn{6}{|l|}{ Monetary and financial indicators } \\
\hline Gross domestic currency public debt (in percent of GDP) & 19.3 & 22.1 & 24.9 & 26.0 & 26.3 \\
\hline Central government net domestic currency borrowing requirement (in percent of GDP) & -1.0 & 2.3 & 2.6 & 4.4 & 2.2 \\
\hline Broad money (annual growth, in percent) & 10.2 & 5.8 & 7.0 & 11.0 & 8.5 \\
\hline Broad domestic currency liquidity (M2) (annual growth, in percent) & 7.1 & 3.3 & 7.0 & 11.9 & 8.9 \\
\hline Private sector credit (annual growth, in percent) & 4.5 & 11.3 & 3.2 & 3.5 & 11.4 \\
\hline \multicolumn{6}{|l|}{ Banking sector indicators } \\
\hline Problem loans (as percent of capital and reserves) & 92.9 & 102.1 & 114.4 & $\ldots$ & $\ldots$ \\
\hline Provisions against problem loans (as percent of problem loans) & 34.6 & 36.4 & 36.6 & $\ldots$ & $\ldots$ \\
\hline Risk-weighted capital adequacy ratio (in percent) & 19.4 & 17.4 & 16.7 & $\ldots$ & $\ldots$ \\
\hline Share of construction loans in total private credit (in percent) & 18.6 & 16.4 & 16.7 & 17.2 & $\ldots$ \\
\hline Credit to private sector (in percent of GDP) & 66.8 & 70.6 & 68.9 & 66.8 & $\cdots$ \\
\hline \multicolumn{6}{|l|}{ Foreign currency and external debt indicators } \\
\hline Gross foreign currency public debt (in millions of U.S. dollars) & 6,763 & 6,689 & 7,228 & 7,605 & 7,232 \\
\hline Gross external public debt (in millions of U.S. dollars) & 6,763 & 6,689 & 7,228 & 7,605 & 7,232 \\
\hline In percent of GDP & 80.1 & 75.2 & 77.0 & 77.1 & 68.2 \\
\hline Short-term external debt (in millions of U.S. dollars) $1 /$ & 353 & 437 & 506 & 545 & 812 \\
\hline Total foreign liabilities of central bank (in millions of U.S. dollars) & 598 & 592 & 607 & 503 & 474 \\
\hline Total foreign liabilities of commercial banks (in millions of U.S. dollars) & 3,629 & 4,213 & 4,718 & 5,048 & 5,402 \\
\hline Commercial banks' net foreign asset position (in millions of U.S. dollars) & 1,379 & 1,891 & 1,619 & 1,631 & 1,677 \\
\hline \multicolumn{6}{|l|}{ Official reserves indicators } \\
\hline Gross usable reserves (in millions of U.S. dollars) 2/ & 2,742 & 2,565 & 3,474 & 4,745 & 4,700 \\
\hline In percent of $\mathrm{M} 2$ & 26.2 & 23.1 & 29.3 & 36.0 & 32.9 \\
\hline In percent of short-term external debt by remaining maturity & 776.6 & 587.5 & 685.8 & 870.9 & 579.0 \\
\hline Net international reserves (in millions of U.S. dollars) 2/ & 2,275 & 2,111 & 3,032 & 4,479 & 4,479 \\
\hline In percent of $\mathrm{M} 2$ & 21.7 & 19.0 & 25.5 & 34.0 & 31.3 \\
\hline In percent of short-term external debt & 644.3 & 483.6 & 598.6 & 822.1 & 551.7 \\
\hline \multicolumn{6}{|l|}{ External current account indicators (annual flows) } \\
\hline Merchandise exports, f.o.b. (in millions of U.S. dollars) & 1,899 & 2,294 & 2,772 & 3,000 & 3,249 \\
\hline Annual changes in percent & 3.7 & 20.8 & 20.8 & 8.2 & 8.3 \\
\hline Merchandise imports, f.o.b. (in millions of U.S. dollars) & 4,074 & 4,301 & 4,450 & 4,931 & 5,407 \\
\hline Annual changes in percent & 23.7 & 5.6 & 3.5 & 10.8 & 9.7 \\
\hline Current account balance (including grants, in millions of U.S. dollars) & 59 & -4 & 418 & 1,090 & 561 \\
\hline In percent of GDP & 0.7 & 0.0 & 4.5 & 11.1 & 5.3 \\
\hline
\end{tabular}

Sources: Data provided by the authorities; Bank for International Settlements; IMF, World Economic Outlook; and Fund staff estimates and projections.

1/ Short-term public debt is defined as non-resident treasury bill holdings and debt coming due during next 12 months.

2/ Excluding foreign currency deposits held by commercial banks with the central bank. 
Table 9. Jordan: Indicators of Bank Soundness, 1998-2003

End of Period

\begin{tabular}{rrrrrrr}
\multicolumn{8}{c}{ End of Period } \\
\hline \multirow{2}{*}{1998} & 1999 & 2000 & $20014 /$ & 2002 & 2003 \\
\hline
\end{tabular}

(In millions of Jordanian dinars)

Total assets

Total loans

Total capital

Capital and reserves 1/

Classified loans 2/

Provisions against classified loans $3 /$

Total assets in foreign currency

Of which: loans to residents in foreign currency

Total liabilities in foreign currencies

Of which : non-resident deposits

Net profits (after tax) 4/

Total capital/total assets

Capital and reserves/total assets

Risk-weighted capital ratio

Classified loans/total loans

Provisions/classified loans

Net profits/total assets

Net profits/total loans

$\begin{array}{rrrrrr}9,869 & 10,990 & 12,387 & 13,630 & 14,602 & 14,725 \\ 4,066 & 4,267 & 4,367 & 4,771 & 4,955 & 5,045 \\ 572 & 570 & 601 & 617 & 642 & 659 \\ 841 & 856 & 865 & 902 & 912 & 933 \\ & & & & & \\ 450 & 613 & 804 & 921 & 1,043 & 1,075 \\ 206 & 274 & 278 & 335 & 382 & 396 \\ & & & & & \\ 3,349 & 3,786 & 4,580 & 5,211 & 5,640 & 5,408 \\ 347 & 384 & 402 & 478 & 569 & 622 \\ 3,267 & 3,639 & 4,428 & 5,015 & 5,485 & 5,218 \\ 1,520 & 1,546 & 1,658 & 1,713 & 1,898 & 1,713 \\ & & & & & \\ 72 & 30 & 38 & 98 & 80 & 55\end{array}$

(In percent)

$\begin{array}{rrrrrr}5.8 & 5.2 & 4.9 & 4.5 & 4.4 & 4.5 \\ 8.5 & 7.9 & 7.0 & 6.6 & 6.2 & 6.3 \\ 21.7 & 21.2 & 19.4 & 17.4 & 16.7 & 17.1 \\ & & & & & \\ 11.1 & 14.4 & 18.4 & 19.3 & 21 & 21.3 \\ 45.8 & 44.7 & 34.6 & 36.4 & 36.6 & 36.8 \\ & & & & & \\ 0.7 & 0.3 & 0.3 & 0.7 & 0.5 & 0.4 \\ 1.8 & 0.7 & 0.9 & 2.1 & 1.6 & 1.1\end{array}$

Source: Central Bank of Jordan.

1/ Capital and reserves are defined according to the capital adequacy definition of 1997.

2/ Loans at least 180 days overdue until 1999, then 150 days due for 2000, and 120 days due for 2001.

3/ Provisions against classified loans in the year 2000 declined by JD 40 million due to a revised treatment of the provisions of one of the banks.

4/ With the agreement of the Central Bank of Jordan, no provisions were taken for the troubled banks pending a court resolution. 
Table 10. Jordan: Indicators of Fund Credit, 2000-10

(In millions of SDR)

\begin{tabular}{|c|c|c|c|c|c|c|c|c|c|c|c|}
\hline & \multirow[b]{2}{*}{2000} & \multirow[b]{2}{*}{2001} & \multirow[b]{2}{*}{2002} & \multirow[b]{2}{*}{2003} & \multicolumn{7}{|c|}{ Projections } \\
\hline & & & & & 2004 & 2005 & 2006 & 2007 & 2008 & 2009 & 2010 \\
\hline \multicolumn{12}{|l|}{ Total Fund credit outstanding at end-period } \\
\hline In millions of SDR & 354.3 & 344.5 & 355.0 & 283.6 & 217.5 & 165.3 & 107.7 & 55.0 & 17.5 & 2.1 & 0.0 \\
\hline In millions of U.S. dollars & 461.6 & 432.9 & 482.6 & 395.1 & 301.4 & 228.6 & 148.7 & 75.8 & 24.0 & 2.9 & 0.0 \\
\hline \multicolumn{12}{|l|}{ In percent of: } \\
\hline Quota & 207.8 & 202.1 & 208.2 & 166.3 & 127.5 & 96.9 & 63.1 & 32.3 & 10.2 & 1.2 & 0.0 \\
\hline GDP & 5.5 & 4.9 & 5.1 & 4.0 & 2.8 & 2.0 & 1.2 & 0.6 & 0.2 & 0.0 & 0.0 \\
\hline Exports of goods and nonfactor services & 13.1 & 11.5 & 11.3 & 8.9 & 6.3 & 4.5 & 2.7 & 1.3 & 0.4 & 0.0 & 0.0 \\
\hline Public and publicly guaranteed debt & 6.4 & 6.1 & 6.3 & 5.2 & 4.2 & 3.2 & 2.0 & 1.0 & 0.3 & 0.0 & 0.0 \\
\hline \multicolumn{12}{|l|}{ Transactions under the GRA } \\
\hline Purchases under the GRA & 15.2 & 30.5 & 71.5 & 0.0 & 0.0 & 0.0 & 0.0 & 0.0 & 0.0 & 0.0 & 0.0 \\
\hline Repurchases & 23.8 & 40.2 & 61.0 & 71.4 & 66.1 & 52.2 & 57.6 & 52.7 & 37.5 & 15.4 & 2.1 \\
\hline Net Purchases & -8.6 & -9.8 & 10.5 & -71.4 & -66.1 & -52.2 & -57.6 & -52.7 & -37.5 & -15.4 & -2.1 \\
\hline Charges and interest & 18.2 & 16.1 & 11.1 & 8.7 & 5.8 & 4.4 & 3.4 & 2.1 & 1.2 & 0.5 & 0.3 \\
\hline \multicolumn{12}{|l|}{ Debt service to the Fund } \\
\hline In millions of SDR & 42.0 & 56.3 & 72.1 & 80.1 & 71.9 & 56.6 & 61.0 & 54.8 & 38.7 & 15.8 & 2.4 \\
\hline In millions of U.S. dollars & 55.4 & 71.8 & 93.7 & 111.2 & 99.8 & 78.3 & 84.3 & 75.6 & 53.3 & 21.7 & 3.8 \\
\hline \multicolumn{12}{|l|}{ In percent of: } \\
\hline Exports of goods and nonfactor services & 1.6 & 1.9 & 2.2 & 2.5 & 2.1 & 1.5 & 1.5 & 1.3 & 0.8 & 0.3 & 0.1 \\
\hline Service on public and publicly guaranteed debt & 7.6 & 9.3 & 11.7 & 12.9 & 12.3 & 9.5 & 10.2 & 9.1 & 6.4 & 2.6 & 0.5 \\
\hline
\end{tabular}

Sources: IMF Finance Department; and Fund staff estimates. 
Table 11. Jordan: Original and Revised Schedule of Purchases under the Stand-by Arrangement

\begin{tabular}{|c|c|c|c|c|c|}
\hline \multirow[t]{2}{*}{ Availability Date } & \multicolumn{2}{|c|}{ Original Schedule } & \multicolumn{2}{|c|}{ Revised Schedule } & \multirow[t]{2}{*}{ Conditions for Purchases } \\
\hline & $\begin{array}{l}\text { Millions } \\
\text { of SDR }\end{array}$ & $\begin{array}{c}\text { In percent of } \\
\text { quota }\end{array}$ & $\begin{array}{l}\text { Millions of } \\
\text { SDR }\end{array}$ & $\begin{array}{c}\text { In percent of } \\
\text { quota }\end{array}$ & \\
\hline July 5, 2002 & 10.66 & 6.25 & 10.66 & 6.25 & $\begin{array}{l}\text { Approval of stand-by } \\
\text { arrangement. }\end{array}$ \\
\hline November 15,2002 & --- & $-\overline{--}$ & --- & $\begin{array}{l}-- \\
\end{array}$ & \\
\hline February 15,2003 & --- & $-\overline{--}$ & $-\overline{--}$ & --- & \\
\hline May 15,2003 & --- & --- & --- & --- & \\
\hline Mid July 2003 & 21.32 & 12.50 & --- & 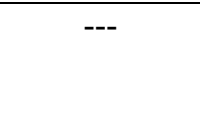 & $\begin{array}{l}\text { Completion of first review } \\
\text { (Authorities did not } \\
\text { purchase). }\end{array}$ \\
\hline August 15, 2003 & 13.32 & 7.81 & --- & --- & \\
\hline November 15, 2003 & 13.33 & 7.82 & --- & --- & \\
\hline March 31, 2004 & 13.32 & 7.81 & 61.29 & 35.94 & $\begin{array}{l}\text { Completion of second } \\
\text { review } \\
\text { (Authorities do not plan to } \\
\text { purchase). }\end{array}$ \\
\hline May 15,2004 & 13.33 & 7.82 & 13.33 & 7.81 & $\begin{array}{l}\text { Observance of end-March } \\
2004 \text { performance criteria } \\
\text { and third review. }\end{array}$ \\
\hline Total & 85.28 & 50.00 & 85.28 & 50.00 & \\
\hline
\end{tabular}




\section{Performance Criteria}

Net international reserves of the CBJ $1 /$

Net domestic assets of the CBJ 2/ 3/

\begin{tabular}{|c|c|c|c|c|c|}
\hline & End-June & & & Septembe & nd-D \\
\hline 2003 & Adjusted & Actual & 2003 & Adjusted & \\
\hline rogram & Program & & Program & Program & \\
\hline
\end{tabular}

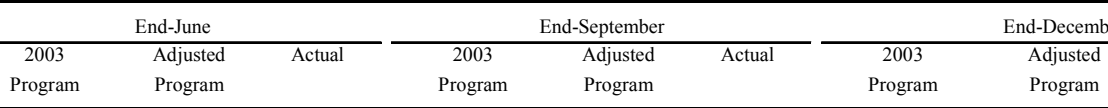

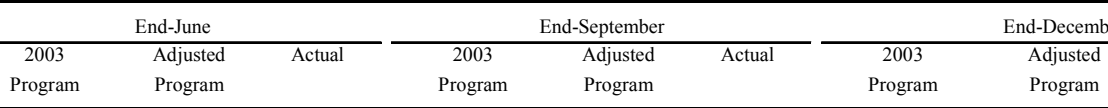

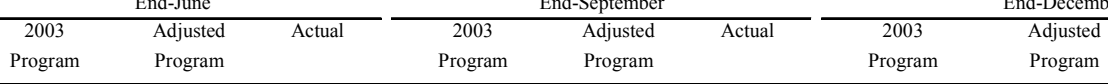

(Cumulative flows from January 1, in millions of Jordanian dinars)

Overall fiscal deficit after grants of the central government 4/ 5/ 6/

Outstanding stock of government and government-

guaranteed short-term external debt (ceiling)

Contracting or guaranteeing of new non-concessional medium-

and long-term external debt by the government (ceiling)

Of which : with maturity of more than one year an

up to and including five years

Non-accumulation of external payment arrears 7

\section{Memorandum item}

Programmed sum of foreign grants, net external financing

of the budget (excluding project loans) and privatization

proceeds from abroad

Programmed foreign grants 8/

Programmed expenditure associated with debt swap

with official bilateral creditors
61

0

133

$\begin{array}{rr}63 & 30 \\ -147 & -115\end{array}$

661

$-419$

0

$-62$

$-172$

139

949

$-665$

106

$-153$

$-83$

988

(Cumulative flows from January 1, in millions of U.S. dollars)

0

499

623

$$
0
$$

156

25

200

(Cumulative flows from January 1, in millions of Jordanian dinars)

Source: Quarterly macroeconomic program.

1/ These floors will adjusted upward (downward) by the extent to which the actual sum of foreign grants and net external financing of the central government (excluding project-related loans and privatization proceeds from abroad) received during 2003 exceeds (falls short of) the levels specified above.

2/ These ceilings will be adjusted upward (downward) by the extent to which the floors on the net international reserves of the CBJ are adjusted downward (upward) due to shortfalls (excesses) in the sum of foreign grants and net external financing of the central government (excluding project-related loans and privatization proceeds from abroad) received during 2003, compared to the levels specified above.

3/ These ceilings will be adjusted downward (upward) by the extent to which the CBJ decreases (increases) reserve requirements on Jordanian dinar deposits of the banking system. The adjustment will equal the change in the required reserve ratio multiplied by the stock of deposits at licensed banks at the start of the month when the new reserve requirement ratio applies that are: (i) denominated in Jordanian dinars; and (ii) subject to reserve

requirements.

4/ These ceilings will be adjusted upward by the extent to which expenditure associated with debt swaps with official bilateral creditors exceeds the amount specified above.

5/ These ceilings will be adjusted downward by the Jordanian dinar equivalent of the second tranche of the extraordinary U.S. grant to the Jordanian government (\$200 million), in the event the tranche is disbursed in 2003.

6/ These ceilings will be adjusted upward by the amount of recapitalization bonds at market interest rates placed by the government with the troubled banks discussed in Section II of the MEFP, up to a maximum amount of JD 100 million.

7/ Continuous performance criterion.

8/ Excludes technical assistance grants channeled through the Ministry of Planning. 
Table 13. Jordan-Structural Performance Criteria and Benchmarks Under the Stand-By Arrangement, 2002-04

\begin{tabular}{|c|c|}
\hline I. Structural Performance Criteria & Status \\
\hline $\begin{array}{l}\text { Issue regulations to enroll all new military recruits in the pension } \\
\text { plan administered by the Social Security Corporation (end- } \\
\text { December 2002). }\end{array}$ & Waived. Done in March 2003 \\
\hline $\begin{array}{l}\text { Implement criteria for disability pensions financed by the central } \\
\text { government budget that are consistent with those applied by the } \\
\text { Social Security Corporation for its members (end-December } \\
\text { 2002). }\end{array}$ & Waived. Done in February 2004 \\
\hline II. Structural Benchmarks & Status \\
\hline $\begin{array}{l}\text { Develop a risk-based audit plan based on different audit } \\
\text { techniques as recommended by the FAD technical assistance } \\
\text { mission to audit GST filers (end-September 2002). }\end{array}$ & Done in October 2002 \\
\hline $\begin{array}{l}\text { Reduce the number of nonfilers to } 10 \text { percent of the registered } \\
\text { taxpayer population by establishing a nonfiler enforcement } \\
\text { program in the GST Department (end-December 2002). }\end{array}$ & Done \\
\hline $\begin{array}{l}\text { Implement a single treasury account system at the central bank } \\
\text { (end-December 2003). }\end{array}$ & Done \\
\hline $\begin{array}{l}\text { Commencing with the } 2003 \text { financial statements, the ministry of } \\
\text { finance, in consultation with the CBJ, will ensure that the } \\
\text { engagement of the external auditor under the bank's new policy of } \\
\text { audit rotation, commencing with the } 2003 \text { financial statements, } \\
\text { will specify that the: (i) audit of the CBJ's financial statements } \\
\text { will be conducted by an internationally recognized audit firm, in } \\
\text { accordance with International Standard on Auditing (ISA); } \\
\text { (ii) external audit opinion will be reviewed (so called "second- } \\
\text { partner-review") by an international partner with International } \\
\text { Accounting Standards (IAS) banking experience from another } \\
\text { region of the international audit firm, who would issue an internal } \\
\text { report to the "signing-partner," which attests the audit has met } \\
\text { international standards (the internal report would be made } \\
\text { available to the Board and Fund staff); and (iii) audit engagement } \\
\text { would be for a term that is greater than one year (e.g., three-to-five } \\
\text { years) (end-December 2003). }\end{array}$ & Done \\
\hline
\end{tabular}


Table 13. Jordan-Structural Performance Criteria and Benchmarks Under the Stand-By Arrangement, 2002-04 (continued)

\begin{tabular}{|l|l|}
\hline $\begin{array}{l}\text { The CBJ will issue regulations to implement prompt corrective } \\
\text { actions that would stipulate automatic penalties for violations of } \\
\text { prudential regulations by banks, in line with the recommendations } \\
\text { of the forthcoming Financial Sector Assessment Program (end- } \\
\text { December 2003). }\end{array}$ & Done in January 2004 \\
\hline $\begin{array}{l}\text { The government will issue a decree to create a single function- } \\
\text { based revenue department by integrating the income tax and sales } \\
\text { tax departments under a single director general reporting to the } \\
\text { minister of finance. In addition, the ministry of finance will create } \\
\text { a temporary integration project directorate to oversee development } \\
\text { and implementation of the large and medium taxpayer offices; the } \\
\text { reform of small taxpayer administration; and the incremental } \\
\text { establishment of an integrated head office (end-March 2004)". }\end{array}$ & In progress \\
\hline $\begin{array}{l}\text { The CBJ will publish: (a) the balance of payments statistics of the } \\
\text { CBJ according to the fifth edition of the Balance of Payments } \\
\text { Manual of the Fund; and (b) the international reserve template } \\
\text { according to Fund methodology (end-May 2004). }\end{array}$ & In progress \\
\hline
\end{tabular}




\section{Jordan: Relations With the Fund}

(As of January 31, 2003)

I. Membership Status: Joined 8/29/52; Article VIII

II. General Resources Account:

Quota

Fund holdings of currency

Reserve position in Fund

III. SDR Department:

Allocation

Net cumulative allocation

Holdings

IV. Outstanding Purchases and Loans:

Stand-by arrangement

Extended arrangements

Contingency and Compensatory

\begin{tabular}{|c|c|}
\hline DR Million & \% Quota \\
\hline 170.50 & 100 \\
\hline 449.7 & 26 \\
\hline 0.0 & \\
\hline
\end{tabular}

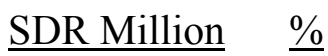

16.89

100.00

2.75

16.28

$\underline{\text { SDR Million }}$

4.26

\% Quota

2.50

264.38

155.06

10.66

\section{Financial Arrangements:}

Type Approval Date Expiration Date Amount Approved Amount Drawn

\begin{tabular}{|c|c|c|c|c|}
\hline & & & (SDR Million) & (SDR Million) \\
\hline BA & $7 / 03 / 02$ & $7 / 02 / 04$ & 85.28 & 10.66 \\
\hline $\mathrm{EFF}$ & $4 / 15 / 99$ & $5 / 31 / 02$ & 127.88 & 127.88 \\
\hline EFF & 2/09/96 & $2 / 08 / 99$ & 238.04 & 202.52 \\
\hline
\end{tabular}

VI. Projected Obligations to Fund (SDR Million; based on existing use of resources and present holdings of SDRs):

\begin{tabular}{|l|c|r|r|r|r|r|}
\hline & $\underline{\text { Overdue }}$ & \multicolumn{5}{|c|}{ Forthcoming } \\
\hline & $\underline{1 / 31 / 04}$ & $\underline{2004}$ & $\underline{2005}$ & $\underline{2006}$ & $\underline{2007}$ & $\underline{2008}$ \\
\hline Principal & -- & 61.83 & 52.17 & 57.61 & 52.28 & 37.52 \\
\hline Charges/Interest & -- & $\underline{5.84}$ & $\underline{4.50}$ & $\underline{3.37}$ & $\underline{2.14}$ & $\underline{1.16}$ \\
\hline Total & -- & 67.67 & 56.67 & 60.99 & 54.42 & 38.68 \\
\hline
\end{tabular}


VII. Safeguard Assessment: Under the Fund's safeguards assessment policy, the Central Bank of Jordan (CBJ) is subject to a full assessment with respect to the Stand-By Arrangement, which was approved on July 3, 2002 and is scheduled to expire on July 2, 2004. The assessment was completed on June 27, 2003 and concluded that the CBJ has made progress in strengthening its safeguards, as recommended in the previous safeguards assessment of May 2001. However, the assessment noted that there are still some unresolved issues at various levels of the bank's operations, including the need for greater transparency in the CBJ's financial statements. Consequently, the assessment proposed a set of measures, which once implemented, could further strengthen the CBJ's operations. Implementation of the recommendations is being monitored by staff.

VIII. Exchange System: The Jordanian dinar is fully convertible and is officially pegged to the SDR. In practice, the authorities have tightly linked its exchange rate to the U.S. dollar since October 1995, at JD $1=\$ 1.41044$.

IX. Article IV Consultation: The 2002 Article IV consultation was concluded by the Executive Board on April 29, 2002. Two FSAP missions visited Jordan in August and September 2003.

X. Technical Assistance: Extensive technical assistance has been provided to Jordan over the years (Table 1).

\section{ROSCs}

Standards or Codes Assessed

Data module

FSSA

Update to data module
Date of Issuance

10/7/2002

$1 / 7 / 2004$

$1 / 30 / 2004$ 
Table 1. Jordan: Technical Assistance, 1999-2003

\begin{tabular}{|c|c|}
\hline Date & Purpose \\
\hline \multicolumn{2}{|l|}{ Fiscal } \\
\hline August 1999 & Income tax reform \\
\hline March 2000 & Pension reform \\
\hline May 2000 & Framework for managing nontreasury accounts \\
\hline September 2000 & Oil pricing mechanism \\
\hline January-April 2002 & Pension reform \\
\hline January-September 2002 & General sales tax reform \\
\hline November 2002 & Macrofiscal capacity and treasury single account \\
\hline February 2003 & Revenue administration reform \\
\hline June 2003 & Peripathetic advisor on single treasury account \\
\hline August 2003 & Peripathetic advisor on single treasury account \\
\hline December 2003 & Peripathetic advisor on single treasury account \\
\hline February 2004 & Peripathetic advisor on revenue administration reform \\
\hline February 2004 & Public expenditure management \\
\hline \multicolumn{2}{|l|}{ Monetary and Financial } \\
\hline August 1999 & Auctions of government securities, and auditing and accounting reform \\
\hline August 1999-August 2000 & Resident expert in banking supervision \\
\hline September 1999-September 2000 & Resident expert in payment system development \\
\hline December 1999 & Development of the domestic and foreign exchange interbank market \\
\hline \multicolumn{2}{|l|}{ Statistical } \\
\hline February 1999 & Preparation of General Data Dissemination System metadata \\
\hline April 1999 & Revision of the PPI sample and PPI calculation \\
\hline September 1999 & NA statistics \\
\hline November 1999 & PPI statistics \\
\hline July 2000 & NA statistics \\
\hline January-February 2002 & Report on the Observation of Standards and Codes - Data Module \\
\hline December 2003 & $\begin{array}{l}\text { Follow-up on Report on the Observation of Standards and Codes-Data } \\
\text { Module }\end{array}$ \\
\hline
\end{tabular}




\section{Jordan-World Bank Group Strategy and Operations}

As of January 31, 2004, Jordan had received 63 World Bank (Bank) loans and 15 IDA credits totaling US $\$ 2,177$ million net of cancellations and terminations. Of the US\$2,177, US\$1,995 has been disbursed to-date. All the credits and 57 of the loans have been fully disbursed. There are seven active projects in the Bank's portfolio for a total of US\$311.7 million. Overall performance of the portfolio both from the perspective of implementation and development impact is good. This reflects the generally good project implementation capacity of Jordanian institutions, Jordan's strong ownership of the program, and the quality of the dialogue between the Bank and the Government of Jordan. The IFC has made cumulative loan and equity investment approvals of US\$262 million and about \$78 million in syndications.

The Joint World Bank-IFC Country Assistance Strategy (CAS) for 2003-05, discussed by the Executive Board in January 2003 addresses the same thematic challenges as the previous CAS. Under the present CAS, the Bank will continue to provide support to the government's key objective, with focus on: (i) private sector development for sustainable growth and job creation: (ii) human development with emphasis on poverty reduction and enabling more Jordanians to participate in the knowledge economy; (iii) improving water resource management and the environment; and (iv) greater gender inclusion in the development process.

The proposed lending ranges from US\$250 million in the base case to US\$325 million in the high case (compared to US\$300 and US\$450 million respectively in the last CAS). Bank lending during the proposed CAS period will concentrate on the focus areas of human resources development (largely education) and public sector reform, which together will account for more than 80 percent of the proposed lending. Bank support for public sector reform and education is a continuation of programmatic Bank support in both areas (Public Sector Reform Loan series and Human Resources Development Sector Investment Loan) reflecting the need for a long-term engagement to address deep, underlying structural issues.

The CAS emphasizes knowledge sharing and capacity building through nonlending assistance. Interventions that disseminate knowledge in the form of international best practice, technical assistance, and economic and sector analysis will play a prominent role in future Bank assistance. For sectors and areas where longer-term Bank engagement is necessary but no lending is currently envisaged, the Bank will focus on a new multi-year analytical and advisory activities that would enable the Bank to support sustained support for policy reform, implementation and institutional development.

World Bank Group support to the private sector development will continue to focus on improving the investment environment, privatization, partial risk guarantees for major projects (envisaged to attract private sector participation and to provide a better financial package for critical projects in water and energy), and, in the case of IFC, direct investment. 
IFC has been active in Jordan for many years and has a current portfolio of US\$109 million in 17 companies. Its role is expected to expand as the investment environment continues to improve and as new opportunities for export-oriented businesses open up in response to the free trade agreement recently concluded with the United States and the association agreement with the European Union. In addition to export-oriented sectors, IFC plans to focus on investments in the financial sectors, infrastructure development, and information technology. 


\section{Jordan: Statistical Issues}

The Fund mission that visited Amman during December 17-21, 2003 prepared an update of the Data module of the Report on the Observance of Standards and Codes (ROSC), which had been published on October 16, 2002. The mission found that important progress had been made in strengthening the statistical system. Jordan is a participant in the General Data Dissemination System and the metadata have been posted on the Dissemination Standards Bulletin Board.

1. As regards real sector data, progress has been made toward implementing the 1993 System of National Accounts, with the compilation of household final consumption expenditures based on the 2002 Household Expenditure and Income Survey (HIES), and supply and use tables. Also, statistics are being compiled and released on a more timely basis, although GDP by expenditure is available at current prices only, and with a lag of more than one year. The main actions taken by the Department of Statistics (DOS) in the area of national accounts statistics, since the 2002 ROSC mission, include:

- Compilation of price indices for imports and exports for the compilation of GDP at constant prices;

- Estimation of household final consumption expenditure based on the 2002 HEIS;

- Updating of supply and use tables for the assessment and valuation of the statistical output;

- Preparation of a study on the revision to the GDP series for 1976-2002;

- Workshops conducted to enhance quality awareness of data providers and users and to monitor users' needs;

- Adoption of a comprehensive training program for national accounts statistics compilers; and

- Dissemination of national accounts data at the two-digit level of ISIC activity.

While the CPI and PPI were considered of good quality by the 2002 Data ROSC mission, DOS has short-term plans for improvements, including:

- Incorporation of owner-occupied dwelling services in the CPI;

- Updating of CPI weights based on the 2002 HIES; and

- Dissemination of regional CPIs.

Recent improvements in government finance statistics have been facilitated by the establishment of a statistical division in the Ministry of Finance (MOF) and the adoption of the Financial Management Reform Project (FMRP). The FMRP is guided by an interministerial committee headed by the Secretary General of the MOF. Important actions already taken include: 
- Compilation of data on the operations of the general government (currently, only data on the budgetary central government are disseminated; the authorities plan to disseminate data on the operations of the general government during 2004); and

- Development of a migration path to the methodology of the Government Finance Statistics 2001 (GFSM 2001).

Some of the actions contemplated in the comprehensive plan to improve the quality of government finance statistics include:

- Dissemination of data on central and general government operations based on the classification and sectorization systems recommended by the GFSM 2001;

- Seeking feedback from users of government finance statistics to monitor their needs;

- Establishment of regular procedures for the verification of internal and intersectoral consistency of government finance statistics;

- Dissemination of a statement on the revision policy, an advance release calendar, and more detailed metadata in the MOF publications and website; and

- Updating of GDDS metadata on a more timely basis.

Monetary data for the CBJ and the commercial banks are reported and published on a monthly basis, with the CBJ's financial statements compiled on an accrual basis. At present, consistency checks between government finance statistics and monetary statistics are not conducted. However, the authorities are considering the establishment of an interagency group to monitor the intersectoral consistency of macroeconomic statistics. Further, actions are being taken to improve the quality of the source data and the methodological soundness of the statistical output. In particular, the $\mathrm{CBJ}$ is:

- Reviewing a new set of report forms for banking institutions, which the Banking Supervision Department has prepared to facilitate better classification and sectorization of the analytical accounts; and

- Promoting the adoption of international accounting standards (IAS) by the commercial banks. Also, the Administrative and Financial and Banking Supervision Departments of the CBJ are in the process of adopting the IAS, in particular with respect to valuation procedures and the recording of financial derivatives within the balance sheet.

With Fund support, the CBJ plans to undertake the following actions to improve the balance of payments (BOP) statistics within the next year:

- Adoption of the BPM5 methodology in the compilation of the BOP statistics and the international investment position (IIP), and dissemination of data in the BPM5 format;

- Dissemination the complete Data Template on International Reserves and International Liquidity; 
- Utilization of further data sources to increase coverage of international transactions of the household and corporate sectors;

- Resolution of most of the existing major gaps in data coverage, including gaps in the financial account statistics and data on international services;

- Development of techniques for systematically analyzing both raw data and statistical aggregates to minimize processing errors;

- Preparation of more comprehensive revision studies on a regular basis to strengthen the statistical process;

- Establishment of procedures for routinely assessing the quality of data, including examination of the causes of estimation errors and revisions;

- Dissemination of the provisions for the confidentiality of individual respondents' data and identification of the BOP Division as the source of the BOP data in the MSB;

- Publication of more detailed BOP metadata and analysis of current developments in the $M S B$ and on the CBJ website;

- Introduction of a regular and continuing program for consultations with users and inform the users of the availability (on request) of more detailed data in the MSB and on the CBJ website;

- Publication of an advanced calendar for the release of BOP statistics in the MSB and on the CBJ website; and

- Updating of the BOP metadata on the GDDS bulletin board on a more timely basis. 
Jordan: Reporting of Main Statistical Indicators

(As of February 29, 2003)

\begin{tabular}{|c|c|c|c|c|c|c|c|c|c|c|c|c|}
\hline & $\begin{array}{l}\text { Exchange } \\
\text { rates }\end{array}$ & $\begin{array}{l}\text { International } \\
\text { reserves }\end{array}$ & $\begin{array}{l}\text { Reserve/ } \\
\text { base } \\
\text { money }\end{array}$ & $\begin{array}{l}\text { Central bank } \\
\text { balance } \\
\text { sheet }\end{array}$ & $\begin{array}{l}\text { Broad } \\
\text { money }\end{array}$ & $\begin{array}{l}\text { Interest } \\
\text { rates }\end{array}$ & $\begin{array}{c}\text { Consumer } \\
\text { price } \\
\text { index }\end{array}$ & $\begin{array}{c}\text { Exports/ } \\
\text { imports }\end{array}$ & $\begin{array}{l}\text { Current } \\
\text { account } \\
\text { balance }\end{array}$ & $\begin{array}{c}\text { Overall } \\
\text { government } \\
\text { balance }\end{array}$ & GDP/GNP & $\begin{array}{c}\text { External } \\
\text { public debt/ } \\
\text { debt service }\end{array}$ \\
\hline $\begin{array}{l}\text { Date of latest } \\
\text { observation }\end{array}$ & $2 / 04$ & $2 / 04$ & $1 / 04$ & $1 / 04$ & $1 / 04$ & $2 / 04$ & $1 / 04$ & $12 / 03$ & Q4/03 & $1 / 04$ & $\mathrm{Q} 3 / 03$ & $1 / 04$ \\
\hline Date received & $2 / / 04$ & $2 / 04$ & $2 / 04$ & $2 / 04$ & $2 / 04$ & $2 / 04$ & $2 / 04$ & $2 / 04$ & $2 / 04$ & $2 / 04$ & $12 / 03$ & $2 / 04$ \\
\hline Frequency of data & W & W & M & M & M & W & M & M & Q & M & Q & $\mathrm{M}$ \\
\hline $\begin{array}{l}\text { Frequency of } \\
\text { publication }\end{array}$ & M & M & M & M & M & M & M & M & Q & M & Q & M \\
\hline $\begin{array}{l}\text { Frequency of } \\
\text { reporting }\end{array}$ & W & W & M & M & M & W & M & Q & Q & M & Q & M \\
\hline $\begin{array}{l}\text { Source of } \\
\text { update }\end{array}$ & $\begin{array}{l}\text { Central Bank } \\
\text { of Jordan } \\
\text { (CBJ) }\end{array}$ & CBJ & CBJ & CBJ & CBJ & CBJ & CBJ & CBJ & CBJ & $\begin{array}{l}\text { Ministry of } \\
\text { Finance } \\
(\mathrm{MoF})\end{array}$ & $\begin{array}{l}\text { Department } \\
\text { of Statistics }\end{array}$ & $\mathrm{MoF}$ \\
\hline $\begin{array}{l}\text { Mode of } \\
\text { reporting }\end{array}$ & E-mail & E-mail & E-mail & E-mail & E-mail & E-mail & $\begin{array}{c}\text { Monthly } \\
\text { Statistical } \\
\text { Bulletin }\end{array}$ & $\begin{array}{c}\text { Monthly } \\
\text { Statistical } \\
\text { Bulletin }\end{array}$ & $\begin{array}{c}\text { Monthly } \\
\text { Statistical } \\
\text { Bulletin }\end{array}$ & $\begin{array}{l}\text { Government } \\
\text { Finance } \\
\text { Bulletin }\end{array}$ & E-mail & $\begin{array}{l}\text { Government } \\
\text { Finance } \\
\text { Bulletin }\end{array}$ \\
\hline Confidentiality & Unrestricted & Unrestricted & Unrestricted & Unrestricted & Unrestricted & Unrestricted & Unrestricted & Unrestricted & Unrestricted & Unrestricted & Unrestricted & Unrestricted \\
\hline Published data & $\begin{array}{l}\text { Monthly } \\
\text { Statistical } \\
\text { Bulletin }\end{array}$ & $\begin{array}{l}\text { Monthly } \\
\text { Statistical } \\
\text { Bulletin }\end{array}$ & $\begin{array}{l}\text { Monthly } \\
\text { Statistical } \\
\text { Bulletin }\end{array}$ & $\begin{array}{l}\text { Monthly } \\
\text { Statistical } \\
\text { Bulletin }\end{array}$ & $\begin{array}{l}\text { Monthly } \\
\text { Statistical } \\
\text { Bulletin }\end{array}$ & $\begin{array}{c}\text { Monthly } \\
\text { Statistical } \\
\text { Bulletin }\end{array}$ & $\begin{array}{l}\text { Monthly } \\
\text { Statistical } \\
\text { Bulletin }\end{array}$ & $\begin{array}{c}\text { Monthly } \\
\text { Statistical } \\
\text { Bulletin }\end{array}$ & $\begin{array}{c}\text { Monthly } \\
\text { Statistical } \\
\text { Bulletin }\end{array}$ & $\begin{array}{l}\text { Government } \\
\text { Finance } \\
\text { Bulletin }\end{array}$ & $\begin{array}{l}\text { Monthly } \\
\text { Statistical } \\
\text { Bulletin }\end{array}$ & $\begin{array}{c}\text { Government } \\
\text { Finance } \\
\text { Bulletin }\end{array}$ \\
\hline
\end{tabular}


Ms. Anne Krueger

Acting Managing Director

International Monetary Fund

Washington, DC 20431

U.S.A.

Dear Ms. Krueger,

1. The Government of Jordan has held discussions with Fund staff in the context of the second review of the program supported by the two-year Stand-By Arrangement (SBA) approved in July 2002. Based on these discussions, the attached Memorandum on Economic and Financial Policies (MEFP) reviews macroeconomic developments and implementation of structural policies in 2003 and describes the government's economic policies for 2004, cast in the context of a revised medium-term macroeconomic framework. Jordan's economic performance under the 2003 program was strong, exceeding expectations in many areas, and the policies for 2004 represent an appropriate response to the challenges emanating from the conflict in Iraq and are consistent with sound medium-term objectives. Accordingly, we hereby request completion of the second review under the SBA and a waiver of applicability for end-March 2004 performance criteria.

2. The Government of Jordan appreciates the financial and technical support provided by the Fund and intends to continue its adjustment and reform efforts as envisaged under the program supported by the SBA. In this regard, given Jordan's markedly improved balance of payments performance under the program and the substantial increase in its official foreign exchange reserves (well above the level envisaged under the program), we intend to treat the remainder of the SBA as precautionary.

3. We believe that the policies set forth in the attached MEFP are adequate to achieve the objectives of its program, but we will take any further measures that may become appropriate for this purpose. Jordan will consult with the Fund on the adoption of these measures, and in advance of revisions to the policies contained in the MEFP, in accordance with the Fund's policies on such consultation.

Very truly yours,

/s/

Mohammad Abu Hammour

Minister of Finance

Ministry of Finance

\author{
/s/ \\ Umayya Toukan \\ Governor \\ Central Bank of Jordan
}




\section{JORDAN}

\section{Memorandum on Economic and Financial Policies, 2003-04}

1. This memorandum reviews economic performance in 2003, updates the government's macroeconomic objectives in the context of a medium-term framework, and describes the government's economic policies for 2004.

\section{Developments Under the 2003 Program}

2. The economy appears to be recovering from the disruptions caused by the war in Iraq. Real GDP grew by 3.2 percent in 2003, after a sharp deceleration in the first half of the year because of the decline in exports to Iraq and the negative effects of the conflict on tourism and transportation. Growth in the second half of the year was mainly supported by a pick up in domestic demand, associated with increased confidence after the war, the recovery in bilateral trade with Iraq, and further growth of apparel exports from the Qualified Industrial Zones (QIZs), mainly to the United States. Inflation remained subdued at an annual average of 2.3 percent. The Amman Stock Exchange witnessed a boom after the war on expectations of a quick economic recovery and grew by about 54 percent in 2003. Unemployment, however, remains stubbornly high at 13.9 percent in part due to an increased participation rate.

3. All quantitative performance criteria on the fiscal deficit for end-June, endSeptember, and end-December 2003 were met by large margins. The overall fiscal balance for end-December, as measured from the financing side under the program, registered a deficit of JD 73 million (1.1 percent of GDP), compared to a deficit target of JD 175 million under the program (2.5 percent of GDP). About two-thirds of this large overperformance reflects a delay in settling certain payments to Iraq. Thus, the performance criterion for the fiscal deficit at end-December 2003 would still have been met with a comfortable margin, even if these payments were settled before the end of the year. Higher-than-programmed grant receipts allowed the government to increase spending substantially in support of domestic economic activity and at the same time reduce the fiscal deficit by almost 3 percent of GDP over the preceding year on a commitment basis. Budget revenues fell short of program projections, with higher tax revenues only partly offsetting a substantial shortfall in nontax revenues. In particular, general sales tax (GST) collections increased strongly, boosted by high import growth and improved revenue administration. In the last two months of 2003, the new government successfully limited current spending below programmed levels, despite significantly higher military spending reflecting the difficult security situation in the region and some payments to compensate economic sectors affected by the war in Iraq. In particular, the new Minister of Finance implemented spending cuts of JD 70 million committed but not executed by the previous government and issued a special order stopping all expenditure authorizations effected December 15, 2003. 
4. Notwithstanding the substantial reduction in the fiscal deficit, government and government-guaranteed debt increased by about 1 percentage point to $101 \frac{1}{2}$ percent of GDP at end-2003 as a result of valuation losses amounting to 6 percent of GDP associated with the depreciation of the U.S. dollar against other major currencies. The level of outstanding public sector debt, however, declined by 1 percentage point to 59.7 percent of GDP as a part of the valuation loss at the central government level were recovered through improved financial position of the CBJ and the continued generation of surplus by the Social Security Corporation (SSC). In line with its new fiscal funding strategy aimed at rebalancing the public debt portfolio in favor of domestic debt, the government also reduced external public debt by about 6 percent of GDP through the pre-payment of Brady Bonds and debt swaps transactions in December 2003, which will reduce external interest payments by $\$ 25$ million per year. The Ministry of Finance also issued five-year government bonds every quarter, the cumulative sum amounting to JD 500 million through end-December 2003, with the proceeds being used to prepay Jordan's stock of Par Brady Bonds.

5. The external current account registered a large surplus in 2003, reflecting a surge in grant receipts and underlying strength in the balance of payments. Total exports grew by 8.2 percent in 2003, despite the disruption and cancellation of export orders during the war in Iraq. Nontraditional exports fared particularly well, including textiles and apparel mainly destined to the U.S. market which now account for almost 30 percent of total domestic exports. Tourism receipts have started to recover due to an increase of visits from neighboring countries as well as higher official and business travel related to the situation in Iraq. Import growth rebounded strongly (10.8 percent), reflecting a pickup in domestic demand, higher oil prices, and an increase in re-export activity to Iraq. With grant receipts of more than $\$ 1.2$ billion (13 percent of GDP), the external current account surplus in 2003 was equivalent to 11.1 percent of GDP. Reflecting these positive developments, gross official reserves increased by $\$ 1.2$ billion to reach $\$ 4.7$ billion at end-December 2003 (equivalent to 9.7 months of imports of goods and non factor services), notwithstanding the early redemption of outstanding Brady Bonds (\$456 million in face value) in late 2003, financed by a drawdown of reserves of about $\$ 300$ million. The real effective exchange rate depreciated by 8.3 percent in 2003 , implying an increase in competitiveness of Jordanian exports.

6. Reflecting the strength of the balance of payments and the resulting large net foreign asset (NFA) inflows, monetary aggregates expanded at a healthy pace. Broad money grew by an annual rate of 11 percent in 2003. Private sector credit growth continued to be low (3.5 percent), as banks remain cautious due to the difficult regional situation. Lower interest rates have not yet had the expected impact on private sector credit due to structural issues in the economy. The large increase in NFA was only partly sterilized through an increase in bank deposits at the CBJ overnight window facility and bank holdings of certificates of deposit (CDs). As a result, reserve money grew at an annual rate of 20.7 percent. In December 2003, the CBJ further reduced the interest rate on the overnight window facility to 2 percent in order to improve the short-term yield curve. 
7. The recent Financial Sector Assessment Program (FSAP) missions reported that the banking system generally shows high capital ratios, liquidity, and profitability. However, poor governance affected negatively the asset quality of a few banks in the 1990s, resulting in high nonperforming loans and undercapitalization in those banks. The CBJ acted strongly to resolve this problem in the last two years, intervening in the case of two banks. An agreement was reached to restructure one of these banks in January 2004, entailing a change of management, the reconstitution of the bank's Board of Directors, and a limited liquidity support from the CBJ. In order to improve capitalization and corporate governance, the CBJ issued a regulation in August 2003 requiring banks to double their minimum capital requirements to JD 40 million over the next four years and introduced a minimum leverage ratio of 6 percent effective immediately. Over the last few months, the CBJ has been strengthening its bank supervision with a four pillar approach comprising: (i) a prompt corrective action framework that stipulates automatic penalties for violations of prudential regulations by banks, in line with the recommendations of the FSAP reports; (ii) a corporate governance handbook that delineates the appropriate separation of ownership and management in banks and sets standards for sound credit policies; (iii) an early warning system that flags unsafe and unsound practices, and the deterioration of the financial position of banks; and (iv) an electronic information sharing system with commercial banks. Jordan's regulatory and supervisory framework generally observes international standards and codes in banking, payments systems, securities, and insurance, reflecting the efforts to strengthen supervision in recent years.

8. Structural reforms are progressing as planned. The government sold half (26 percent) of its holdings in the Arab Potash Company (APC) to a Canadian corporation for JD 88 million in October 2003 net of all privatization costs. The government also started preparations for selling a majority stake in the electricity generation and distribution companies in 2004. A new gas pipeline between Egypt and Jordan has been completed under private sector initiative, which will be extended to Lebanon, Syria, and Turkey over the next few years. The government has embarked on an initiative to modernize the education system and improve its efficiency, under an education sector reform loan from the World Bank.

9. The pension reform has been completed. In January 2004, parliament approved the establishment of a medical committee in charge of approving military disability pensions, which is comprised of three civilian doctors appointed by the Ministry of Health and two military personnel. The maximum disability pension has also been capped at JD 500 per month and the formula for calculating disability benefits has been made more stringent. The so-called "four-year rule," which provided military officers with a pension of the next higher rank if they have served four or more years in their rank, has been eliminated.

10. Progress was made in establishing a unified tax administration. In line with Fund technical assistance recommendations, a unified revenue department was established in December 2003, encompassing the Income Tax and the Sales Tax Departments. The government appointed a director general in charge of the new department in January 2004. 
The merging of the operations of the Income Tax and Sales Tax Departments is proceeding with technical support from an Fund expert.

\section{Medium-Term Macroeconomic Framework AND POLICIES FOR 2004}

\section{A. Medium-Term Framework}

11. The government's central objective is to further raise living standards over the medium term through accelerated, private sector-led growth. As outlined in the MEFPs of June 2002 and June 2003, key elements of the medium-term strategy include a deepening of structural reforms, public investment in human capital and economic infrastructure, and continued implementation of sound macroeconomic policies, including further fiscal consolidation. The program aims to increase Jordan's real GDP growth rate to 6 percent per year over the medium term with a view to enabling the economy to create sufficient jobs to absorb the rapidly expanding labor force and reduce the unemployment rate from its current level of 13.9 percent. Macroeconomic policies will preserve and consolidate monetary stability and fiscal sustainability. Microeconomic policies, supported by the government's Plan for Social and Economic Transformation (PSET) under the National Social and Economic Action Plan (2004-06), will seek to bolster both the magnitude and the efficiency of private sector investment, through human resource development, improved public services provision, rural development, accelerated privatization, and the implementation of fiscal, administrative, regulatory, and judicial reforms. Because the PSET involves a large resource commitment through at least 2005 and will entail sizable recurrent outlays over a much longer period, the government is seeking multi-year grant financing from donors in order to ensure the achievement of its medium-term objectives. The operational aspects of PSET integration into the budget will be strengthened by merging the PSET in Chapter I of the 2005 budget along with other capital spending. The implementation of the PSET during the last two years will also be reviewed, in collaboration with the World Bank, to assess the quality of PSET spending and its impact on the economy.

12. The medium-term macroeconomic framework envisages a strong recovery in economic activity beginning in 2004, with real GDP growth accelerating to 6 percent per year on a sustainable basis over the medium term; continued moderate inflation of about 2 percent per year; a small surplus on average in the external current account; a secular decline in public external debt as a proportion of GDP and exports; and the maintenance of official international reserves equivalent to about eight months of prospective import cover. The private sector investments that will accrue as a result of privatization and the accelerated implementation of major projects will enhance prospects for growth.

13. The macroeconomic framework will be underpinned by a medium-term fiscal strategy aimed at sustained reductions in public debt and unfunded future pension liabilities. A sizable further debt reduction will be crucial for improving the quality of government expenditure, lowering real interest rates, and fostering investor confidence. Key elements of the fiscal 
strategy will include an acceleration of the privatization program; steps to broaden the GST and income tax bases; the elimination of the cross subsidies on petroleum products to offset the loss of Iraqi oil grants; and strengthening the long-term financial viability of the SSC. Despite an assumed steady decline in annual grant inflows, the overall fiscal deficit, including grants, is to be narrowed and stabilized at about 21/2 percent of GDP by 2007. Notwithstanding the recent setback due to valuation adjustments and lower-than-anticipated GDP growth, the ratio of government and government-guaranteed debt to GDP is still expected to fall by about 40 percentage points over the next six years, to about 65 percent by end-2009. This strategy is consistent with the 2001 Public Debt Management Law, which requires that the government reduce overall public debt to less than 80 percent of GDP by end-2006, with external public debt not exceeding 60 percent of GDP.

\section{B. Policies for 2004}

14. Economic policies for 2004 are designed to strengthen economic growth; maintain financial stability and a solid external reserve position through prudent demand management policy; and reduce further public indebtedness through continued fiscal consolidation. Real GDP growth is projected to rebound to 5 percent, somewhat lower than Jordan's full potential, reflecting the still uncertain security situation in Iraq, and the continued tensions in the West Bank and Gaza. Inflation is expected to increase somewhat because of upward adjustments in administered prices and certain tax rates, but will still remain moderate at about 3 percent. The balance of payments outlook is expected to remain strong despite the expected drop in the exceptional flow of external grants associated with the war in Iraq. As a result, the external current account is now expected to register a surplus of 5.3 percent of GDP, and official external reserves are programmed to remain at a comfortable level of about $\$ 4.7$ billion by end-2004.

\section{The 2004 fiscal program}

15. The 2004 budget, approved by parliament in February 2004, limits the overall budget deficit to 3.9 percent of GDP. The authorities will make their utmost effort to achieve this fiscal deficit target. However, additional payments that could not be settled in 2003 will require additional spending in 2004 over and above the budgeted level of at least 1 percent of GDP. We expect to cover these additional payments through higher grants beyond the budgeted level that are under active consideration but not yet fully secured. In the event, though, that these grants do not materialize, the budget deficit may need to be increased by up to 1 percent of GDP. Tax revenue is budgeted to increase by about 0.3 percent of GDP in 2004 compared to 2003 outturn, with higher GST receipts more than offsetting the decline in trade-related tax revenues brought about by the continuing liberalization of the trade regime. The expected revenue increase is supported by a package of revenue measures (yielding 1.6 percent of GDP on an annualized basis) and administrative reform. The tax measures, envisaged to be implemented shortly, include (with annualized revenue yields in parenthesis): (i) an increase in the basic GST rate by 2 percentage points to 15 percent $(0.6$ percent of GDP); (ii) an increase in excise taxes on alcohol and cigarettes ( 0.2 percent of GDP); and (iii) 
the doubling of taxes on mobile phone bill to 8 percent ( 0.1 percent of GDP). Nontax revenues are budgeted to remain broadly unchanged in relation to GDP, supported by an average increase in petroleum product prices of about 8 percent. Grants are projected to decline by $3 \frac{1}{2}$ percent of GDP, after the exceptional level of international support received in 2003, but would remain still high at 8.7 percent of GDP, based on existing commitments.

16. The government revenue efforts will also be supplemented by spending cuts equivalent to 3 percent of GDP, thus reversing the fiscal stimulus of 2003. Current expenditure is budgeted to decline by 2.1 percent of GDP compared to 2003, including about 1.1 percent of GDP in cuts envisaged in the budget. The areas where spending cuts would take place include: purchases of goods and services, transfers, and other nonproductive spending. Capital spending related to PSET execution is budgeted to be about 2.1 percent of GDP, in line with the projected availability of PSET grants. The implementation of the budget and the full utilization of privatization proceeds for debt-reduction purposes should enable us to reduce net government and government-guaranteed debt by $81 \frac{1}{2}$ percentage points of GDP to 93 percent of GDP by end-2004, based on current exchange rate assumptions.

17. The fiscal measures outlined above will be complemented by further structural reforms in the fiscal area. All government accounts have now been consolidated into a Treasury Single Account as of December 1, 2003 that allows for a timely and transparent monitoring of fiscal developments. The ministry of finance has also made significant progress in merging the Income Tax and the Sales Tax Departments (Income Tax Department (ITD) and Sales Tax Department (STD), respectively) to improve revenue collection. To this end, it has developed a comprehensive strategy to establish a unified tax administration with assistance from the Fund through the integration of the ITD and the STD. The proposed strategy would create a single function-based tax department with procedures based on the principles of self-assessment and taxpayer segmentation. The integration commenced in December 2003 with the establishment of a unified revenue department, encompassing the ITD and the STD under a single director general reporting to the Minister of Finance. In addition, in February 2004, the government set up a temporary integration project directorate with technical assistance from the Fund to oversee the development and implementation of the large and the medium taxpayer offices; the reform of small taxpayer administration; and the incremental establishment of an integrated head office. As the next step, by April 1, we will finalize the criteria for taxpayers who will be subject to the Large Taxpayer Office (LTO) administration.

\section{Monetary and financial policy}

18. Monetary policy will continue to support price stability. The current peg to the U.S. dollar has served Jordan well, bringing inflation down to industrial country levels and fostering confidence in the Jordanian dinar. Strong export growth in 2001-02, the recent sharp depreciation of the real effective exchange rate, and the rapid recovery in exports in the aftermath of the war in Iraq, provide assurance that competitiveness is adequate. The CBJ will continue to maintain a very comfortable international reserve position and stands ready 
to protect reserves and monetary stability through active liquidity management. The monetary program for 2004 is consistent with the objective of continued price stability and also allows for a substantial rebound in the rate of growth of bank credit to the domestic private sector. Broad money is projected to expand by about 8.5 percent, broadly in line with nominal GDP. The CBJ will limit the expansion of its net domestic assets so as to meet its international reserve target in a non-inflationary manner.

19. The government and the CBJ recognize the need to strengthen financial intermediation. The government will continue to issue long-term bonds to provide a benchmark for long-term lending by commercial banks. In addition, new laws were passed in the last few years to provide the legal frameworks for establishing and operating leasing companies, mutual funds, and credit rating agencies. Monetary conditions permitting, the $\mathrm{CBJ}$ will continue to improve on the structure of interest rates by increasing the spread between the overnight deposit rate and $\mathrm{CD}$ yields. This should revitalize the rather thin interbank market. Stronger competition and better management practices in commercial banks should also lead to a reduction in the spread between deposit and lending rates.

20. The CBJ plans to restructure the small bank under its temporary administration with new capital injection and with a new management and board, once the ongoing criminal proceedings are completed. The restructuring of this bank would probably require use of some public funds. In line with the prompt corrective action framework, the CBJ has reached agreements with undercapitalized banks on time-bound restructuring plans, will monitor closely these banks, and will be ready with corrective measures in the event of deviations from the agreed restructuring. The CBJ will continue with the implementation of the recommendations of the Fund safeguards assessment, which will further strengthen the control framework in the central bank. In this regard, the audit of the CBJ financial statements for 2003 will be done in accordance with international accounting standards and will include a second partner review by a reputable international accounting firm.

\section{Structural reform}

21. The government has embarked on a new fiscal funding strategy aimed at achieving a more balanced distribution between the local currency- and foreign currency-denominated components of the public debt. Sustained progress toward this goal would help absorb excess liquidity, develop a longer yield curve that would also provide a benchmark for lending to the domestic private sector, and reduce external indebtedness. The ministry of finance has been issuing five-year government bonds on a quarterly basis since end-2002. The government intends to continue with this strategy by developing a quarterly program for auctions of bonds of various maturities, with gross issuance targeted at levels consistent with a deepening of the domestic debt market. The authorities will explore the possibility of selling bonds to households directly under a national savings scheme. The funds thus raised will be used to reduce net external borrowings and, combined with the medium-term fiscal strategy outlined above, will reduce both the vulnerability of the public debt burden to exchange rate movements, and the level of excess liquidity in the domestic banking system. 
22. The government plans to accelerate and broaden the privatization program. As regards the power sector, the government has created separate generation, transmission, and distribution companies and has established an effective regulatory body for the industry. A new electricity law has been passed paving the way for the privatization of the sector through a new regulatory and tariff regime. With the completion of these steps, the stage has been set for the privatization of the generation and distribution companies in 2004. The government intends to sell a majority stake as well as management control in the Jordan Phosphate Mines Company to strategic investors and possibly an additional portion of the government's share in the Jordan Telecommunications Company. It will continue to privatize the remaining noncore units of the Royal Jordanian Airlines and will sell Jordan Post Company to a strategic partner. The fiscal program for 2004 estimates total privatization proceeds of about JD 300 million.

23. The government remains fully committed to pension reform. It has already shifted new military recruits to the SSC starting in January 2003, so as to reduce military pension liabilities to the budget over the long run. Parliament also ratified the associated temporary law in February 2004. The new tighter criteria for military disability pensions and the elimination of the "four-year rule" were implemented in March 2004. The government is also reviewing the draft actuarial review of the SSC and, once the report is finalized in 2004, it plans to implement the recommendations.

24. The government intends to improve the competitiveness of Jordanian exports by increasing efficiency in the transport sector. In addition, the handling capacity at the Aqaba port will be improved to avoid undue delays, following the increased activity of the port after the war in Iraq. The management of container handling at the port has also been privatized to improve efficiency and develop a medium-term strategic plan. The launch of the first independent power producer (IPP) project in the energy sector, the Samra power plant, fell through in November 2002 due to the difficult regional situation. The government has now created a separate public company to implement the project. The new company will seek to raise funds to implement the project mostly from the domestic banking sector without a government guarantee.

25. The loss of the Iraqi oil grant underlines the need to rationalize petroleum product prices and liberalize the domestic market for petroleum products. The government intends to eliminate the remaining subsidies on diesel, fuel oil, liquefied petroleum gas, and kerosene by end-2006 and to reduce the vulnerability of the budget to world oil price fluctuations. The government anticipates a multi-year transition period during which discretionary price adjustments will gradually eliminate the existing gap between domestic and international prices for the subsidized products. The price increases for energy products to be implemented in the context of the 2004 budget constitute a major step in that direction. Once the gaps between domestic and international prices have been closed, a symmetric automatic price adjustment mechanism based on international prices will be introduced. However, the full liberalization of the oil sector cannot be achieved until the exclusive concession rights of the Jordan Petroleum Refinery Company expire in 2008. 
26. The government and the CBJ are committed to meeting the Fund's Special Data Dissemination Standard within the next two to three years, and are implementing the recommendations of the Update to the Report on the Observation of Standards and CodesData Module in order to achieve this goal. In particular, the CBJ has already established a new balance of payments compilation division and has allocated additional positions to the new division. The $\mathrm{CBJ}$ also plans to start publishing its statistics according to the fifth edition of the BPM5 and the international reserve template by May 2004. A strategy to compile the international investment position in accordance with BPM5 will also be adopted by May 2004, with a view to commencing regular publication of these statistics within the following 12 months. To meet these targets, the CBJ is working with an Fund technical advisor on balance of payments statistics. In addition, the ministry of finance has requested technical assistance from the Fund to publish general government statistics by July 2004 .

\section{Program Monitoring}

27. Purchases under the SBA will be subject to observance of benchmarks and performance criteria, completion of program reviews, and a continuous performance criterion on the nonaccumulation of new external payment arrears. The third review of economic developments under the program will be conducted in June 2004.

28. Consistent with the discussion in Section II, quantitative performance criteria have been established for end-March 2004 and indicative targets have been established for endJune, as specified in Table 1. The performance criteria will apply to changes in net international reserves and net domestic assets of the CBJ; the overall fiscal deficit after grants; the stock of government and government-guaranteed short-term external debt (including that of the $\mathrm{CBJ}$ ); and the contracting or guaranteeing of new nonconcessional medium- and long-term external debt by the government and the CBJ. The quantitative performance criteria are defined in the attached Technical Memorandum of Understanding. Structural benchmarks are specified in Table 2. We will consult with Fund staff regarding developments that may affect external financing and grants, and any significant deviation from programmed levels will be a subject of program reviews.

Attachment:

Technical Memorandum of Understanding. 


\begin{tabular}{ccc} 
End-March & End-June \\
\hline 2004 & 2004 \\
Program & Program 1/ \\
\hline
\end{tabular}

(Cumulative flows from January 1, in millions of Jordanian dinars)

\section{Performance Criteria}

Net international reserves of the CBJ 2/

Net domestic assets of the CBJ 3/4/

Overall fiscal deficit after grants of the central government 5/ 6/ 7
(Cumulative flows from January 1, in millions of U.S. dollars)

Contracting or guaranteeing of new non-concessional medium-

Of which : with maturity of more than one year and up to and including five years

Non-accumulation of external payment arrears 8/

(Cumulative flows from January 1, in millions of Jordanian dinars)

\section{Memorandum item}

Programmed sum of foreign grants, net external financing of the budget (excluding project loans) and privatization

proceeds from abroad

Programmed foreign grants 6/9/

Source: Quarterly macroeconomic program.

1/ The targets for end-June 2004 are indicative targets.

2/ These floors will adjusted upward (downward) by the extent to which the actual sum of foreign grants and net external financing of the central government (excluding project-related loans and privatization proceeds from abroad) received during 2004 exceeds (falls short of) the levels specified above. This adjuster includes any net cost of prepaying external debt.

3/ These ceilings will be adjusted upward (downward) by the extent to which the floors on the net international reserves of the CBJ are adjusted downward (upward) due to shortfalls (excesses) in the sum of foreign grants and net external financing of the central government (excluding projectrelated loans and privatization proceeds from abroad) received during 2004, compared to the levels specified above. This adjuster includes any net cost of prepaying external debt.

4/ These ceilings will be adjusted downward (upward) by the extent to which the CBJ decreases (increases) reserve requirements on Jordanian dinar deposits of the banking system. The adjustment will equal the change in the required reserve ratio multiplied by the stock of deposits at licensed banks at the start of the month when the new reserve requirement ratio applies that are: (i) denominated in Jordanian dinars; and (ii) subject to reserve requirements.

5/ These ceilings will be adjusted upward by the extent to which expenditure associated with debt swaps with official bilateral creditors exceeds the amount specified above.

6/ These ceilings will be adjusted upward by the amount of recapitalization bonds at market interest rates placed by the government with the troubled banks discussed in Section II of the MEFP, up to a maximum amount of JD 100 million.

7/ These ceilings will be adjusted upward by the amount of the shortfall in grants received by the central government compared to the program targets, up to a maximum of JD 75 million.

8/ Continuous performance criterion.

9/ Excludes technical assistance grants channeled through the Ministry of Planning.

\section{CInternational Monetary Fund. Not for Redistribution}


Table 2. Structural Benchmarks

Under the Stand-By Arrangement, 2003

\section{Structural Benchmarks}

29. The CBJ will publish: (a) the balance of payments statistics of the CBJ according to the fifth edition of the Balance of Payments Manual of the Fund; and (b) the international reserve template according to Fund methodology (end-May 2004).

30. The government will issue a decree to create a single function-based revenue department by integrating the income tax and sales tax departments under a single director general reporting to the minister of finance. In addition, the ministry of finance will create a temporary integration project directorate to oversee development and implementation of the large and medium taxpayer offices; the reform of small taxpayer administration; and the incremental establishment of an integrated head office (end-March 2004) 


\section{INTERNATIONAL MONETARY FUND}

JORDAN

\section{Technical Memorandum of Understanding}

1. Under the Stand-By Arrangement, the government of Jordan is committed to implementing a financial program and a set of structural reforms. Progress in implementing the financial program will be monitored on the basis of quantitative performance criteria and indicative targets as set out in this memorandum, which is organized as follows: Section I specifies the quantitative performance criteria, indicative targets, and applicable adjusters. Section II specifies the content and frequency of the data to be provided for monitoring the program. Section III provides definitions of the principal concepts and financial variables.

\section{Quantitative Performance Criteria and Indicative Targets}

2. The quantitative performance criteria will consist of quarterly ceilings or floors on the following variables: (i) cumulative change (from December 31, 2003) in the net international reserves (NIR) of the Central Bank of Jordan (CBJ); (ii) cumulative change (from December 31, 2003) in the net domestic assets (NDA) of the CBJ; (iii) overall deficit after grants of the central government (as defined in Section III); (iv) outstanding stock of government and government-guaranteed short-term external debt with an initial maturity of up to and including one year; and (v) the contracting (from January 1, 2004) of new nonconcessional medium- and long-term government and government-guaranteed external debt with an initial maturity of more than one year, with a subceiling on debt with an initial maturity of up to and including five years. The floors and the ceilings applicable to the preceding variables will be monitored on the basis of the magnitudes specified in Table 1 of the MEFP.

\section{Adjusters to the performance criteria}

3. The performance criteria specified above will be adjusted as follows:

- $\quad$ The ceilings on the overall fiscal deficit after grants of the central government will be adjusted upward by the extent to which expenditures associated with debt swaps ${ }^{5}$ with official bilateral creditors exceed the amounts specified in Table 1 of the MEFP.

${ }^{5}$ Debt swaps entail a reduction of bilateral debt stock in exchange for government spending on specific development projects. 
- The ceilings on the overall fiscal deficit after grants of the central government will be adjusted upward by the amount of the shortfall in grants received by the central government compared to the programmed level as specified in Table 1 of the MEFP, up to a maximum JD 75 million.

- The ceilings on the overall fiscal deficit after grants of the central government will be adjusted upward by the amount of recapitalization bonds at market interest rates placed by the government with the troubled banks discussed in Section II of the MEFP, up to a maximum amount of JD 100 million.

- $\quad$ The floors on the net international reserves of the CBJ will be adjusted upward (downward) by the extent to which the actual sum of foreign grants and net external financing of the central government (excluding project-related loans and privatization proceeds from abroad) received during 2004 exceeds (falls short of) the levels specified in Table 1 of the MEFP.

- $\quad$ The ceilings on the net domestic assets of the CBJ will be adjusted upward (downward) by the extent to which the floors on the net international reserves of the $\mathrm{CBJ}$ are adjusted downward (upward) due to shortfalls (excesses) in the sum of foreign grants and net external financing of the central government (excluding project-related loans and privatization proceeds from abroad) received during 2004, compared to the levels specified in Table 1 of the MEFP.

- $\quad$ The ceilings on the net domestic assets of the CBJ will be adjusted downward (upward) by the extent to which the CBJ decreases (increases) reserve requirements on Jordanian dinar deposits of the banking system. The adjustment will equal the change in the required reserve ratio on Jordanian dinar deposits multiplied by the stock of Jordanian dinar deposits subject to reserve requirements programmed for the subsequent test dates. The stock of Jordanian dinar deposits subject to reserve requirements are programmed to be JD 5,505 million at end-March 2004 and JD 5,632 million at end-June 2004. During the program period, there will be no changes in the regulations defining the deposits that are subject to reserve requirements.

\section{Provision of Information to Fund StafF}

4. To permit the monitoring of developments under the program, the government will provide to Division B of the Middle East and Central Asia Department the information specified below and summarized in the list of reporting tables:

- $\quad$ CBJ foreign exchange reserves (weekly).

- Data on auctions of CDs by the CBJ (following each auction). 
- $\quad$ Monetary statistics, interest rates and consumer prices, and exports and imports (monthly).

- $\quad$ Summary budget operations, revenues, expenditures (including net advances), net domestic financing, balances in the government accounts with the CBJ and the commercial banks (including privatization accounts), swaps with official bilateral creditors and associated expenditures, the gross cost of debt buybacks and the proceeds from the sale of any collateral released (with accrued interest payments and receipts identified separately), and the receipt and use of privatization proceeds (monthly).

- The quarterly and annual accounts of the SSC (quarterly).

- $\quad$ Detailed foreign grants and loans received by the central government; foreign debt amortization and interest (including separately, cash payments, rescheduled and overdue amounts, excluding deferred debt service payments to the Arab development funds); any put or call options, collateral guarantees, warrants or similar derivative arrangements entered into by the government or the $\mathrm{CBJ}$; and the onlending operations of the government (monthly).

- $\quad$ Balance of payments (current and capital accounts) and external debt developments (quarterly).

- $\quad$ List of short,-medium, -and long-term public or publicly guaranteed external loans contracted during each quarter; identifying, for each loan: the creditor, the borrower, the amount and currency, the maturity and grace period, and interest rate arrangements (quarterly).

- New external arrears (if any) and total outstanding amount of arrears (quarterly), excluding deferred debt service payments to the Arab development funds.

- National accounts statistics (quarterly).

5. Weekly data and data on the central bank $\mathrm{CD}$ auctions should be sent to the Fund with a lag of no more than one week. Monthly and quarterly data should be sent within a period of no more than six weeks, except for external sector data, which should be sent within a period of no more than eight weeks, and quarterly national accounts statistics, which should be sent within a period of no more than three months. Any revisions to previously reported data should be communicated to the staff in the context of the regular updates.

\section{Definitions of the Principal Concepts and Variables}

6. The net international reserves of the CBJ consist of foreign exchange (foreign currency cash, deposits with foreign correspondents, and holdings of foreign securities, 
excluding any assets that are pledged or used as collateral), gold, the Fund reserve position, and SDRs, less the foreign liabilities of the CBJ (including to the Fund), less commercial banks' foreign currency deposits with the CBJ, and less any change in the CBJ's net foreign currency swap and forward positions from December 31, 2003. In addition, deposits received from foreign central banks or governments will be treated as liabilities in NIR, irrespective of maturity. Alternatively, the net international reserve (NIR) is equivalent to the national foreign asset (NFA) of the CBJ adjusted for outstanding purchases from the Fund and the bilateral accounts (net). ${ }^{6}$ Gold will be valued at the average price of JD 219.78 per fine troy ounce. The U.S. dollar value of foreign assets and liabilities will be converted into Jordanian dinars at the exchange rate of JD $1=$ US $\$ 1.4104$.

7. Reserve money is defined as the sum of: (i) currency in circulation (currency outside banks and commercial banks' cash in vaults); and (ii) nonremunerated deposits of the commercial banks in Jordanian dinars.

8. The net domestic assets of the CBJ are defined as reserve money less the sum of net international reserves and bilateral accounts. They include: (i) net claims on the central government; (ii) net claims on autonomous agencies with their own budgets; (iii) net claims on the SSC; (iv) net claims on municipalities and local governments; (v) net claims on nonfinancial public enterprises; (vi) gross claims on licensed commercial banks; (vii) claims on other financial institutions net of deposits; and (viii) other items (net); less: (ix) JDdenominated central bank CDs; (x) remunerated deposits of the licensed commercial banks in Jordanian dinars; and (xi) other remunerated deposits with the CBJ.

9. The central government is defined as the budgetary central government that is covered by the annual General Budgetary Law (GBL). It excludes the budgets of the 32 autonomous agencies, but includes all ministries and government departments, which operate in the context of the central authority system of the state.

10. Net external financing of the central government is defined as cash external debt disbursements, less scheduled external debt repayments; less gross cash payments made in relation to buybacks of debt and/or swaps of debt to official creditors net of: (i) accrued interest paid; and (ii) market value of any collateral released, excluding accrued interest receipts; plus exceptional external financing (rescheduled principal, interest, and accumulated external arrears, if any). The debts covered are debts of the central government (excluding off-budget military debts) and any foreign debts that are channeled through the central

\footnotetext{
${ }^{6}$ The definition of NIR implies that, for program monitoring purposes, disbursements and/or purchases from the Fund are to be recorded in the monetary accounts as external liabilities of the CBJ, rather than deposits of the government. Furthermore, commercial banks' foreign currency deposits with the CBJ are treated as foreign liabilities in the calculation of NIR and NFA.
} 
government to finance operations of the rest of the public sector (excluding off-budget onlending on loans that were contracted before January 1, 2002).

11. Net bank financing of the central government is defined as the cumulative change from December 31, 2003 in the banking system's claims in Jordanian dinars and in foreign currency on the central government (excluding holdings of Brady bonds), and net of the balances on government accounts with the CBJ and the commercial banks (including balances reflecting privatization receipts, but excluding deposits of UN compensation funds relating to damages incurred in the context of the Gulf war). Foreign currency claims will be converted into Jordanian dinars at the exchange rate of JD $1=\$ 1.4104$.

12. Net domestic nonbank financing of the central government is defined as central government borrowing from, less repayments to, the nonbank sector (including the nonfinancial public sector not covered by the general budget, and, specifically, the SSC), and the cumulative change (from December 31,2003) in the stocks of government securities held by nonbanks and in the float. Float consists of the value of checks issued by the government but not yet cashed by the beneficiaries.

13. The overall deficit after grants of the central government is defined as the sum of: (i) net external financing of the central government (including exceptional financing, i.e., rescheduled principal and interest payments); (ii) privatization receipts net of identified direct costs of privatization transferred during the relevant period to the central government accounts; (iii) net domestic bank financing of the central government; and (iv) net domestic nonbank financing of the central government. Profit transfers from the Jordan Investment Corporation (JIC) and small sales of JIC assets (not exceeding JD 5 million) will not be included in privatization receipts.

14. Government and government-guaranteed external debt covers all external debts incurred or guaranteed by government. "Debt" has the meaning set forth in point No. 9 of the Guidelines on Performance Criteria with Respect to Foreign Debt (Decision No. 12274(00/85), adopted August 24, 2000) and includes loans, bonds, suppliers' credits, leases, and other liabilities as further defined in the guidelines. Excluded are leases of real property by Jordanian embassies or other foreign representations, and any other lease from a nonresident for which the present value of all payments contracted during the period of the lease does not exceed JD 1 million. For program purposes, "government" includes the central government defined in paragraph 9 above, and government departments and official agencies which do not seek profit and whose budgets are issued independent of the GBL. The external debt will be expressed in U.S. dollar terms, with debts in currencies other than the U.S. dollar converted into U.S. dollars at the market rates of the respective currencies prevailing on December 31, 2003 as published in IFS.

15. Government and government-guaranteed short-term debt covers external debt defined in paragraph 14 above with an original maturity of up to and including one year, with 
the exception of normal import-related financing and instruments contracted after December 31, 2003 with put dates that occur within one year of the original contracting date.

\section{The performance criterion on contracting or guaranteeing of nonconcessional} government and government-guaranteed external debt applies not only to debt as defined in paragraph 14 above, but also to commitments contracted or guaranteed by government for which value has not been received. The performance criterion covers the contracting or guaranteeing by government or the CBJ of debt as defined in paragraph 14 above with an original maturity of more than one year and a grant element of less than 35 percent, using currency-specific discount rates based on the commercial interest rates (CIRRs) reported by the OECD. Discount rates for assessing the conditionality of loans with a maturity of at least 15 years or more will be based on the average CIRRs over the last 10 years. The assessment of conditionality for loans with maturities of less than 15 years will be based on the average CIRRs of the preceding six-month period. ${ }^{7}$ Aircraft leases contracted by Royal Jordanian Airlines are excluded.

17. Any variable that is mentioned herein for the purpose of monitoring a performance criterion and that is not explicitly defined, is defined in accordance with the Fund's standard statistical methodology, such as the GFS. For variables that are omitted from the Technical Memorandum of Understanding but that are relevant for program targets, the Jordanian authorities shall consult with the staff on the appropriate treatment based on the Fund's standard statistical methodology and program purposes.

\section{Attachment}

List of Reporting Tables.

\footnotetext{
${ }^{7}$ Margins will be added to CIRRs as follows: 75 basis points for loans with maturity of less than 15 years; 100 basis points for loans with maturity of 15 years or more and less than 20 years; 115 basis points for loans with maturity of 20 years or more and less than 30 years; and 125 basis points for loans with maturity of 30 years or more.
} 
List of Reporting Tables

\section{Fiscal Data}

F1. Government Domestic Revenues

F2. Government Expenditure and Net Lending

F3. Summary Fiscal Operations

F4. Balances of Government Accounts with the Banking System

F5. Foreign grants

F6. Foreign loans

F7. Net Lending to Public Entities

F8. Receipt and Use of Privatization Proceeds Fund

F9. Budgetary Expenditure Related to Debt Swaps with Official Creditors

\section{Monetary Data}

M1. Monetary Survey

M2 Balance Sheet of the Central Bank

M3. Consolidated Balance Sheet of Deposit Money Banks

M4. Selected Bi-Weekly Statistics

M5. Foreign Assets and Liabilities of the Central Bank of Jordan

M6. Off-balance Sheet Activities of the Central Bank of Jordan

\section{External Sector Data}

E1. Quarterly Data on the Balance of Payments

E2. Monthly Data on Exports -- Prices and Volumes

E3. Monthly Data on Imports -- Prices and Volumes

E4. Quarterly Data on the Services Balance

E5. Quarterly Data on External Debt Service

E6. Monthly Data on Outstanding and Newly Contracted External Debt

E7. Quarterly Data on Foreign Grants (BOP basis)
Ministry of Finance

Ministry of Finance

Ministry of Finance

Ministry of Finance

Ministry of Finance

Ministry of Finance

Ministry of Finance

Ministry of Finance

Ministry of Finance

Central Bank of Jordan

Central Bank of Jordan

Central Bank of Jordan

Central Bank of Jordan

Central Bank of Jordan

Central Bank of Jordan

Central Bank of Jordan

Central Bank of Jordan

Central Bank of Jordan

Central Bank of Jordan

Ministry of Finance

Ministry of Finance

Central Bank of Jordan
Monthly

Monthly

Monthly

Monthly

Monthly

Monthly

Monthly

Monthly

Monthly

Monthly

Monthly

Monthly

Monthly

Monthly

Monthly

Quarterly

Monthly

Monthly

Quarterly

Quarterly

Monthly

Quarterly
Six weeks or less Six weeks or less Six weeks or less Six weeks or less Six weeks or less Six weeks or less Six weeks or less Six weeks or less Six weeks or less

Six weeks or less Six weeks or less Six weeks or less Six weeks or less Six weeks or less Six weeks or less

Eight weeks or less Eight weeks or less Eight weeks or less Eight weeks or less Eight weeks or less Eight weeks or less

Eight weeks or less 


\section{Statement by the IMF Staff Representative \\ April 2, 2004}

This statement updates the information provided to the Executive Board in the staff report issued on March 17, 2004. The new information does not change the thrust of the staff appraisal.

Recent economic developments point to continued strong macroeconomic performance. Exports in the three months through January 2004 grew at an annual rate of 30 percent, spurred by a near doubling of exports of clothing and apparel. Imports grew at an annual rate of 18 percent during the same period. Revised estimates of the balance of payments for 2003 indicate a slightly higher current account surplus compared to the data presented in the staff report. General sales tax (GST) and income tax collections were strong through February 2004, leading to a budgetary surplus - excluding spending through nonbudgetary accounts of JD 117 million (1 $1 \frac{1}{2}$ percent of projected 2004 GDP). Broad money continued to expand at a healthy pace through January 2004 (13.5 percent year-on-year), reflecting strong demand for currency. Revised monetary data through end-2003 also show a somewhat higher expansion of broad money (12.4 percent year-on-year) compared to 11.0 percent presented in the staff report. The gross usable reserves of the CBJ declined by $\$ 237$ million since end2003 and stood at $\$ 4.5$ billion on March 25, 2004, reflecting the unfreezing of Iraqi government accounts held in Jordan and the timing of disbursements of grants, as envisaged under the program. The performance criterion on the net international reserves of the CBJ at end-March 2004 is expected to have been observed by a comfortable margin.

The authorities continued to make progress on policy implementation and structural reforms. Parliament approved the increase in the standard GST rate to 16 percent effective April 1, one percentage point higher than envisaged in the authorities' Memorandum on Economic and Financial Policies. In addition, the cabinet approved the extension of the GST to alcohol and tobacco, and an average increase of 9 percent in domestic petroleum product prices effective April 3. These measures should yield additional revenue equivalent to 2.2 percent of GDP on an annualized basis, which will help the authorities achieve the fiscal deficit target under the program. Parliament also ratified the temporary laws passed in 2003 on the taxation of interest income and the income withholding tax on importers. Finally, the cabinet approved the planned privatization of the electricity generation and distribution companies, which is expected to attract significant interest from investors. 


\section{Statement by A. Shakour Shaalan, Executive Director for Jordan April 2, 2004}

1. The authorities would like to express their thanks to Management and the Executive Board for their support to Jordan, and staff for their excellent work and helpful policy advice over the course of this program. Given the strong balance of payments position, the authorities intend to treat the remainder of the Stand-By Arrangement as precautionary.

2. The Jordanian economy has once again proved its resiliency to external shocks, thanks to its solid fundamentals and the swift response to mitigate the adverse impact of the war on macroeconomic stability and growth. Prudent macroeconomic policies, supported by the introduction of key structural reforms as well as generous aid from the international community, helped Jordan withstand the repercussions of the disruption of trade with Iraq during the war, the loss of the Iraqi oil grant, as well as the sharp decline in tourism and foreign investment. Underpinned by the strong recovery in exports following the end of the war, GDP growth remained healthy and exceeded population growth in 2003. Inflation was low and the external current account improved appreciably, allowing the central bank to accumulate sizeable foreign reserves. Performance under the program continued to be strong, with Jordan meeting all performance criteria and structural benchmarks, and the fiscal outturn outperformed the program target by a wide margin.

3. The outlook for the Jordanian economy is promising. With the recovery of trade with Iraq and the revival in tourism and investment, growth is expected to resume an upward trend in 2004. Over the medium term, the wide-ranging structural reforms undertaken over almost a decade and a half, and intensified in the past few years focusing on enhancing the investment climate, laid a solid foundation for Jordan to move to a higher and steadier growth trajectory. The authorities nonetheless realize that the reform agenda is still unfinished, and are determined to continue the reform effort after graduating from Fundsupported programs, in order to remove the remaining impediments to higher growth and a reduction in the still high unemployment. Their economic policy strategy for the period ahead focuses on preserving macroeconomic stability and bolstering productivity and competitiveness, including through improving infrastructure and human capital, further enhancing the legal and regulatory framework, speeding up the privatization process, and strengthening the financial system. A crucial component of this strategy is a fiscal framework that aims at achieving further fiscal consolidation and improving the structure of public finance, with a view to ensuring fiscal sustainability and a continuation of the reduction in public debt.

4. The fiscal overperformance, despite the difficult regional environment, attests to the authorities' commitment to fiscal consolidation. Expenditures during the last quarter were sufficiently tightened to offset part of the expansion in security outlays early in the year, compensation payments to sectors affected directly by the war, as well as capital expenditure to help temper the impact of the war on growth. Additionally, significant efforts were made in 2003 to lower the public debt and reduce its burden, including through the prepayment of the Brady bonds, but valuation losses equivalent to 6 percent of GDP arising from the 
depreciation of the dollar caused the level of the debt to edge up by 1 percentage point of GDP.

5. The 2004 budget contains important tax and expenditure measures consistent with the targeted budget deficit of 3.9 percent of GDP. Higher GST receipts are expected to more than offset trade liberalization-related revenue losses, and envisaged cuts in non-essential spending will amount to 3 percent of GDP. Reform measures aimed at achieving these targets have already been initiated. This week, Parliament approved an increase in the GST rate from 13 to 16 percent, an extension of the GST to alcohol and tobacco, and a 9 percent increase in petroleum product prices. The temporary tax laws passed in 2003 subjecting interest income to tax and imposing an income withholding tax on imports have been recently ratified by Parliament. The Ministry of Finance has unified the income tax and sales tax departments, and work on establishing large and medium taxpayer offices to increase the effectiveness of the new unified department is underway. In addition, expenditure control is being further strengthened and a unified treasury account has been established.

6. Over the medium term, reducing the public debt to comply with the limits specified in the Public Debt Law by 2006 is a paramount objective of the fiscal strategy. The authorities aim at further fiscal consolidation relying on durable fiscal measures, including through further broadening the tax base and eliminating the remaining subsidies on petroleum products. They will also continue to pursue an active public debt management strategy to reduce its level and improve its dynamics, particularly by balancing its composition in favor of local currency-denominated instruments. To reduce the public debt vulnerability to fluctuations in the value of the dollar, the authorities are exploring means to hedge against exchange rate fluctuations and are considering further diversification of foreign currency reserves in line with the currency composition of the external public debt.

7. Monetary policy has been geared to provide some stimulus to temper the slowdown in growth, while maintaining price stability and confidence in the dinar. Inflation remained low despite the impact of the depreciation of the dinar (which is effectively linked to the dollar) on import prices, and foreign exchange reserves reached a record high. The environment of tight fiscal stance and enhanced confidence, reflecting for the most part the strong track record of the central bank, provided scope for a monetary policy easing to boost domestic demand. The CBJ overnight window facility rate was reduced twice, bringing about some reduction in lending rates in the banking system. Going forward, monetary policy will continue to support price stability in the context of the fixed exchange rate framework. The central bank will continue its effort to enhance the effectiveness of monetary policy in line with the FSAP recommendation, including by further improving the structure of interest rates on its instruments and addressing the structural problems impeding flexibility of interest rates in the banking system. These efforts will benefit from the envisaged quarterly program to auction bonds with different maturities, which will go a long way in deepening the capital market and improving the yield curve.

8. The effective peg of the dinar to the US dollar has served Jordan well. For almost a decade since its adoption, Jordan has been able to maintain inflation at industrial country levels. Confidence in the dinar has strengthened, and capital flight and pressures on foreign currency reserves were virtually absent. Furthermore, Jordan's past experience clearly 
indicates that the economy is prone to shocks that are usually associated with short-lived uncertainties, and that the fixed exchange rate proved useful in insulating the economy from the adverse impact of these shocks. The authorities believe that a change in the exchange rate policy at this stage is not warranted and could be seen as a sign of weakness given the uncertainties arising from the current tense regional situation.

9. The recent FSAP mission confirmed that the banking system in Jordan is generally sound and well supervised. Most banks are profitable and well capitalized. This reflects the central bank's relentless effort over the past few years to strengthen the regulatory and supervisory framework in line with best international standards. This effort has been stepped up recently to address the remaining weaknesses identified by the FSAP mission. The central bank issued regulations to double the minimum capital requirement by 2007 and introduced a minimum leverage ratio of 6 percent. Measures have also been initiated to improve corporate governance and financial disclosure, and bank supervision has been significantly strengthened with the development of an early warning system and the adoption of a prompt corrective action framework. Furthermore, competition has been enhanced by licensing three foreign banks to operate in Jordan, which bodes well for the effort to reduce interest rate spreads and enhance financial intermediation.

10. The central bank was prompt in dealing with the few undercapitalized banks. One bank has been restructured, including through new capital injection by the shareholders and a strengthening of its management and board of directors, while the restructuring of the other undercapitalized banks is underway according to the agreed time-bound restructuring plan. In the meantime, the central bank is closely monitoring the financial positions of these banks and their compliance with prudential regulations. The authorities do not believe that there is any significant risk of moral hazard as a result of the restructuring process of the first bank, especially since the amount of liquidity support provided to the bank was modest and the original shareholders bore the largest share of restructuring burden. Furthermore, a prompt corrective action framework has been adopted and the authorities have made clear their determination to apply it strictly in order to avoid the use of public funds.

11. On other structural reforms, important pension reforms aimed at reducing long-term pressures on the budget have been undertaken. These included the tightening of military disability benefits and the shifting of the new military recruits to the Social Security Corporation (SSC). The authorities intend to strengthen the financial viability of the SSC drawing on the findings of the actuarial review to be finalized this year. Furthermore, significant strides were made in the privatization process, thereby supporting investment and reducing inefficiencies as well helping reduce the public debt. The government sold half its share in the Arab Potash Company, privatized the management of the container handling at the port, and approved the planned privatization of the electricity generation and distribution companies late this year. Plans are also in place to privatize other major public enterprises, including selling an additional portion of the government's share in the Jordan Telecommunication Company and the majority stake in the Jordan Phosphate Company. Proceeds from privatization will be used only for debt reduction operations while the Plan for Social and Economic Transformation, which used to be financed partly from privatization proceeds, will be financed exclusively from external grants. 
Press Release No. 04/71

FOR IMMEDIATE RELEASE

April 2, 2004
International Monetary Fund

Washington, D.C. 20431 USA

\section{IMF Executive Board Completes Second Review of Jordan's Stand-By Arrangement}

The Executive Board of the International Monetary Fund (IMF) completed today the second review of Jordan's performance under a two-year SDR 85.28 million (about US\$126.26 million) Stand-By Arrangement. The arrangement, which was approved on July 3, 2002 (see Press Release No. 02/31), is being treated by the Jordanian authorities as precautionary and is not intended to be drawn upon given the strength of Jordan's external position.

In completing the review, the Executive Board approved a waiver of applicability of the end-March 2004 performance criteria.

Following the Executive Board's discussion on Jordan, Anne Krueger, Acting Managing Director and Chair, issued the following statement:

"The Jordanian economy, supported by generous financial support from the international community, showed strong resilience in 2003, despite the negative effects of the war in Iraq. The authorities should be commended for their continued commitment to prudent macroeconomic policies and far-reaching structural reforms, which has resulted in strong export growth, low inflation, higher investment, and a surge in international reserves.

"The fiscal adjustment in 2003 is commendable, particularly as it came against the background of strong capital- and security-related spending pressures following the war in Iraq. Going forward, the authorities plan to sustain their fiscal adjustment efforts, accelerate privatization, and utilize privatization proceeds solely for debt reduction purposes, so as to meet the debt ceilings mandated for 2006 under the Public Debt Law.

"Substantial export growth, the stronger reserve position, and the positive balance of payments outlook suggest that the Jordanian economy remains competitive, and that the fixed exchange rate regime has served Jordan well.

"The banking sector in Jordan is basically sound, and the regulatory and supervisory framework generally observes international standards and codes in banking, payments systems, securities, and insurance. The authorities should effectively implement their new time-bound corrective action framework to deal swiftly with the remaining few undercapitalized banks. 
"The recently completed reforms of the military and the civil service pension systems were essential steps toward fiscal consolidation over the medium and long term. The improved economic outlook has enhanced the scope for accelerating the privatization program, and the recently launched privatization of the electricity sector is a welcome step in that regard.

"The authorities have demonstrated a strong commitment to prudent financial policies and a solid record of policy implementation. Given the strength of the external position, the authorities' intention not to make the purchase associated with the completion of this review is appropriate, and consistent with their intention to graduate from a series of Fund-supported programs following the completion of the current Stand-By Arrangement in July 2004," Ms. Krueger said. 


\section{INTERNATIONAL MONETARY FUND}

\section{IMF Concludes 2004 Article IV Consultation with Jordan}

On April 2, 2004, the Executive Board of the International Monetary Fund (IMF) concluded the Article IV consultation with Jordan. ${ }^{1}$

\section{Background}

Recent economic developments point to a recovery from the disruptions caused by the war in Iraq. Real GDP growth slowed down to 3 percent in the first nine months of 2003, due to the disruption of exports to Iraq and the negative effects of the conflict on tourism and transportation. Economic growth picked up to 3.5 percent in the fourth quarter of 2003, supported by a significant jump in exports in the last two months of 2003.

The recovery is being supported by a boom in export growth from the Qualified Industrial Zones, with exports to the United States growing by 56 percent over the last 12 months. A fiscal stimulus through higher public spending funded through grants also contributed to the recovery in domestic demand. Inflation remains subdued. The Amman Stock Exchange reached record highs in February 2004 on expectations of a positive outlook for the medium term. Unemployment, however, remains stubbornly high at 13.9 percent as result of the rapid growth of the labor force, in part due to an increased participation rate.

The fiscal deficit in 2003 was lower than the program limit, as spending overruns in the areas of defense and security and accelerated capital spending were offset by higher foreign grants. The overall deficit was JD 73 million (1.1 percent of period GDP), compared to a deficit target of JD 175 million under the program. Budgetary revenues

\footnotetext{
${ }^{1}$ Under Article IV of the IMF's Articles of Agreement, the IMF holds bilateral discussions with members, usually every year. A staff team visits the country, collects economic and financial information, and discusses with officials the country's economic developments and policies. On return to headquarters, the staff prepares a report, which forms the basis for discussion by the Executive Board. At the conclusion of the discussion, the Managing Director, as Chairman of the Board, summarizes the views of Executive Directors, and this summary is transmitted to the country's authorities.
} 
were somewhat lower than programmed, with higher tax revenues partly offsetting nontax revenue shortfalls. In particular, general sales tax collections increased strongly, boosted by high import growth and improved revenue administration. Capital spending was higher than programmed. Military spending and current transfers registered sizable overruns, reflecting the difficult geopolitical situation in the region and the need to compensate economic sectors adversely affected by the war in Iraq. Capital spending was accelerated by 39 percent in comparison with the preceding year in order to stimulate slack in the domestic demand in the aftermath of the Iraq war.

The external current account registered a large surplus in 2003, reflecting a surge in grant receipts and the underlying strength of the balance of payments. Exports grew by an annual rate of 8.2 percent, despite the disruption of exports to Iraq during the war. Nontraditional exports fared particularly well, including textiles and apparel mainly to the U.S. market. Re-export activity to Iraq rebounded strongly in the second half of the year. The strong export performance was only partly offset by faster-than-anticipated import growth (10.8 percent), reflecting a pickup in domestic demand and higher oil imports. Tourism receipts recovered in the second half due to an increase of regional visitors and official and business travels related to the situation in Iraq, while remittances grew by 4 percent. With grant receipts of almost US\$1.3 billion (13 percent of GDP), the external current account surplus for 2003 is estimated at 11.1 percent of GDP. Meanwhile, public sector loan disbursements were lower than programmed and net private capital flows registered a strong surplus of US\$694 million. As a result, gross official reserves increased by US $\$ 1.2$ billion to reach US $\$ 4.7$ billion, which is equivalent to about 10 months of prospective import cover. The real effective exchange rate depreciated by 8.3 percent in the 12 months to December 2003.

Monetary aggregates expanded at a strong pace, reflecting the strength of the balance of payments. Broad money grew by an annual rate of 12.4 percent in 2003, supported by a surge in the net foreign asset inflows, a large part of which was also channeled into Jordanian dinar deposits. Private sector credit growth continued to be low, as banks remain cautious and demand for credit was met mainly through a utilization of deposits. The large increase in the net foreign assets was only partly sterilized through an increase in bank deposits at the CBJ overnight window facility and bank holdings of CDs. As a result, reserve money grew by an annual rate of 20.7 percent.

Structural reforms are progressing as planned. The government sold half of its holdings (26 percent of total shares) in the Arab Potash Company along with transfer of management to a Canadian corporation for US\$124 million (net of privatization-related spending) in mid-October 2003. A management contract for the handling of the container terminal in the port of Aqaba was signed with a well-known port authority in February 2004. The government is also preparing the sale of majority stakes in the electricity generation and distribution companies in the first half of 2004. In the meantime, a new gas pipeline between Egypt and Jordan has been completed by the private sector on a build-own-operate basis and is expected to be extended to Lebanon, Syria, and Turkey. The government has embarked on a substantial improvement of the education system, with support from an education sector reform loan from the World Bank. 
Jordan's medium-term outlook remains positive. Trade liberalization and increased market access have set the stage for strong export-led growth over the medium-term. Export growth is expected to continue at about 6-8 percent per year, spurred by the free trade agreement with the United States and the Association Agreement with the European Union. Large private sector-led infrastructure projects, including in water, gas, and electricity generation, are likely to boost investment. Structural reforms, enhancement of health and educational standards, and poverty alleviation are likely to have a positive supply side impact on growth over the long term. Overall, growth is expected to reach 6 percent over the medium term. At the same time, inflation is likely to remain stable at about 2 percent per year. The external current account is expected to remain in surplus, while gross usable reserves of the CBJ remain at a comfortable level of about 7-8 months of prospective import cover.

\section{Executive Board Assessment}

Executive Directors welcomed the resilience of the Jordanian economy in 2003 in the face of the disruption caused by the war in Iraq. Following the war, exports have recovered and economic growth has picked up, the fiscal balance has improved, inflation has remained subdued, and international reserves have strengthened. The authorities' prudent macroeconomic policies and their steadfast implementation of structural measures aimed at transforming Jordan into a dynamic market economytogether with significant support from the international community-have contributed to these positive results. Directors welcomed the renewed commitment of the government formed in October 2003 to macroeconomic stability and structural reforms.

Directors welcomed the strong fiscal adjustment undertaken by the authorities in order to achieve the 2003 fiscal targets. They commended the timely implementation of the package of fiscal measures, which included a significant increase in general sales tax collection. Directors encouraged the authorities to continue with plans to adjust petroleum product prices so as to eliminate remaining subsidies.

Directors underlined the importance of continued fiscal consolidation to achieve the authorities' medium-term debt reduction strategy and to meet the debt ceilings mandated for 2006 under the Public Debt Law. The 2004 budget is an essential step in this direction. In light of the expected decline in external grants, Directors encouraged the authorities to sustain their fiscal adjustment efforts through further reforms of the tax system and its administration, improved expenditure management, and an acceleration of privatization. They welcomed the authorities' intention to utilize privatization proceeds solely for debt reduction purposes. They also welcomed the authorities' new fiscal funding strategy aimed at rebalancing the debt profile in favor of domestic debt. This strategy will significantly reduce the vulnerability of the debt profile to exchange rate movements while encouraging the deepening of the domestic financial system. Directors noted that monetary policy will continue to support the authorities' objective of price stability. Most Directors emphasized that the fixed exchange rate peg to the U.S. dollar continues to serve Jordan well and that competitiveness is adequate, as evidenced by the strong export performance. Some Directors considered that the 
authorities should continue building up the necessary institutional capacity to conduct an independent monetary policy.

Directors welcomed the generally positive conclusions of the Financial Sector Stability Assessment. They noted that, although the level of nonperforming loans is high, the banking system is basically sound. Following its recent strengthening, the regulatory and supervisory framework generally observes international standards and codes in banking, payments systems, securities, and insurance. Directors urged the authorities to deal swiftly with the few remaining undercapitalized banks on the basis of agreed time-bound restructuring plans. Directors looked forward to the timely approval of the anti-money laundering law.

Directors commended the authorities for progress in structural reforms, including trade liberalization. They noted that the recently completed reforms of the military and the civil service pension systems will strengthen fiscal consolidation over the medium and long term. The integration of the sales and income tax departments into a unified revenue department will also contribute by strengthening tax collections and enforcement. Directors welcomed the sale of the Arab Potash Company and the recent launch of the privatization of the electricity sector, which will help modernize the sector and attract private sector investment.

Directors welcomed the substantial progress that the authorities have made in strengthening the statistical system with a view to subscribing to the Fund's Special Data Dissemination Standard. They urged them to continue in their efforts to improve the quality of their statistical databases, including in the areas of balance of payments statistics and the international reserves template.

Public Information Notices (PINs) are issued, (i) at the request of a member country, following the conclusion of the Article IV consultation for countries seeking to make known the views of the IMF to the public. This action is intended to strengthen IMF surveillance over the economic policies of member countries by increasing the transparency of the IMF's assessment of these policies; and (ii) following policy discussions in the Executive Board at the decision of the Board. 


\section{Jordan: Selected Economic Indicators}

\begin{tabular}{|c|c|c|c|c|c|}
\hline & 2000 & 2001 & 2002 & 2003 & 200 \\
\hline & & & & I. Est. & Staff $P$ \\
\hline Real Sector & \multicolumn{5}{|c|}{ Changes in percent } \\
\hline Real GDP & 4.1 & 4.2 & 5.0 & 3.2 & 5. \\
\hline CPI (period average) & 0.7 & 1.8 & 1.8 & 2.3 & 3. \\
\hline Unemployment rate (in percent) & 13.7 & 14.7 & 15.3 & 13.9 & \\
\hline Gross national saving (in percent of GDP) & 22.9 & 22.2 & 27.0 & 33.3 & 28. \\
\hline Gross capital formation (in percent of GDP) & 22.2 & 22.2 & 22.5 & 22.3 & \\
\hline
\end{tabular}

\section{Public Finance}

Central government revenue and grants

Of which: grants

Central government expenditure and net lending 1/

Central government overall fiscal balance

Net public debt 2/

$\begin{array}{rrrrr}30.1 & 30.5 & 30.2 & 35.9 & 32.3 \\ 4.2 & 4.3 & 5.2 & 12.1 & 8.7 \\ 34.8 & 34.2 & 35.2 & 37.0 & 36.2 \\ -4.7 & -3.7 & -5.0 & -1.1 & -3.9 \\ 100.0 & 97.0 & 100.5 & 101.5 & 93.0\end{array}$

\section{Money and Credit}

Reserve Money

Changes in percent; unless otherwise indicated

Broad Money

$\begin{array}{rrrrr}7.1 & 3.3 & 7.0 & 20.7 & 8.9 \\ 10.2 & 5.8 & 7.0 & 12.4 & 8.5 \\ 4.5 & 11.5 & 3.2 & 3.5 & 12.0 \\ 6.0 & 3.9 & 3.0 & 2.1 & \ldots\end{array}$

Credit to the private sector

Interest rate on CBJ 3-month certificate of deposits

\section{Balance of Payments}

Merchandise exports

$\begin{array}{rrrrr}3.7 & 20.8 & 20.8 & 8.2 & 8.3 \\ 23.7 & 5.6 & 3.5 & 10.8 & 9.7 \\ 0.7 & 0.0 & 4.5 & 11.1 & 5.3\end{array}$

Merchandise imports

Current account balance (in percent of GDP)

Gross usable international reserves

(In millions of U.S. dollars)

(In months of import cover)

$\begin{array}{rrrrr}2,742 & 2,565 & 3,474 & 4,745 & 4,700 \\ 6.4 & 6.0 & 7.8 & 9.7 & 9.0\end{array}$

\section{Exchange Rates}

U.S. dollar per Jordanian dinar (end-period)

$\begin{array}{rrrr}1.4 & 1.4 & 1.4 & 1.4 \\ 2.9 & 6.6 & -7.3 & -8.3\end{array}$

Real effective exchange rate (end-period) $3 /$ 